\title{
ARTICLES
}

\section{Are Term Limits Undemocratic?}

\author{
Einer Elhauge $\dagger$
}

\section{INTRODUCTION: THE FALSE PARADOX OF TERM LIMITS}

The Supreme Court's decision in US Term Limits, Inc $v$ Thornton ${ }^{1}$ resolved the law regarding federal term limits but not their desirability. The decision makes this much clear: the Qualifications Clauses ${ }^{2}$ prohibit both Congress and the states from limiting the terms of federal legislators. Constitutional amendment is the only means left open. ${ }^{3}$ But the question that remains largely unilluminated is whether term limits are sound as a matter of political economy or democratic principle.

That question remains practically important to more than just scholars. The Qualifications Clauses do not apply to state legislators and governors, but many lawsuits claim that a fundamental conflict with democratic principles makes term limits on state officials unconstitutional under other clauses. ${ }^{4}$ Leaving

$\dagger$ Professor of Law, Harvard Law School. I am grateful for helpful comments on prior drafts or outlines of this work from Lucian Bebchuk, Jim Blumstein, Richard Fallon, Barry Friedman, Howell Jackson, Beth Garrett, Paul Gewirtz, Louis Kaplow, Ken Klee, John Lott, Richard Manning, Dan Meltzer, Eugene Mills, Martha Minow, Paul Mishkin, Henry Monaghan, Richard Parker, Nelson Polsby, Bob Rasmussen, Richard Revesz, Steve Shavell, Anne-Marie Slaughter, David Strauss, Peter Strauss, Steve Sugarman, Alex Tabarrok, Laurence Tribe, Martin Wattenberg, David Wilkins, and other participants at workshops at the Harvard Law School Colloquium, the Harvard Law \& Economics Workshop, and the Vanderbilt Law School Workshop.

1115 S Ct 1842 (1995).

2 US Const, Art I, § 2, cl 2; US Const, Art I, § 3, cl 3.

* US Term Limits, $115 \mathrm{~S}$ Ct at 1845, 1871.

+ See, for example, Nevada Judges Assn v Lau, 112 Nev 51, 910 P2d 898, 900 (1996) (Equal Protection and Due Process); Bates v Jones, 904 F Supp 1080, 1091 (N D Cal 1995) 
aside any legal issue, we need to know whether as a policy matter states should continue to press for term limits or rescind the ones they have and whether the answer differs for executive and legislative term limits. And other nations remain constitutionally unrestricted. Should they adopt term limits and does the answer differ depending on the voting system and on whether the limit applies to representatives to national government or to federations like the European Community? Nor is constitutional change beyond question for the United States. Should we press for a constitutional amendment allowing congressional term limits or for one repealing the limit on presidential terms? Should Presidents make approval of term limits a litmus test for future Supreme Court nominations? And there are questions of interest to scholars even if nothing practical turns on them. We want to know whether US Term Limits was correctly decided, and whether an ideal political process would include term limits, however impossible their adoption may be.

To say that the Court left the merits of term limits largely unilluminated is not to say it did not adopt a strong premise about them. It did: term limits struck the Court as patently undemocratic. As Part I discusses, the Court invoked traditional tools of text, framers' intent, history, and precedent, but it conceded ambiguity in those materials-an ambiguity it resolved at every turn with the assertion that term limits are undemocratic. This assertion borrowed partly from statements by our framers objecting that a legislative power to restrict who could run for office could produce elitist exclusions and legislative selfperpetuation. These are convincing objections to requirements that candidates be property owners, professionals, or members of the majority religion or party, which were the kind of restrictions the framers mainly considered. But the last thing one can say about term limits is that they help an elite or legislative majority to perpetuate itself in office. No, what really seemed to motivate the Court was a broader premise: that democratic principles give voters an unfettered right to vote for whomever they please.

This premise was hardly unique to the Court. The conventional wisdom among most academics and leading newspapers was that, whatever the constitutional ambiguity, term limits were clearly a bad idea. ${ }^{5}$ Doubtless this partly reflected the elite's

\footnotetext{
(First Amendment and Equal Protection).

s See, for example, Nelson W. Polsby, Constitutional Mischief: What's Wrong With Term Limitations, Am Prospect 40, 41 (Summer 1991); Gary S. Becker, Reforming Congress: Why Limiting Terms Won't Work, Bus Wk 18 (Aug 6, 1990); Kathleen M. Sullivan, Dueling Sovereignties: U.S. Term Limits, Inc. v. Thornton, 109 Harv L Rev 78, 109 (1995);
} 
distaste for what it perceived as a populist know-nothing movement based on the ridiculous premise that experience and expertise worsened legislative judgment. But the more fundamental and largely unchallenged objection was that term limits were undemocratic because they prevented voters from freely exercising their judgment to retain experienced representatives if voters wished. Term limits further seemed to have no redeeming prodemocratic virtue; if a majority of voters wanted to replace experienced incumbents with newcomers, they could do so without term limits. Just vote the bums out.

Indeed, no account of term limits can be satisfactory unless it explains an apparent paradox: why do the same voters who vote overwhelmingly for term limits also vote overwhelmingly to return their senior incumbents to office? At the same time that term limits were being passed in twenty-four states (with 70 percent support in some states), ${ }^{6}$ voters were generally returning 90 percent of state incumbents and up to 98 percent of federal incumbents who ran for reelection, the bulk of whom exceeded the term limits those voters had just approved. ${ }^{7}$ To many, the simultaneous votes for senior incumbents and term limits that would oust them are inconsistent, suggesting that votes for term limits reflected little more than an irrational temper tantrum at odds not only with democratic principles but with voters' own revealed preferences.

The paradox disappears, however, once we realize that there is no inconsistency between the two votes. As Part II shows, voters who wish to oust incumbents face a collective action problem. Incumbents by definition have more seniority than challengers, and this seniority gives them more legislative clout. Any individual district that ousts its incumbent is thus penalized by a smaller share of legislative power and governmental benefits unless the other districts also oust their incumbents. This penalty grows with the seniority of the incumbent and can coerce

Bruce E. Cain, The Varying Impact of Legislative Term Limits, in Bernard Grofman, ed, Legislative Term Limits: Public Choice Perspectives 21, 21 (Kluwer 1996) (Most political scientists oppose term limits.); David J. Olson, Term Limits Fail in Washington: The 1991 Battleground, in Gerald Benjamin and Michael J. Malbin, eds, Limiting Legislative Terms 65, 79, 89 (CQ 1992) (Virtually all Washington state newspapers opposed term limits.).

6 The twenty-four include the twenty-three listed in Scaring Mississippi Voters, Wall St J A18 (Oct 30, 1995), and New Hampshire, see NH Rev Stat Ann § 653:3-4 (Michie 1996).

7 See US Term Limits, 115 S Ct at 1912 (Thomas dissenting); Gerald Benjamin and Michael J. Malbin, Term Limits for Lawmakers: How to Start Thinking About a Proposal in Process, in Benjamin and Malbin, eds, Limiting Legislative Terms table B-2 at 293 (cited in note 5); Andrew R. Dick and John R. Lott, Jr., Reconciling voters' behavior with legislative term limits, $50 \mathrm{~J}$ Pub Econ 1, 2 \& n 3 (1993). 
districts to vote for incumbents whose ideological views the individual districts disfavor and who deliver pork that on balance harms all districts as a group. Each district might thus prefer ousting its senior legislator if others would do the same because that would reduce ideological divergence and pork levels without any district suffering a smaller share of governmental power and benefits. But because each individual district's vote on whether to reelect an incumbent does not affect whether other districts reelect theirs, each district rationally reelects its own senior legislator to get a greater share of governmental power and benefits. The districts will thus continue to reelect senior incumbents even if they would be better off collectively ousting them all. By ousting all legislators over a certain seniority level and reducing the penalty for replacing incumbents below that level, term limits can both decrease ideological slack and lessen overall pork. The result is not to fetter democratic preferences but to further them. With term limits, each district gets both ideological representation closer to its views and a lower overall amount of pork it prefers.

In addition, even if happy with the ideology of its representative, each district may desire to get rid of the senior representatives from other districts. Representatives from other districts cannot be reached through ordinary voting but can be reached through term limits. If the ideological and other political benefit each district derives from its senior representative is less than the political harm it suffers from other districts' senior representatives, each district can be made better off by agreeing to give up its senior representative if the other districts will give up theirs. This goal also presents a collective action problem: no district has incentives to individually oust its senior representative unless the others oust theirs, but each district can be made better off if all will oust their senior representatives collectively. Likewise, the goal seems prodemocratic, though with a significant difference: each district's individual representative may conform less to the district's democratic preferences, but the aggregate legislative representation comes closer to each district's preferences.

However, sometimes districts constituting a majority of the political jurisdiction may wish to oust the senior representatives of other districts even though those other districts are not made better off by the bargain. This presents less a collective action problem than a problem of the majority imposing its will on the minority. But, I will argue that furthering such majority preferences through term limits is also prodemocratic, especially since 
the underlying motivation is generally correcting the externalities the minority's representatives impose on the majority. ${ }^{8}$

The model developed in Part II does more than justify legislative term limits. By specifying the conditions supporting these justifications, it offers predictions and explanations about when and where term limits are likely to be popular. For example, as the foregoing suggests, districts differ. Even though sometimes all districts may favor term limits, they will not always be unanimous. The model explains which districts are likely to favor and oppose term limits. It further explains in which political jurisdictions and historical periods term limits are most likely to be popular. It explains why term limits are more popular in legislatures with district representation than in those with proportional representation. It predicts the forms term limits are likely to take when imposed by states on their federal officials. And it illuminates a seeming conundrum-why despite the seeming facial neutrality of legislative term limits, conservatives have been more uniformly in favor of them and liberal leaders have been split on their desirability.

But the analysis in Part II holds only for political representatives elected to a collective body through district-by-district voting. What explains the more established practice of imposing term limits for positions like President, governor, or mayor, ${ }^{9}$ where the entire political jurisdiction votes on each seat? Collective action problems cannot justify such term limits. Instead, as Part III shows, the justification is that voters may not be seeing the alternatives they prefer on the ballot because of entry barriers. Long-term incumbents have brandname advantages that create high barriers to political entry. By reducing these barriers, term limits can increase competition in legislative and executive races. The additional entry may present new candidates the districts prefer to incumbents but did not see on the ballot while entry barriers were high. More subtly, even if voters do not prefer the new candidates to the incumbents, greater competition can

See Part IV.A.2.

9 The United States Constitution imposes term limits on the President, see US Const, Amend XXII, $\S 1$, and many other countries do the same for their chief executives. See James D. Adams and Lawrence W. Kenny, Optimal Tenure of Elected Public Officials, 29 J L \& Econ 303, 314 \& n 21 (1986). Most states impose term limits on their governors. See Beth Garrett, Term Limitations and the Myth of the Citizen-Legislator, 81 Cornell L Rev 623, 630 n 15 (1996) (forty states); F. Paul Calamita, Comment, Solving the Voters' Dilemma: The Case for Legislative Term-Limitation, $8 \mathrm{~J}$ L \& Pol 559, 589 n 156 (1992) (collecting citations for thirty states). And 35 percent of major cities impose term limits on their officials. Mark P. Petracca and Kareen Moore O'Brien, The Experience with Municipal Term Limits in Orange County, California, in Grofman, ed, Legislative Term Limits 289, 289 (cited in note 5); Calamita, Comment, $8 \mathrm{~J} \mathrm{~L} \mathrm{\&} \mathrm{Pol} \mathrm{at} 561$. 
broaden and hone the issues debated and move incumbents to positions closer to those held by their electorates. Again, this analysis helps us understand not only the motivation for term limits but when and for which offices they are likely to seem attractive.

Nonetheless, the alleged paradox does dispose of many popular arguments for term limits, including claims that citizenlegislators are better than career politicians. Many argue that long legislative stints make legislators corrupt, arrogant, cynical, unprincipled, resistant to reform, sympathetic to special interest groups, and out-of-touch with their electorate. ${ }^{10}$ This would be avoided if representatives were like Cincinnatus, leaving their plows to serve only temporarily in the legislature and then returning to their farms. Much ink has been spilt debating whether term limits would produce such noble, fresh-minded, citizenlegislators or rather uninformed, easily manipulated amateurs. ${ }^{11}$ The ultimate question, stated in many different guises, is whether, at some point, further legislative experience on balance begins to worsen decisionmaking. That seems impossible to answer satisfactorily in the abstract. And some have persuasively argued that term limits might not even produce citizenlegislators but rather political careerists who move from one term-limited position to another. ${ }^{12}$ But the deeper problem is that, even if the proponents of citizen legislators are absolutely

${ }^{10}$ These were the arguments used during the constitutional debate about rotation, see US Term Limits, 115 S Ct at 1859 \& n 23; Part I.A.3, and by most current supporters of term limits. See, for example, Brief for the State Petitioner, US Term Limits (Nos 931456, 93-1828), $1994 \mathrm{WL} 444683$ at *4 (quoting Ark Const, Amend 73, preamble); George F. Will, Restoration: Congress, Term Limits and the Recovery of Deliberative Democracy 40-41 (Free Press 1992); Mark P. Petracca, Rotation in Office: The History of an Idea, in Benjamin and Malbin, eds, Limiting Legislative Terms 19, 20-28 (cited in note 5); Garrett, 81 Cornell L Rev 623 (cited in note 9) (collecting sources). Because these arguments prove to be unpersuasive justifications for term limits, it is not surprising that both the constitutional framers and the current Supreme Court had little difficulty rejecting term limits.

"Compare, for example, Polsby, Am Prospect at 40-42 (cited in note 5) (Term limits will produce uninformed amateurs who will be disproportionately old and rich persons needing no career.), with Will, Restoration at 9-10 (cited in note 10) (The careerism associated with long legislative tenures produces bad legislative decisions.).

${ }^{12}$ See Garrett, 81 Cornell L Rev at 656-57 (cited in note 9); Gerald Benjamin and Michael J. Malbin, Term Limits for Lawmakers: How to Start Thinking about a Proposal in Process, in Benjamin and Malbin, eds, Limiting Legislative Terms 3, 14-15 (cited in note 5). Nor is there good evidence that the backgrounds of legislators would change with high turnover. See Alexander Tabarrok, A Survey, Critique, and New Defense of Term Limits, 14 Cato J 333, 335-36 (1994) (noting that percentage of lawyers in Congress was just as high or higher when turnover was higher and that most legislator characteristics remain stable despite varying tenure levels); Linda L. Fowler, $A$ Comment on Competition and Careers, in Benjamin and Malbin, eds, Limiting Legislative Terms 181, 182 (cited in note 5) (same). 
right that legislative experience is bad and reduced by term limits, that still does not explain why we need term limits. If the only problem with the current system were that long legislative stints make incumbents unattractive representatives, voters could just vote against them. To explain and justify term limits, we need rationales that cannot be accomplished by ordinary voting. ${ }^{13}$

The collective action and entry barrier problems provide both that explanation and telling reasons to find term limits prodemocratic. Part IV shows that counterpoints exist, but there are certainly rational grounds for voters to think that term limits on balance enhance democratic representation. Given the theoretical uncertainty, democratic principles seem to mandate respect for the judgment of a voter majority choosing to adopt term limits. Indeed, since only the entry barrier problem applies to executives and both problems apply to legislators, ${ }^{14}$ the argument for term limits is stronger for Congress than for the President-an irony since the Constitution now prohibits term limits for Congress and mandates them for Presidents.

This Article will proceed on the definitional premise that more accurately reflecting the preferences of an electorate is prodemocratic. Some might quarrel with this definition or argue that, even if prodemocratic, accurate preference registration is not necessarily desirable. In particular, a Burkean might argue that ideological divergence between representatives and their electorates is more desirable or reflective of representative democracy. This is decidedly not the articulated premise of the Supreme Court or politically active opponents of term limits. Indeed, it is the supporters of term limits who argue that they are

\footnotetext{
${ }^{13}$ It is not, however, surprising to see such explanations offered for term limits. The flaws that people see in incumbent legislators are, after all, what would motivate supporters of term limits to want to replace all incumbents even under the public choice explanations I describe. Perhaps term limits supporters also intuited the public choice problems articulated here. The stated purpose of the California term limits initiative was, after all, to "restore ... competitive elections," to "encourage qualified candidates" to run, and to limit the "unfair incumbent advantages" that resulted in the "extremely high number of incumbents who are reelected." Cal Const, Art 4, § 1.5. Or perhaps they knew only that ousting noxious legislators through ordinary voting somehow did not work and decided to try something else. Whatever their subjective motivation, the justification for its expression through term limits must rest on grounds that could not be furthered by ordinary voting. That is, even if the claimed empirical paradox of the simultaneous votes for senior legislators and term limits could be otherwise explained, we would still have to face the claimed justificatory paradox that term limits cannot be justified unless they can accomplish something ordinary voting cannot.

" Consistent with this, the rate of incumbent reelection is generally far higher for legislators than for executives in both federal and state governments.
} 
more likely to produce Burkean representatives ${ }^{15}$ and the opponents who complain that term limits interfere with electorate preferences. I thus defer such alternative definitions of democracy until Part $I V$, which concludes that even a Burkean conception of democracy offers no sound grounds for condemning term limits as undemocratic. But the questions of what democracy is and whether it is desirable are perhaps too large and distracting for fruitful resolution here. I thus prefer to focus on the more concrete conclusion that term limits can enhance the accuracy with which the electorate's views are represented. That conclusion seems of interest no matter how one defines democracy and the social good. And in terms of the constitutional question, more accurately registering voter preferences surely seems a permissible goal for the electorate to further by enacting term limits.

\section{THE CONSTITUTIONAL QUESTION}

\section{A. The Ambiguity in the Legal Materials}

The legal question in US Term Limits was fairly straightforward. Do the Constitution's Qualifications Clauses, which require that all federal legislators be of a minimum age, citizens for some years, and state residents, implicitly prohibit states from imposing any additional qualifications on running for Congress? The evidence from the text, framers' intent, history, and precedent was surprisingly ambiguous.

\section{Constitutional text.}

The text for Representatives says simply that "No Person shall be a Representative who shall not have attained to the Age of twenty five Years, and been seven Years a Citizen of the United States, and who shall not, when elected, be an Inhabitant of that State in which he shall be chosen." 16 The text for Senators is the same except that the minimum age is thirty and the period of citizenship is nine years. ${ }^{17}$ The text does not say that states may impose additional qualifications. It does not say they may not. It is simply silent on the subject.

Nonetheless, the majority cited the canon of construction that expressio unius exclusio alterius est (the expression of one thing excludes others), reasoning that the listing of some qualifi-

\footnotetext{
${ }^{15}$ See Part IV.A.3.

${ }^{16}$ US Const, Art I, $\S 2, \mathrm{cl} 2$.

${ }^{17}$ US Const, Art I, $\S 3, \mathrm{cl} 3$.
} 
cations excludes any others. ${ }^{18}$ However, this canon, like many canons, has an equal and opposite counter-canon. ${ }^{19}$ Indeed, two counter-canons: (1) that courts should interpret ambiguity to further the purpose embodied in the included language, which often involves extending it by analogy to unincluded situations; and (2) that where lawmakers have shown they know how to exclude other things explicitly, their failure to do so implies an intent to allow inclusion. The underlying difficulty is that the failure to list other things may reflect simple inadvertence, a failure to consider those other things, or an inability to reach a consensus in favor of them rather than a considered consensus against them. That is particularly true here, where a failure to reach a consensus on other minimal qualifications that must be required for office hardly suggests a consensus that no other qualifications might reasonably be found or added.

But there were more particular problems in the case at hand. Even if one applied the expressio unius canon exclusively, the canon could be interpreted to mean that the inclusion of certain qualifications excluded the possibility that the Constitution itself imposes additional qualifications but not the possibility that Congress, let alone the states, may do so. The text, after all, could have stated that any person meeting the above three qualifications could be elected; instead it stated only that any person not meeting the three qualifications could not be elected. One might accordingly read the language's purpose as merely preventing Congress or the states from allowing the election of someone with lower qualifications, such as a twenty-one-year-old naturalized alien with one year of citizenship. ${ }^{20}$ If the clause sets only a floor, not a ceiling, then the expressio unius canon means only that the clause exhaustively lists all qualifications making up that floor.

Worse, even by itself the expressio unius canon cuts both ways, for the Constitution explicitly prohibits the imposition of a religious qualification for federal office. ${ }^{21}$ This implies that under the canon there are no other qualifications Congress or the states are forbidden to add. But the majority reasoned instead that various other provisions policing state involvement in aspects of

\footnotetext{
"US Term Limits, $115 \mathrm{~S} \mathrm{Ct}$ at $1850 \mathrm{n} 9$.

"See Karl N. Llewellyn, Remarks on the Theory of Appellate Decision and the Rules or Canons about How Statutes are to be Construed, 3 Vand L Rev 395, 401-06 (1950).

$\Rightarrow$ The example is not fanciful. Age and citizenship qualifications for state office at the time were in fact lower than the constitutional minimum, often allowing one to become a state legislator with as little as 21 years of age and one year of citizenship. See US Term Limits, $115 \mathrm{~S} \mathrm{Ct}$ at 1902 (Thomas dissenting).

${ }^{21}$ US Const, Art VI, cl 3.
} 
federal elections other than the qualifications of candidates evidenced a general purpose of restricting state interference that should be extended by analogy. ${ }^{22}$ That is, the Court applied a classic counter-canon to the expressio unius canon. Had the expressio unius canon been applied here it would have produced precisely the opposite conclusion: that the listing of the various provisions restricting state involvement in federal elections implied that there were no other restrictions on such state involvement, such as restrictions on state power to set qualifications for federal candidates. But the irony of using conflicting canons in the same opinion was apparently missed. Ultimately, the truth remains that all the text provides on the topic at hand is silence, and it is hard to derive anything meaningful from silence.

2. Textual editing decisions.

The majority found it significant that the Constitutional Convention rejected two proposals to give Congress the power to add qualifications. ${ }^{23}$ Further, the Convention rejected a form of term limits, a "rotation" provision requiring incumbent legislators to relinquish their seats for a term before running again. ${ }^{24}$

But it is always dangerous to reason from unadopted edits. Like unincluded text, they may indicate merely a failure to reach consensus in favor of the unadopted item, not a consensus against it. To be sure, the proposal of the edit means the issue was flagged, so that its nonadoption was not inadvertent. But the flagging of the issue cuts both ways, for if the lawmakers did not include language foreclosing the unadopted proposal, one could arguably infer a lack of consensus against it or maybe even an intent not to foreclose it.

Even if one views nonadoption as an intended ban on the proposal, that ban hardly determines the issue at hand. One might well object to giving federal legislators an unlimited power to impose property or other qualifications without opposing a state's power to impose term limits on its federal representatives. The concerns that qualifications might be used for elite or legis-

${ }^{22}$ The Court noted clauses: (1) requiring voter qualifications to be the same for federal and state office, (2) giving Congress the power to alter state time, place, and manner regulations of federal elections, (3) having congressional salaries set by federal law, and (4) allowing Congress to be the judge of the qualifications of its members. US Term Limits, $115 \mathrm{~S}$ Ct at 1857-59.

${ }^{23}$ Id at 1849. Under one proposal, Congress could have added a property owner qualification; under the other, any qualification it chose. Id.

${ }^{24}$ See id at $1859 \mathrm{n} 22$, citing Max Farrand, ed, 1 The Records of the Federal Convention of 178720,217 (Yale 2d ed 1937). 
lative self-perpetuation are arguably less serious when states rather than the federal government are the source of the qualifications. And those concerns certainly are less serious when the qualification takes the form of a bar on senior incumbents running for reelection.

Likewise, the refusal to enshrine rotation in the Constitution need only reflect an opposition to requiring a particular version of it for all time and all states. The particular version debated was, after all, quite draconian. It would have made all incumbents ineligible for reelection, thus maximizing last-period problems. ${ }^{25}$ One might well oppose such a one-consecutive-term limit without opposing modern term limits proposals.

Or perhaps the framers simply wanted to allow future electorates or individual states some flexibility on whether to impose rotation and what precise form to choose. Maintaining such flexibility seems like a wise decision, for term limits are far more attractive now than at the time of the constitutional framing. Turnover rates were higher then ${ }^{26}$ and of course the tenure of initial candidates for the new Congress was zero. Further, distributable governmental benefits per district were far lower since government, especially the federal government, spent and regulated far less. As subsequent analysis shows, such lower levels of prevailing seniority and governmental benefits directly lower collective action pressures to vote for ideologically divergent representatives. ${ }^{27}$ Since such pressures are largely what make legislative term limits attractive, it is hardly surprising to find less enthusiasm for term limits then than now.

Moreover, the dissent had an editing decision of its own. An early draft of the House of Representatives Qualifications Clause specified that "any person possessing these qualifications may be elected," but this language was later deleted. ${ }^{28}$ The deletion of language that would have made the qualifications exclusive, the US Term Limits dissent argued, made clear the clause was meant to set only a floor not a ceiling. ${ }^{29}$ The majority countered that this edit was equally consistent with the view that the deleted language was superfluous. ${ }^{30}$ True, but one could say the same about all the omissions, rejections, and nonadoptions the

¿ See Part IV.C.

${ }^{25}$ See Part II.C.2.

${ }^{2}$ See id and Appendix.

US Term Limits, $115 \mathrm{~S} \mathrm{Ct}$ at 1895 (Thomas dissenting), citing Farrand, ed, 2 Records at 139 (cited in note 24 ).

${ }^{24}$ US Term Limits, $115 \mathrm{~S}$ Ct at 1895 (Thomas dissenting).

${ }^{3}$ Id at 1860-61 n 27 (majority opinion). 
majority found significant-they are equally consistent with alternative interpretations.

The most likely explanation throughout is that the framers wanted to avoid language that might expose or provoke a conflict that could doom the whole constitutional enterprise. This tendency will be recognized by anyone who has ever served on a committee, and it is quite helpful in getting language approved by diverse bodies. Unfortunately, it offers no help on how to resolve the submerged conflict when it eventually arises.

\section{Framers' statements.}

In rejecting the proposals to add a power to add qualifications, some framers objected that such power would allow a current legislative majority to limit future elections to persons like themselves. ${ }^{31}$ As James Madison put it: "A Republic may be converted into an aristocracy or oligarchy as well by limiting the number capable of being elected, as the number authorised to elect."32 Further, in the ratification debates Madison rebutted the charge that the Constitution favored the wealthy by stating that, other than the qualifications listed in the Constitution, "No qualification of wealth, of birth, of religious faith, or of civil profession is permitted to fetter the judgment or disappoint the inclination of the people. ${ }^{33}$ Similarly, Alexander Hamilton responded, "The qualifications of the persons who may choose or be chosen ... are defined and fixed in the Constitution, and are unalterable by the legislature."34

But the context for this debate was defending against the charge that the Constitution imposed or allowed the federal imposition of unfair restrictions on who could run for office. The goal, after all, was getting ratification from states leery that ceding sovereignty to a powerful new federal entity might produce bad consequences. By their own terms the quotes betray this context, for Madison equated limits on who could be "elected" with those on who could "elect," and Hamilton asserted that the qualifications of who "may choose or be chosen" were both equally "fixed." Since states clearly could set qualifications

\footnotetext{
${ }^{31}$ Id at 1849-51, citing Farrand, ed, 2 Records at 250 (cited in note 24); US Term Limits, $115 \mathrm{~S} \mathrm{Ct}$ at 1856-57, citing Federalist 52 (Madison), in Clinton Rossiter, ed, The Federalist Papers 325, 325 (Mentor 1961); US Term Limits, $115 \mathrm{~S}$ Ct at 1862-63.

${ }^{32}$ Farrand, 2 Records at 250 (cited in note 24).

${ }^{33}$ Federalist 57 (Madison), in Rossiter, ed, Federalist Papers 350, 351 (cited in note 31).

${ }^{34}$ Federalist 60 (Hamilton), in Rossiter, ed, Federalist Papers at 371 (cited in note 31 ).
} 
for federal voters under explicit constitutional authority ${ }^{35}$ the quotes seem to concede an equal role for states to add qualifications for candidates. The statements could thus be read as meaning only that the Constitution and federal legislature did not fetter the judgment of the people, not that the people of states could not fetter their own judgment. Both Madison and Hamilton were, after all, focused on allaying fears that the new federal government would establish a tyranny by restricting who could run for office, not on allaying fears that states might misuse a power to restrict who could run for office that the states already possessed over both their own legislators and their representatives to the Federal Congress under the Articles of Confederation.

Further, as the Court noted repeatedly, the framers' major concern was that an unlimited power to add qualifications would allow a current elite or legislative majority to entrench itself and form a new "aristocracy or oligarchy." ${ }^{36}$ That is, the concern was that limits on who could run for office would diminish voters' "capacity to displace incumbents in favor of the representatives of a recently coalesced majority. ${ }^{\prime 37}$ But this capacity is not diminished by term limits-it is enhanced with a vengeance. The objection to term limits is not that they prevent voters from displacing incumbents but that they prevent voters from retaining them, and there is no evidence the framers shared the latter concern. To the contrary, James Madison, whose quotes the Court made Exhibit A for its interpretation, favored term limits on the merits; the Virginia Plan he forwarded to the Constitutional Convention would have required each House member to leave office after one term. ${ }^{38}$

Moreover, the dissent could cite its own Founding FatherThomas Jefferson. Unlike Madison and Hamilton, Jefferson did directly address the question whether states could add qualifications for federal candidates and concluded they could. ${ }^{39}$ Jefferson

"The Constitution sets the qualifications of voters for federal office equal to whatever qualifications states impose on voters for the most numerous branch of the state legislature. US Const, Art I, \$2, cl 1. See also US Term Limits, $115 \mathrm{~S} \mathrm{Ct}$ at 1856-57.

$\because$ US Term Limits, 115 S Ct at 1848-50 \& n 10, 1869, citing Farrand, ed, 2 Records at 250 (cited in note 24) (statement of Madison).

${ }^{37}$ Laurence H. Tribe, American Constitutional Law $\S 13-18$ at 1097 (Foundation 2d ed 1988). See also Parts II.A.3, II.B.1, and II.B.2.

"See Stephen C. Erickson, James Madison: Term Limits Radical the Father of Constitution's Solution to Congressional Career-ism, 4 Term Limits Outlook Series No 3 (Oct 1995).

${ }^{9}$ US Term Limits, $115 \mathrm{~S}$ Ct at $1860 \mathrm{n} 24$; id at 1888-89 (Thomas dissenting), citing Letter of December 20, 1787, from Thomas Jefferson to James Madison, in Andrew Lipscomb, ed, 6 The Writings of Thomas Jefferson 385, 389 (Jefferson Memorial Assn 1905). 
conceded this was "one of the doubtful questions on which honest men may differ, ${ }^{\prime 40}$ but this merely highlights Jefferson's judicious temperament, for any fair-minded person would find the matter debatable. ${ }^{41}$ In any event, when one side has Madison and Hamilton supportive on a related point and the other side has Jefferson supportive on the exact point but conceding its ambiguity, perhaps it is time to call a draw in the battle of Founding Father quotes.

Finally, the majority relied on an absence of statements. The recorded debate about the Constitution's failure to impose rotation contained no statement that the states themselves could impose rotation on their own federal representatives. ${ }^{42}$ Relying on an absence of recorded statements is always perilous. The absence may reflect only the record's incompleteness, especially given the fragmentary nature of the record at issue..$^{43}$ And any absence of statements seems equally likely to indicate that everyone assumed it was understood the states could adopt rotation as to indicate the opposite. After all, the record is also devoid of statements that the states could not adopt rotation for their own federal representatives. ${ }^{44}$ True, one might have thought that ratification supporters, responding to complaints about the lack of constitutional rotation, would have tried to blunt the complaint by pointing out that states could impose rotation if they thought states could. But one would also have thought that rotation proponents would have argued that a constitutional provision was the only way to get rotation if they thought states could not impose it. Perhaps neither side wanted to concede the point

${ }^{40}$ US Term Limits, $115 \mathrm{~S} \mathrm{Ct}$ at $1860 \mathrm{n} 24$ (majority opinion); id at $1889 \mathrm{n} 14$ (Thomas dissenting), citing Letter of January 31, 1814, from Thomas Jefferson to Joseph Cabell, in Lipscomb, ed, 14 Jefferson at 82, 83 (cited in note 39).

${ }^{4}$ Since the statement that honest men may come to differing views came in a letter to someone who held the opposing view, it may also have indicated simple politeness. See Letter of January 31, 1814, from Jefferson to Cabell, in Lipscomb, ed, 14 Jefferson at 8385 (cited in note 39).

${ }^{42}$ See US Term Limits, $115 \mathrm{~S} \mathrm{Ct}$ at 1860 . The Court also relied on statements by Hamilton and Robert Livingston against a rotation requirement. Id. However, their context of defending the Constitution's failure to impose rotation deprives the statements of any clear intent to deny states' ability to try rotation or other forms of term limits. In addition, the particular term limits proposal they were opposing would have required U.S. Senators alone to leave office after each six-year term, which not only targeted the very chamber of Congress meant to provide the most stability but also meant that all Senators would always be in their final terms. See Michael J. Malbin, Federalists v. Antifederalists: The Term-Limitation Debate at the Founding, in Benjamin and Malbin, eds, Limiting Legislative Terms 53, 55, 57-61 (cited in note 5). See also Part IV.C (discussing final period problem).

${ }^{43}$ US Term Limits, $115 \mathrm{~S} \mathrm{Ct}$ at 1901 (Thomas dissenting).

"Id. 
on state authority, nor wanted to blunt its own position on ratification by announcing its secretly preferred position on state authority, leaving the matter for another day.

Whatever the general wisdom of relying on an absence of statements, public choice theory provides an especially powerful reason not to rely on it here. Collective action problems made states unlikely to adopt rotation individually however much they might desire rotation collectively, for any states that imposed rotation would have less influence in the national legislature than other states with long-time uninterrupted representation. ${ }^{45}$ It was thus completely rational for all debaters to ignore the unrealistic possibility of individual states adopting rotation for their federal officials even while they were hotly debating whether the Constitution should collectively adopt rotation for all states.

For the same reason, it is unsurprising that, despite the widespread popularity of rotation at the time, no state in the early post-Constitution period independently imposed rotation on its federal representatives. ${ }^{46}$ The Court thus erred in concluding that the states' failure to try to rotate their representatives to Congress indicated that the states must have thought the Constitution prohibited rotational term limits. ${ }^{47}$ More likely it indicated the collective action problems with such individual state adoption. Consistent with this explanation, the one state that still had federal term limits in 1788 rescinded them in 1790 , just in time to avoid losing legislative seniority when no other state followed suit with their own term limits. ${ }^{48}$ Furthermore, states did impose various other qualifications on their federal representatives, as the next section shows.

\footnotetext{
* See Part II. For an explanation of how the recent term limit movement endeavored to overcome a similar collective action problem with state-imposed term limits on federal legislators, see Part II.D. Because rotation ousts all incumbents at the end of the current term, it would have been much more difficult to organize such concerted behavior among states. The motivation was also likely weaker at the time given lower levels of legislative tenure and distributable governmental benefits. See Parts II.A.2; II.C.2.

${ }^{4}$ See US Term Limits, $115 \mathrm{~S} \mathrm{Ct}$ at 1865-66. Various states did impose rotation on their representatives under the Articles of Confederation, but they faced no collective action problem because the Articles imposed rotation on all congressmen. See Edmund Cody Burnett, The Continental Congress 250 (MacMillan 1941).

${ }^{47}$ US Term Limits, $115 \mathrm{~S} \mathrm{Ct}$ at 1866.

4x Compare $\mathrm{Pa}$ Const of 1776, $\S 11$, in Francis Newton Thorpe, ed, 5 The Federal and State Constitutions 3085 (Hein 1993), with Pa Const of 1790, in id at 3092-3103. See Brief for State Petitioner in US Term Limits, 1994 WL 444683 at *14 \& n 14; Brief for Petitioner in US Term Limits, 1994 WL 444704 at *26 \& n 32. See also Denboer and Jenner, eds, 1 Documentary History of the First Federal Election, 1788-1790 229-30 (1984).
} 
4. Practice around the time of the framing.

The practice and law before the adoption of the Constitution can provide background norms helpful in interpreting what the framers may have meant or been thinking about. Practice immediately after the Constitution's adoption helps us understand how contemporaneous parties understood its terms at the time. Unfortunately, neither are very helpful here.

a) Prior practice. The Court stressed that the Constitution was enacted just after the resolution of a related British controversy. The British Parliament had for years refused to seat John Wilkes, who had been convicted of seditious libel for criticizing a peace treaty with France. After several reelections and exclusions, Parliament finally relented, allowing the voters to choose their own representative. ${ }^{49}$ But such exclusions obviously raise the concern of a current legislative majority manipulating charges to exclude political opponents and thus perpetuate itself in office. Thus, even assuming the constitutional framers wished to embody this concern, it has no bearing on term limits, a rule adopted by the voters themselves that prospectively excludes only legislators with long incumbencies. In any event, the English rule barred only exclusions for misconduct not covered by existing qualifications, not the promulgation of new, prospectively-applied qualifications by Parliament. ${ }^{50}$

Moreover, if one were to look to pre-Constitution rules and practices, the more relevant place to look would be in America. And here there was no doubt that states could add qualifications not only for state legislators but for the state's federal representatives to Congress under the Articles of Confederation. ${ }^{51}$ Still, it is not clear which way this cuts. Perhaps it shows the states assumed the same practice would continue. But one might also think that it means states would have realized the Constitution failed to give such authority and would have raised objections if they had any.

b) Early post-Constitution practice. Was the Constitution understood to change states' prior practice and prohibit the addition of qualifications? The answer is unclear. Several states did impose additional qualifications in their first laws governing elections to the new Congress. The old Pennsylvania Constitution continued to impose term limits on its congressional representa-

${ }^{49}$ See US Term Limits, $115 \mathrm{~S} \mathrm{Ct}$ at 1848. (1969).

${ }^{50}$ Id at $1894 \mathrm{n} 18$ (Thomas dissenting); Powell v McCormack, 395 US 486, 528-29

"US Term Limits, $115 \mathrm{~S} \mathrm{Ct}$ at $1894 \mathrm{n} 18$ (Thomas dissenting). 
tives, ${ }^{52}$ Virginia required its congressmen to be property owners, five states required federal representatives to be residents of their districts, and three states required federal representatives to have been residents for at least a year. ${ }^{53}$ The Qualifications Clauses not only imposed no property requirement but also required residency only in the state "when elected" and thus imposed no district residency or duration requirement either. ${ }^{54}$ Apparently these states thought adding qualifications was constitutional, and the record suggests state legislators faced and rejected constitutional objections. ${ }^{55}$

But the Court stressed that a larger number of states did not impose any additional qualifications, including many states that retained property ownership requirements for state legislators. ${ }^{56}$ Moreover, the Court noted that state practice was unreliable since states are predictably biased in favor of state power. ${ }^{57} \mathrm{It}$ also dismissed later state laws prohibiting persons like felons from running for office, finding them too removed in time from the constitutional framing. ${ }^{58}$

Congress's early practice was likewise ultimately inconclusive. In 1807, Congress considered whether to seat William McCreery, who allegedly did not reside in his district, as a state statute required. ${ }^{59}$ The relevant House committee report concluded that state legislatures lacked authority to add any qualifications to those the Constitution sets forth. ${ }^{60}$ But the committee's constitutional interpretation was hotly contested both inside the committee and on the House floor. So contested that, after four

${ }^{52}$ See note 48 and accompanying text.

${ }^{53}$ See US Term Limits, $115 \mathrm{~S}$ Ct at 1864-65; id at 1903-04 (Thomas dissenting).

$\approx$ See US Const, Art I, $\$ 2$, cl 2; US Const, Art I, § 3, cl 3 .

"See US Term Limits, $115 \mathrm{~S} \mathrm{Ct}$ at 1904-05 \& nn 32-34 (Thomas dissenting).

Id at 1864-65 \& $\mathrm{n} 34,1866 \mathrm{n} 41$ (majority opinion). Of course, these states may have concluded that: (1) property qualifications for federal candidates were less necessary or desirable than for candidates to the state legislature, where it was more plausible paupers would run; or (2) any benefits of imposing such qualifications on federal candidates were not worth the risk of constitutional challenge even if the states did not agree with the grounds for such a challenge. See id at 1907-08 n 37 (Thomas dissenting).

ir Id at 1864, $1866 \mathrm{n} 41$ (majority opinion).

** Id at $1866 \mathrm{n} 41$. See also id at 1909 (Thomas dissenting) (noting state laws disqualifying federal candidates who are prisoners, mental incompetents, convicted of vote fraud, or unqualified to vote).

Id Id 1861 (majority opinion); id at 1908-09 (Thomas dissenting). The fact that no such controversy arose in the first twenty years after the Constitution suggests previously widespread acquiescence in the district-residency and property-ownership qualifications imposed by some states. Of course, such acquiescence may not have indicated constitutional agreement but rather the impracticality of challenging the requirement and winning from an outside district or without property.

Id at 1908 (Thomas dissenting), citing 17 Annals of Congress 871 (Gales and Seaton 1852). 
days of debate, the House voted to recommit the issue to the committee, which thereupon excised all constitutional interpretations from its report and focused solely on whether McCreery in fact satisfied the residency requirement. The House then voted to seat McCreery, but deliberately refused to take any position on the constitutional issue, rejecting overwhelmingly both a resolution that McCreery had the qualifications imposed by his state and a resolution that he needed only the ones listed in the Qualifications Clause. ${ }^{61}$ If all this indicates anything, it is that the early Congress found the matter quite uncertain, as it was. Other congressional examples were less equivocal but came long after the Constitution was adopted ${ }^{62}$ and were thus too late to reflect the original understanding of the Constitution.

In short, congressional practice is not dispositive for reasons parallel to those that the Court used to dismiss state practice. It is equivocal, comes from a source one would expect to have a biased (here, relatively narrow) view of state authority, and much of it came too late to bear on the original understanding.

\section{Precedent.}

The majority relied heavily on Powell $v$ McCormack, ${ }^{63}$ which invalidated a House decision to exclude a representative allegedly guilty of diverting House funds. The Powell decision reasoned that Congress had no authority to add to the qualifications set forth in the Constitution. ${ }^{64}$

The dissent conceded that Powell correctly barred congressionally enacted term limits. ${ }^{65}$ Instead the dissent stressed, as the majority acknowledged ${ }^{66}$ that (notwithstanding some over-

61 US Term Limits, $115 \mathrm{~S} \mathrm{Ct}$ at 1908 (Thomas dissenting), citing 17 Annals at 927-47 (cited in note 60). Moreover, some of the support for striking down the state statute came from those who thought a state legislature could not add qualifications because that power rested with the people of the state acting by convention. See Roderick M. Hills, Jr., A Defense of State Constitutional Limits on Federal Congressional Terms, $53 \mathrm{U}$ Pitt L Rev 97, 125-27 (1991). This position would not justify striking down qualifications added to the state constitution by popular initiative, as almost all modern legislative term limits were.

${ }^{62}$ See US Term Limits, $115 \mathrm{~S}$ Ct at 1862 (majority opinion).

${ }^{\infty} 395$ US 486 (1969).

${ }^{\circ}$ Id at $522,532,550$.

* US Term Limits, $115 \mathrm{~S} \mathrm{Ct}$ at 1889 (Thomas dissenting).

${ }^{60}$ Id at 1890; id at 1852 (majority opinion). Indeed, arguably Powell can stand only for the proposition that a single house of Congress cannot impose additional qualifications. Reference to Congress being unable to do the same are technically dicta, and an Act of Congress prospectively adding disqualifications raises less concern about opportunistic exclusions. See also text accompanying note 50 (noting that Wilkes case indicated only that Parliament would no longer exclude elected persons for conduct judged to be improper after the fact but not covered by a prospective statutory disqualification); Powell, 
broad dicta) Powell did not mean the states lacked authority to add qualifications. Nonetheless, if the policy grounds driving the Powell decision are correct-that allowing Congress to add qualifications could lead to elitist exclusions and entrench current representatives-they also suggest the same conclusion for states. The dissent's reading of Powell thus left it with a federalstate distinction that was unpersuasive in terms of democratic policy because its basis lay not in such policy but in relatively legalistic and metaphysical claims about the meaning of state sovereignty in our federal system. ${ }^{67}$

Perhaps a better response would have been to challenge the premise that Powell applied to term limits. After all, Powell's sweeping statements that Congress lacked power to add any qualifications were dicta. The actual holding was only that the House could not exclude a particular member for his alleged misconduct. Such exclusions raise the concern of trumped-up charges being used to target political opponents and thus implicate Powell's concerns (and those of the framers) regarding the entrenchment of a current legislative majority. Powell could thus reasonably be read to prohibit Congress from adding only those qualifications that raise the legislative self-perpetuation concern. On this reading, term limits would be constitutional whether adopted by states or the federal government because, whatever their other evils, term limits cannot further legislative selfperpetuation. The better distinction was not between federal and state imposed qualifications, but between term limits and other qualifications.

B. Policy Grounds for Resolving the Legal Ambiguity

1. Democratic policy.

In the end, the Court conceded that the constitutional debates were "inconclusive." ${ }^{\text {" }}$ In resolving the ambiguity, it relied repeatedly on "the fundamental principle of our representative democracy ... that the people should choose whom they please to govern them." ${ }^{\prime \prime 9}$ Indeed, the Court itself identified this democratic

395 US at 527-31 (focusing on Wilkes case). But the dominant concerns of entrenchment would remain raised by a prospective statute, and much of the Powell opinion's logic applied equally to congressional statutes. See Powell, 395 US at 532-41, 547-48.

${ }^{67}$ See Part I.B.2.

US Term Limits, $115 \mathrm{~S} \mathrm{Ct}$ at 1848.

${ }^{9}$ Id at 1845, 1850-51, 1862 (internal quotation marks omitted). In addition to repeating this exact phrase no less than five times, the Court continually stressed different versions of this principle throughout its opinion. Id at 1848-51, 1857-58, 1860, 1862-64. See also id at 1866 (summing up that its conclusion is based on "the available historical 
principle as the "most importan[t]" factor in its decision, more important than "the text and structure of the Constitution" and "the relevant historical materials."

The policy argument was straightforward. Restrictions on whom voters could elect not only threatened legislative selfperpetuation and elitist exclusions but violated the core democratic value that voters are the best judges of who should represent them. This normally does seem a sufficient argument against imposing additional qualifications on candidates. If the voters do not like Communists, or Catholics, or renters, or persons refusing to pledge to support a flat tax, they can simply refuse to vote for them. They have no need to commit themselves to a legal bar on such persons running for office. But the Court failed to see that this reasoning did not apply to term limits. Voters could not simply vote for newcomers over senior incumbents because, as Parts II and III show, collective action problems penalized such a decision and entry barriers prevented viable opponents from entering the picture.

It appears that the Court did not even see these public choice issues, for it showed no hesitation whatever in brandishing its democratic principle to strike down what was, after all, a democratically adopted rule on narrowing the candidates. Had the Court seen the merits as at all debatable, the ambiguity of the constitutional legal materials would surely have made the Court hesitant to interfere with the democratic wishes of electorates favoring term limits. Its simplistic condemnation of term limits seems particularly striking given that the same Constitution provides term limits for the President, showing that even deliberative supermajorities can find term limits desirable.

If taken seriously, there are broader implications to the majority's claim that fundamental democratic principles required the invalidation of congressional term limits despite ambiguous constitutional legal materials. The claim suggests the Court should be amenable to the argument that even term limits on state representatives are unconstitutional, perhaps as a violation of the First or Fourteenth Amendments. And indeed several such challenges to state term limits have been raised in the wake of US Term Limits. ${ }^{71}$ No doubt the Court would recoil from that

and textual evidence, read in light of the basic principles of democracy"). To be sure, at the end of its opinion the Court gave lip service to not considering the merits of term limits, id at 1871, but this was belied by its repeated prior reliance on democratic policy and principle to justify its reading of the otherwise ambiguous textual and historical evidence.

${ }^{30} \mathrm{Id}$ at 1856.

${ }^{7}$ See, for example, Nevada Judges Assn v Lau, 112 Nev 51, 910 P2d 898 (1996); 
conclusion, not only because of precedent to the contrary, ${ }^{72}$ but also because it would bring into sharp relief a conflict-the Court would be saying states could not impose term limits on their executives even though the federal government does on its executive. However, the failure to extend its conclusion to the states brings into relief another incoherence: if it is fundamentally undemocratic to impose term limits on federal legislators, why not on state legislators as well? The Court gave no answer.

2. Federalism, metaphysics and default rules.

The dissent did not avoid similar policy incoherence, for it also adopted a federal/state distinction unrelated to democratic policy or principle: that additional qualifications for federal legislators could be imposed by states, but not by the federal government. But if the imposition of additional qualifications by Congress was undemocratic and unsound, why would it not also be undemocratic when imposed by states? The dissent barely addressed the issue, for its federal/state distinction was grounded not in policy but in a claim regarding the logical entailment of state sovereignty in our federal system. ${ }^{73}$ Nonetheless, two policy distinctions were implicit in its analysis, both based not on the substantive merits of the qualification at issue but on processbased claims about the identity of the body imposing the qualification.

First, the dissent argued that qualifications adopted by Congress instead of state legislatures posed a greater danger of elite or legislative self-perpetuation because federal legislators would be restricting their own opponents and thus had a greater conflict of interest. ${ }^{74}$ This does afford some grounds for distinction. But the grounds are not very strong. After all, elites or parties that control Congress tend to control state legislatures as well. If the Democrats during the New Deal had decided that all future candidates should be Democrats (or have some qualification that serves as a useful proxy for that), they probably could have imposed such a qualification as easily through the states as through Congress. ${ }^{75}$ Moreover, even if federally-imposed qualifications are

\footnotetext{
Bates $v$ Jones, 904 F Supp 1080 (N D Cal 1995).

${ }^{72}$ See Gregory v Ashcroft, 501 US 452, 462-63 (1991) (People of states have authority to set qualifications for state officials.).

${ }^{73}$ US Term Limits, $115 \mathrm{~S} \mathrm{Ct}$ at 1875-84 (Thomas dissenting).

"See id at 1890 .

${ }^{73}$ See Rafael Gely and Pablo T. Spiller, The Political Economy of Supreme Court Constitutional Decisions: The Case of Roosevelt's Court-Packing Plan, 12 Intl Rev L \& Econ 45, 60-64 (1992) (By 1936, the Democrats not only had two-thirds of both houses of Con-
} 
categorically more dangerous, that does not mean state-imposed qualifications are attractive or remotely democratic. A state legislature composed of millionaires might conclude that having a million dollars should be a qualification for federal office, or a state legislature composed of Republicans might find membership in their party a requisite qualification. The potential for abuse and self-perpetuation of a governing class or party remains.

Second, the dissent hinted that it was important to its conclusion that the qualification was imposed by voter initiative, not legislative statute. ${ }^{76}$ But the dissent never defended the proposition that the constitutionality of a state law could turn on whether it was adopted legislatively or by voters. ${ }^{77}$ Indeed the dissent supported the constitutionality of term limits even in states that imposed them legislatively. ${ }^{78}$ In any event, while voter adoption does lower the risk of elite or legislative selfperpetuation, it does not eliminate it, and democratic principles would remain compromised. Voters who are mostly homeowners or who belong to the current majority party might wish to preclude nonhomeowners or other parties from taking office in the future. Just because such qualifications might be imposed by majority vote does not make them democratic, for democracy means not a tyranny of the majority but a commitment to selfdetermination that leaves open the possibility that the majority of tomorrow might differ from the majority of today. ${ }^{79}$ To be sure, if the majority of voters wish to elect only homeowners or members of their party, they can already do so. But adding qualifications to that effect undemocratically imposes the views of the current electorate on future electorates. "Democracy envisions rule by successive temporary majorities." ${ }^{80}$ If one of those temporary majorities were permitted to entrench itself permanently, it would not only deny representation to a newly coalesced majority but also make representatives less accountable by undermining the mechanism by which voters can register their dissatisfaction. And it is difficult to see what prodemocratic virtue one could possibly see in such additional qualifications, no matter who adopted them.

\footnotetext{
gress but also controlled both houses in thirty-three of forty-eight states.).

${ }^{76}$ US Term Limits, $115 \mathrm{~S} \mathrm{Ct}$ at 1893-94, 1896, $1900 \mathrm{n} 22$ (Thomas dissenting).

$"$ No prior case had ever so held. See id at $1858 \mathrm{n} 19$ (majority opinion).

${ }^{78}$ Id at 1893 (Thomas dissenting).

${ }^{79}$ See Einer R. Elhauge, Does Interest Group Theory Justify More Intrusive Judicial Review?, 101 Yale L J 31, 103-04 (1991).

*o Tribe, American Constitutional Law \$ 13-18 at 1097 (cited in note 37).
} 
The dissent, however, never fully came to grips with these issues, for it focused on the meaning of state sovereignty in our federal system. To the dissent, the constitutional structure and language of the Tenth Amendment mean that our primary identity is as citizens of states that have partially ceded only defined portions of their sovereignty to the federal government and reserved the rest. ${ }^{81}$ Thus, wherever the Constitution does not expressly or implicitly address an issue, the proper "default rule" (i.e., the rule that operates by default absent contrary language) is that the states have power over it and the federal government does not. ${ }^{82}$ Since the Constitution is silent on term limits, by this logic states have the power to impose them though the federal government does not.

The Court was drawn into this discussion only to the extent of responding to the dissent's argument. It concluded that because the right to vote for federal representatives was a "new" right created by the Constitution, the states could "reserve" no power regarding it. ${ }^{83}$ Further, because federal legislators were not delegates from the states but representatives of the People of the United States, their qualifications were an inherently federal matter. ${ }^{84}$ Thus, on this issue, the proper default rule is that unless the Constitution delegates the matter to the states, they have no power over it. ${ }^{85}$ But fundamentally the Court did not see the question as one of state versus federal power. Rather, its emphasis was that neither the states nor the federal government had any power to add qualifications to those set by the Constitution. And the democratic principles it invoked applied equally to both levels of government.

Justice Kennedy was more enthralled by federalist metaphysics, but his concurrence reached a different conclusion than the dissent. To him, the "Framers split the atom of sovereignty. It was the genius of their idea that our citizens would have two political capacities, one state and one federal, each protected from incursion by the other." ${ }^{16}$ Unfortunately, such a theory offers no explanation of how to determine which side of the sovereignty atom we are on-all the policy questions are implicitly resolved by the largely unexplained location of the boundary line. Thus, Kennedy concluded state term limits were an "interference

\footnotetext{
${ }^{\star}$ US Term Limits, $115 \mathrm{~S} \mathrm{Ct}$ at 1875-84 (Thomas dissenting).

${ }^{\circ 2}$ Id at 1876.

$*$ Id at 1854-55 (majority opinion).

See id at 1863-64, 1871.

${ }^{*}$ See id at 1854.

Id at 1872 (Kennedy concurring).
} 
with the federal right to vote . . . in a congressional election," but one could have equally concluded that the Court's decision was a federal interference with the state right of voters to screen and select candidates for federal office. Kennedy's conclusion is completely determined by his premise that the issue is on the federal side of the atom, a premise that never receives a policy justification.

One could of course say the same of the dissent and of the majority's forays into federalist metaphysics. Each was grand and evocative, but each turned on definitional premises: whether the power was "new" or "reserved," whether our primary status is as federal or state citizens, whether the selection of representatives to Congress from a given state is a federal or state matter, and whether the "people" referred to in the Tenth Amendment are the people of the United States or of the individual states. And each offered little policy explication of why we should, given the inevitable ambiguities, adopt one definition over the other. Instead, we were treated to a conflict between largely conclusory intuitions and inferences that do nothing to advance the debate and indeed hinder it by obscuring policy premises.

The impulse to operate at a high level of abstraction is understandable. It allowed the majority to avoid explaining just how term limits could possibly further elite or legislative selfperpetuation. And it allowed the dissent to avoid explaining why the Qualifications Clauses should leave states free to adopt noxious qualifications categorically barred from federal adoption. But the impulse is hardly justifiable, nor required by the methodology of default rules. The default rule concept, coming from contract and corporate law, is a quite practical one. It holds that, where a contract or corporate charter offers no clear answer on a question, the matter should be resolved not by strained efforts to divine an intent of the contracting parties, but rather by reference to rules understood to apply by "default" unless the parties contract out of them. The application of this concept to constitutional and statutory interpretation is quite promising, albeit largely undeveloped, ${ }^{88}$ but it is plain that the source of default rules is not metaphysical but policy driven.

The contract and corporate literature provides two basic sources for default rules. The first, more dominant, source is the

Id at 1875.

“ It is the topic of a separate article on which I am currently working, tentatively entitled Statutory Default Rules. 
court's best guess about what rational parties in the position of the contracting parties would have contracted to had they thought about the subject. In contract and corporate law, this is generally presumed to be the rule that maximizes the aggregate wealth of the contracting parties, on the grounds that any effort to impose distributional shifts would be offset by price adjustments. In constitutional law, one might look more broadly to what rule would seem most desirable to parties without a vested interest in the matter at hand.

The second source is what are known as penalty defaults. Here the notion is that the default rule should be not the most desirable rule but rather a rule that penalizes one of the parties to encourage her to contract more explicitly about the matter. ${ }^{89}$ The theory is that explicit contracting will make the final set of contracts more efficient than they would be if relatively imprecise courts tried to guess about the most efficient rule for the parties. Penalty defaults are best limited to areas where explicit contracting seems likely to occur because, if the penalty default sticks, uncontracted out of, it worsens social welfare from where it would be if the most desirable default were used instead.

The dissent's default rule seems to be a penalty default. The opinion offered no argument that state power over the qualifications of federal officials reflected the most desirable rule. Rather, the dissent stressed the need for state consent to the Constitution the framers had drafted ${ }^{90}$ from which one might infer that the default rule of interpretation should be designed to force those framers to make any limitations on state power explicit. But the problem with this penalty default logic is the constitutional context. Given the difficulty of amendment, an undesirable default is likely to stick in perpetuity. Moreover, since almost all our constitutional contracting is behind us, the adoption of a penalty default has little prospective effect on future constitutional drafting. Finally, while we might have some hope of relatively complete contracting out of undesirable penalty defaults in the contractual and corporate setting, the range of issues in the constitutional setting is so vast that we cannot hope for anything close to complete contracting. Thus, ironically, default rule logic suggests courts should feel freer to import notions of general social desirability to resolve constitutional ambiguities than to resolve ambiguities in statutes, let alone those in contracts and

\footnotetext{
" See, for example, Ian Ayres and Robert Gertner, Filling Gaps in Incomplete Contracts: An Economic Theory of Default Rules, 99 Yale L J 87, 97-100, 128 (1989).

" See US Term Limits, $115 \mathrm{~S}$ Ct at 1875-77 (Thomas dissenting).
} 
corporate charters. Of course, often it will be clear that the most desirable rule for the contracting parties or society would be that courts not make ongoing case-by-case judgments of desirability. I turn to this problem next.

3. The slippery slope and institutional competence.

In line with the efficient default school, one might conclude that, given the ambiguous legal materials, courts should conclude that the Qualifications Clauses bar only those qualifications that raise the risk of undemocratic exclusions and self-perpetuation. True, the Court would lack authority to impose such a rule absent some constitutional basis. But the ambiguous materials provide enough basis for judicial authority, especially given that, amidst the ambiguity, one thing was clear: the framers were concerned that undemocratic qualifications might be adopted to perpetuate a governing elite or legislature. ${ }^{91}$

This conclusion must, however, confront an argument the Court did not make-the slippery slope argument. Suppose a court accepted both the interpretation that only undemocratic qualifications are unconstitutional and the conclusion of this Article that term limits are not undemocratic. Nonetheless, it might reasonably be concerned that if it starts down the slope, it will face other qualifications whose classification as pro- or antidemocratic would be more slippery. Would it be prodemocratic to exclude candidates of fascist or communist parties from running for election, at least if those parties made clear their intent to overthrow democracy if in office? Undemocratic to exclude candidates without property or with too much of it? To exclude those with legal training or without families? Or those who had not taken college-level civics?

Even seemingly easy cases might be more difficult on closer examination. An exclusion of felons might, for example, seem to present an easy case of constitutionality. But the old John Wilkes case itself showed that felony charges can be politically motivated, ${ }^{92}$ and the current practice of seeking investigations and prosecutions of political opponents hardly provides convincing evidence that the days of such concerns lie behind us. From the opposite extreme, a blatant exclusion of, say, Republicans seems clearly unconstitutional. But one might reasonably fear that legislatures will pose hard cases by adopting formally benign qualifications that nonetheless serve as effective proxies for member-

"2. Id at 1849-51, 1856-57, 1862-63 (majority opinion). See also Part I.A.3.

${ }^{92}$ See Part I.A.4(a). 
ship in the opposing party. Once the camel's nose is in the tent, keeping out the rest of the camel can be impossible.

The slippery slope argument really encompasses two subarguments. First is the "pure" slippery slope argument, that the principle against undemocratic qualifications is so slippery that no one could maintain a sharp distinction between the instant case (term limits) and the bottom of the slope (more noxious qualifications). ${ }^{93}$ Second is the argument against giving added authority to a particular entity. Here, the argument is that courts should not have a power to decide which qualifications are democratic because they either are likely to misuse it or lack the institutional competence to exercise it. ${ }^{94}$ Even in the case of term limits, for example, one may doubt the capacity of courts to reach any definitive resolution of the complex issues identified in Parts II and III.

If the slope were too slippery to undertake, the Court had only two options: it could condemn all additional qualifications or allow all of them. The former meant the invalidation of seemingly benign laws, such as those disqualifying candidates who were prisoners, mental incompetents, or convicted of vote fraud..$^{95}$ But presumably there was little risk of voters voting for such folk anyway. Given the self-policing by voters of unqualified candidates, the extreme of prohibiting all additional qualifications seems preferable to the extreme of allowing all of them, especially when one considers the framers' clear concerns about legislative self-perpetuation. ${ }^{96}$

Such arguments might strike me as persuasive but for the fact that the Court has long been engaged in reviewing the le-

\footnotetext{
See Frederick Schauer, Slippery Slopes, 99 Harv L Rev 361, 370-71 (1985). Schauer's delightful piece argues in part that such slippery slope arguments depend on claims about linguistic imprecision or limited comprehensibility, suggesting that such arguments often lack plausibility because more precise language is possible. Id at 370-76. But the slope's slipperiness may be determined by the principles that would be deemed acceptable interpretations of the legal materials. For example, one surely could linguistically give the slope excellent traction by interpreting the Qualifications Clauses to embody the following principle: term limits are constitutional but all other additional qualifications are unconstitutional. However, the legal materials provide no basis for drawing that line. Courts are restricted to the principles that might plausibly be generalized from the legal materials, and if those are all either extreme (all additional qualifications valid or invalid) or slippery (invalidating only "bad" or "undemocratic" qualifications), then courts have a slippery slope problem no matter how linguistically possible a high-traction solution might be.

4 See id at 367-68.

$\therefore$ US Term Limits, $115 \mathrm{~S}$ Ct at 1909 (Thomas dissenting).

* See Part I.A.3. While such concerns were focused on federally-imposed qualifications, there is little policy ground to distinguish federally- and state-imposed qualifications. See Part I.B.2.
} 
gitimacy of the qualifications states impose on candidates for state office and on voters for both federal and state office. The Court normally does so under the First and Fourteenth Amendments, since the Qualifications Clauses do not apply. ${ }^{97}$ The result has apparently not been a pell-mell slide down an unmanageable slope. Indeed, given that the state power to set qualifications for federal voters ${ }^{98}$ is not only no less slippery to review but offers far more potential for abuse than a power to qualify federal candidates, an absolute prohibition on the latter offers little additional protection. In any event, the doctrine already built up under the First and Fourteenth Amendment creates guide rails for courts to keep their footing in the future..$^{99}$ When subjected to such review, term limits on state officials have survived without difficulty. ${ }^{100}$

Moreover, the Court's opinion was susceptible to its own slippery slope problem, for it invalidated not just absolute bans on incumbents running but bans on their getting ballot access on the grounds that laws with the purpose and effect of handicapping a class of candidates violated the Qualifications Clauses. ${ }^{101}$ Clearly the ballot restriction had such a purpose and effect. But, as the dissent pointed out, if one is willing to invalidate any law with such a purpose or effect, then a host of laws might be unconstitutional: campaign finance laws on the theory that they handicap challengers to help incumbents (or vice versa); or the drawing of district lines (including both normal gerrymandering to help a party and majority-minority districts to help a race) because it makes it harder for some candidates to win election. ${ }^{102}$

\footnotetext{
${ }^{97}$ See US Term Limits, $115 \mathrm{~S}$ Ct at 1913 (Thomas dissenting) (noting that those clauses have been used to review laws that handicap particular classes of candidates). The availability of such First and Fourteenth Amendment review might be thought to save the dissent's position, for it would also serve as a backstop policing noxious qualifications even if the Qualifications Clauses were inapplicable. Compare Part I.B.2. With regard to states, then, the dissent's position may effectively boil down to the same as that advocated here, with the only difference being that the dissent would locate the authority for constitutional review in a different clause. But the dissent would retain a distinction between state and federally added qualifications, for only the latter would be categorically banned, and that distinction cannot be justified by any strong policy distinction. US Term Limits, 115 S Ct at 1913 (Thomas dissenting).

ss See US Const, Art I, $\$ 2$, cl 1 (giving states power to qualify federal electors).

${ }^{99}$ See generally Tribe, American Constitutional Law $\S \S 13-10$ to 13-21 at 1084-1112 (cited in note 37 ).

${ }^{100}$ US Term Limits, 115 S Ct at 1913 (Thomas dissenting) (collecting cases). See also Tribe, American Constitutional Law $\$ 13-19$ at 1098 (cited in note 37) (noting that candidate eligibility requirements generally receive rational basis scrutiny).

${ }^{101}$ US Term Limits, $115 \mathrm{~S}$ Ct at 1868.

${ }^{102}$ Id at 1913-14 (Thomas dissenting).
} 


\section{The possibility of constitutional amendment.}

Still, one might find the issue of qualifications for federal legislators distinguishable, perhaps not because it is more slippery but because its greater importance makes similar slipperiness intolerable. If so, only a constitutional amendment could draw an acceptably nonslippery line between term limits and other additional qualifications. As a practical matter, that is where US Term Limits leaves us. ${ }^{103}$

But even if federal term limits are immensely desirable, this makes their adoption rather hopeless, does it not? The Constitution provides for amendment, but only if proposed by two-thirds of both houses of Congress or by a convention applied for by twothirds of the state legislatures. ${ }^{104}$ It must also be ratified by three-fourths of the state legislatures. ${ }^{105}$ And if anything is clear about term limits, it is that incumbent legislators are loath to enact them. Only two of the twenty-four state term limits were passed by state legislatures; the rest were all by popular initiative. ${ }^{106}$ Congressional Democrats have consistently opposed term limits when they were in the majority. Having trumpeted term limits while in the opposition, Republicans have felt obliged to continue to voice support for them after their 1994 takeover of Congress. But they have done so with all the enthusiasm of a boy asked to dance with his sister, being careful to fall short of the two-thirds vote needed to actually propose an amendment. ${ }^{107}$ If incumbent legislators have a veto on term limits, the likelihood

${ }^{103}$ Term limits proponents might also attempt constitutional change via judicial appointment-that is, appointing a new justice committed to overturning the 5-4 decision in US Term Limits. But this would not avoid slippery slope problems, and it would cause a wrenching conflict with stare decisis principles that are generally well worth sustaining. There are also serious practical problems with such a strategy. Litmus tests are hard to implement and enforce, and it is perilous to predict how new justices will vote. Furthermore, among the justices in the US Term Limits majority, only Justice Stevens is old enough to make his retirement and replacement a realistic strategy over the next ten years. Even if he were successfully replaced by a new justice who would vote differently on term limits, stare decisis might well drive one of the original four dissenters to switch sides if the same issue were raised again. In any event, the more fundamental problem remains that, like constitutional amendment, the judicial appointment strategy still gives the legislature an effective veto since the Senate must confirm any nominee.

in US Const, Art V.

${ }^{105}$ Ratification may also be by state convention, id, but Congress has exclusive power to decide what ratification procedure to use. See Tribe, American Constitutional Law \$36 at 64-65 $\mathrm{n} 9$ (cited in note 37). It can thus require ratification by state legislatures if that is more likely to block term limits. To date, only one of the twenty-seven amendments has been ratified by state conventions. Id.

${ }^{16}$ Sullivan, 109 Harv L Rev at $78 \mathrm{n} 1$ (cited in note 5). See also note 6.

${ }^{107}$ See Benjamin Sheffner, Term Limits Plan: Constitutional Convention, Roll Call 6 (Dec 18, 1995) (227 votes in House, 63 shy of 290 needed for two-thirds; 45 votes in Senate, 22 shy of 67 needed). 
of getting them adopted seems as high as getting university professors to voluntarily give up tenure.

Granted state legislators have no direct incentive to oppose term limits for federal officials. But any incumbent legislator can be expected to be relatively biased against arguments that incumbency is bad. ${ }^{108}$ Moreover, state legislatures can circumvent the need for congressional approval only by applying for a convention that might not produce the desired amendment and might produce other amendments that are not desired. This uncertainty has proven a big enough disincentive that no constitutional amendment has ever been produced by constitutional convention. ${ }^{109}$ Finally, if the party in control of Congress controls at least one state legislative chamber in one-fourth of the states, which it always has, it can block ratification. The practical effect is to give any congressional majority an effective veto against constitutional change contrary to its interests. Indeed, even when two-thirds of the states apply for a constitutional convention, Congress must vote to call for it. ${ }^{110}$

All this seems particularly perverse in this context since Madison explained that the root cause of his entrenchment concern about giving legislatures the unfettered right to add qualifications was that "the representatives [ ] have a personal interest distinct from that of their Constituents." "111 Yet the Court's decision effectively gives that same legislature a veto over a qualifications change designed to reduce entrenchment that those same legislatures have a personal interest in opposing. Should the will of the people be thwarted in this fashion?

Perhaps not, if a novel theory by Yale Law Professor Akhil Amar is recognized. Amar argues that Article V sets the exclu-

\footnotetext{
${ }^{108}$ One might think that state legislators would like to impose term limits on federal legislators so the state legislators could move up to the federal position, but state legislators are probably more worried about term-limited federal officials coming after the state legislators' jobs. And if they do hope to move up to the federal level, they are likely to disfavor laws that limit the amount of time they can serve once they get there.

${ }^{109}$ Tribe, American Constitutional Law \$ 3-6 at 64-65 n 9 (cited in note 37).

${ }^{110}$ US Const, Art V. This might be read to give Congress not just an effective but an absolute veto on constitutional change. However, the better reading (given the historical evidence) is that Congress has an essentially ministerial obligation to call for a convention upon application by two-thirds of the states. See American Bar Association, Special Constitutional Convention Study Committee, Amendment of the Constitution by the Convention Method Under Article V 12-18 (ABA 1974). Still, even a ministerial role involves significant power to determine whether two-thirds of the states have made the requisite application in a sufficiently contemporaneous manner and power to delay and influence the shape and composition of a convention. See id at 17-20; Patrick J. Fett and Daniel E. Ponder, Congressional Term Limits, State Legislative Term Limits and Congressional Turnover: A Theory of Change, 26 Political Sci \& Politics 211, 213-14 (1993).

"Farrand, 2 Records at 250 (cited in note 24).
} 
sive means by which government officials can amend the Constitution, but does not bar the People from amending the Constitution directly through a simple majority vote. ${ }^{112}$ The historical and textual arguments are fascinating, but would take us too far afield. ${ }^{113}$ However, the basic policy argument for the distinction will readily be grasped by students of public choice theory. The Constitution is essentially a contract limiting the authority of the People's agents, who make up the government, and one does not let agents rewrite their own agency contracts freely. The grounds for oversight and onerous procedure are less powerful when the principal, the People themselves, has amended the agent's authority.

This theory has considerable problems, not the least of which is determining exactly when a majority of the People have officially amended the Constitution. Moreover, how could we ever get 250 million people to decide anything meaningfully without going through procedures (like conventions or elections) run or set up by agents just as suspect as the government agents subjected to the onerous Article V procedure? There is also the problem of how a Constitution can protect against majoritarian tyranny when the majority is free to alter the Constitution at will, a matter that should concern all the People since everyone is in the minority on some issue and might become part of a broader political minority in the future. These problemsuncertainty, instability, irreducible agency costs, and majoritarian exploitation-suggest the People would rationally decline the independent amendment power Amar would give them, ${ }^{114}$ at least absent a situation where government officials would be biased against the amendment.

But for present purposes it suffices to note that, if it applies anywhere, Amar's theory should apply to term limits. For, unlike with most amendments, there are clear reasons why legislators might have biases leading them to block the preferences of the voters for term limits. And with term limits there has been a procedure by which the will of the People has been registeredstate-by-state ballot initiatives. If each state holds such a vote, and a majority of those voting approve congressional term limits,

${ }^{112}$ See Akhil Reed Amar, The Consent of the Governed: Constitutional Amendment Outside Article V, 94 Colum L Rev 457, 458-59 (1994).

${ }^{113}$ For a biting critique of Amar's textual and historical arguments, see Henry Paul Monaghan, We the People[s], Original Understanding, and Constitutional Amendment, 96 Colum L Rev 121, 126-73 (1996).

"'See Charles Fried, The Supreme Court, 1994 Term: Foreword: Revolutions?, 109 Harv L Rev 13, 31-32 (1995) (The People have consented to a regime of more regularity in the expression of their own will.). 
we would have as good a test case of the Amar theory of constitutional amendment as one could imagine. The irony is that the Amar theory rests on a premise - the preeminence of the People's status as federal rather than state citizens-directly contrary to the premise of Thomas's dissent.

\section{THREe COLLECTIVE ACtION PROBLEMS}

A. The Basic Model

1. Lessening ideological slack.

It is perhaps best to begin with a concrete example. Suppose every district has similarly senior representatives and receives and pays for a similar share of governmental benefits. One district is represented by Sally Conservative. Sally's views on ideological issues have become increasingly more conservative than those of the voters in her district. Those voters would prefer someone with more liberal views. However, if they replace Sally with a newcomer whose ideological views more closely match the district's electorate, the district will lose seniority. With less seniority, the district will get a smaller share of distributable governmental benefits, though it will still bear an equal share of the costs. The district's voters vote to retain Sally because they value her greater ability to deliver governmental benefits more than her divergence on ideological issues. Other districts retain incumbents who are more liberal than their electorate for the same reason.

Why should this be a problem? After all, no candidate can ever perfectly reflect everyone's views. In choosing candidates we must choose between bundles of positions and abilities and trade off favorable views and abilities on some issues with unfavorable views and abilities on other issues. That voters reelect Sally must mean they prefer the advantage of her ability to deliver governmental benefits to any disadvantage from divergence on ideological issues. They cannot overall prefer a newcomer to Sally, or else they would not vote for Sally.

However, this is true only because of a collective action problem. ${ }^{115}$ If all the districts could do so collectively, they would

\footnotetext{
${ }^{115}$ Although I originally developed this analysis independently in 1990, and published a brief outline of the argument in Einer Elhauge, Term Limits: Voters Aren't Schizophrenic, Wall St J A14 (Mar 14, 1995), the honor of being the first publication to point out the connection between term limits and a collective action problem goes to Dick and Lott, $50 \mathrm{~J}$ Pub Econ at 8-9 (cited in note 7). See also Calamita, Comment, $8 \mathrm{~J} \mathrm{~L} \mathrm{\&} \mathrm{Pol} \mathrm{at} \mathrm{579-81}$ (cited in note 9) (noting the penalty on ousting powerful incumbents without linking it to the collective action problem); Hills, 53 U Pitt L Rev at 144-45 (cited in note 61) (same);
} 
prefer to replace their senior legislators with newcomers having closer ideological views. for, if every district does so, no district loses any advantage in getting a share of governmental benefits and each district gains more accurate representation on ideological issues. But, acting individually, each district will retain its senior legislator no matter what it assumes the other districts will do. If it assumes the other districts will retain their legisla-

Eugene Mills, Term Limits and the Prisoner's Dilemma, 10 Pub Affairs Q 143 (1996) (subsequently pointing out the same collective action problem); James M. Buchanan and Roger $\mathrm{D}$. Congleton, The incumbency dilemma and rent extraction by legislators, $79 \mathrm{Pub}$ Choice 47, 48-49 (1994) (describing a similar collective action explanation). See generally Mancur Olson, Jr., The Logic of Collective Action: Public Goods and the Theory of Groups (Schocken rev ed 1971) (explaining the collective action problem more generally). Mills argues that Dick and Lott did not identify the same problem because they called it a free rider problem, which can differ from the collective action/prisoner's dilemma problem. See Mills, 10 Pub Affairs $Q$ at 151-52 n 15. But this is an uncharitable reading since Dick and Lott do note the defining feature of such a problem: that all parties can be made better off by collectively agreeing to refrain from activity that is individually attractive. See Dick and Lott, $50 \mathrm{~J}$ Pub Econ at 1, 4, 8. See generally Russell Hardin, Collective Action 25-28 (Johns Hopkins 1982) (showing that collective action and prisoner's dilemma problems are essentially the same). Mills also distinguishes Dick and Lott's account as too "technical" to describe realistically the motives of actual voters, Mills, 10 Pub Affairs Q at $151 \mathrm{n} \mathrm{15}$, but this distinction too is unpersuasive. While Dick and Lott's particular model is probably too mathematical for the average voter, the underlying free rider, collective action, and prisoner's dilemma concepts are equally easy (or hard) to understand and equally amendable to plain English or mathematics. In any event, it is unlikely actual voters had any such academic concepts in mind, but this hardly means they did not have intuitive notions amounting to the same or that it matters to the inquiry what their subjective state of mind was. See note 13. Dick and Lott must be given the credit they are due.

Dick and Lott's work is, however, more limited than this Article in various ways. First, it assumes that all political participants are rational egoists whose sole motive is to maximize governmental transfer payments. Dick and Lott, $50 \mathrm{~J}$ Pub Econ at 5-6. See also Buchanan and Congleton, 79 Pub Choice at $47-48$ (assuming legislative process is a distributive game). This Article generalizes the problem to include more realistic assumptions that participants have and express ideological preferences and behavior. Second, this Article shows how collective action problems can produce senior representatives who do not accurately reflect voter preferences not only in the allocation of transfer payments but on any political issue. See Part II.A.1. Third, prior work (including mine) has assumed that collective action problems resulted solely because clout over distributable benefits varied with legislator seniority. This Article shows that collective action problems can result even if seniority affects clout over ideological issues only. See id. Fourth, this Article goes beyond the divergence between district preferences and representative behavior to describe how term limits can also alleviate two other separate collective action problems: (1) reducing overall pork levels, see Part II.A.2; and (2) facilitating the mutual ouster of senior representatives liked by their own districts but considered noxious by other districts, see Part II.A.3. Fifth, this Article explains the connection between the nature of the collective action problem and variations in support for term limits among different political parties, districts, eras, and jurisdictions. See Parts II.B.3 and II.C. Sixth, this Article explains why states would ever pass term limits on their congressional delegations given similar collective action problems, see Part II.D. Compare Part II.D with Mills, 10 Pub Affairs $Q$ at 152 n 17 (finding this inexplicable) and Tabarrok, 14 Cato $J$ at 344 (cited in note 12) (likewise finding it inexplicable under collective action theory). 
tors, it will retain its legislator because ousting her would penalize the district with a lower share of governmental benefits. If it thinks the other districts will oust their legislators, it will still retain its legislator because she will be able to deliver an even bigger share of governmental benefits and they still value those benefits more than accurate representation on ideological issues. Since each individual district makes the same calculation, none ousts its senior legislator.

As a result, all districts can be made better off by collectively agreeing to oust their senior legislators with term limits. So far, I have said nothing about the overall level of governmental action producing benefits for particular districts. Seniority need only be assumed to enable districts to get a greater share of any governmental benefits there are to distribute. Nor have I made any assumption about whether those governmental benefits are desirable or not. ${ }^{116}$ The first benefit of term limits is reduced ideological slack, whether or not the current level of governmental benefits is desirable or affected by term limits.

As I use it, the term "ideological" includes any view on governmental action that does not depend on the distribution of that action across districts. For example, abortion is an ideological issue because one's views about abortion are unlikely to be affected by the distribution across districts of its benefits and costs. But, given my definition, "ideological" extends far more broadly than the term is ordinarily used. If a certain district's position on tariffs is driven solely by views on free trade that apply equally whether or not the tariff differentially impacts local producers, then the issue is "ideological" in that district. A district might also have ideological views on whether a program is enacted but nonideological views on how any benefits of that program are distributed across districts. The term "ideological" also includes matters that might ordinarily be called questions of character,

\footnotetext{
${ }^{116}$ In an earlier piece, I asserted that ideological slack resulted from the link between seniority and the distribution of undesirable pork. See Elhauge, Term Limits, Wall St J at A14 (cited in note 115); see also Mills, 10 Pub Affairs Q at 145-46 (cited in note 115) (similar assumption that seniority clout over pork created the collective action problem in question). Upon reflection, this limitation to pork was mistaken. As long as some governmental action confers net benefits on some districts and more senior legislators have greater power to affect the distribution of those net benefits across districts, then the collective action problem will result even if all governmental action desirably has national benefits that exceed national costs. (Shortly before publication, I came upon an article making effectively this same point within a different model. See Buchanan and Congleton, 79 Pub Choice at 47-48 (cited in note 115).) In addition, for reasons noted below, the link between seniority and legislative clout can create collective action problems even if all issues are ideological. See Part II.A.3.
} 
such as whether the legislator is involved in a sex scandal or bounced checks at his congressional bank.

Now we need to add another point. Increased seniority gives a legislator more clout not only over distributing governmental benefits but also over many ideological issues. As long as the legislator's ideological positions coincide more with the district's than they diverge, the increased clout on ideological issues that comes with seniority confers a net ideological benefit on the district. ${ }^{117}$ Thus, a legislator with some ideological slack may still do a better overall job of fulfilling the ideological preferences of her constituents if she has more power to get ideologically compatible legislation through. But if the legislator becomes more ideologically divergent than compatible, the effect of her seniority on ideological issues becomes affirmatively unattractive.

Within that limit, however, the effect of seniority on ideological issues creates a collective action problem. Indeed, it is a problem that would exist even without any distributable governmental benefits. Each district has incentives to vote for a senior incumbent over a newcomer with less ideological divergence because the incumbent has more clout on the ideological issues where his positions coincide with the district's. But because total legislative power is a fixed sum, the districts cannot collectively increase their power by having senior legislators. They can only try to increase their relative power. And since each other district does the same, not even relative power is increased. They would all thus be better off with less senior legislators, who collectively would have no less legislative power but who would better reflect the ideological views of each district.

Nothing in the foregoing analysis relies on the traditional law and economics assumption that voters and other political participants are rational egoists, concerned only with their material well-being and maximizing governmental transfer payments. ${ }^{118} \mathrm{I}$ merely assume that whatever aims the participants pursue, they do so rationally. Indeed, one major purpose of this Article is to demonstrate that term limits can be attractive even to those who think the political process more frequently involves the pursuit of ideological aims that do not confer material benefits on those pursuing them. The essential collective action problem is that-no matter what legislative power is used for-each district has incentives to try to increase its relative legislative

\footnotetext{
"1"See Appendix.

"1" Past law-and-economics models of the collective action problem addressed by term limits have relied on such assumptions and thus been more limited in their appeal and ability to explain behavior. See note 115 .
} 
power by reelecting incumbents, but collectively no overall increase is possible since the total amount of legislative power is fixed.

2. Lessening pork levels.

Now let us divide distributable governmental benefits into two categories: "pork" and "nonpork." Often pork is defined in a narrow way that puts it at $\$ 10$ billion-an annoyance, but at 0.5 percent of federal spending, perhaps too small to justify dramatic changes in electoral procedure. ${ }^{119}$ But my definition of "pork" is far more capacious. It includes any governmental action whose total costs across all districts exceed its benefits but which some subset of districts nonetheless favors because the benefits are more concentrated in those districts than the costs. The classic case might be an unnecessary dam put in a district to create jobs there and funded by taxes collected from all districts. But pork can include regulations or tariffs that discriminate against sugar importers and are favored by certain districts because they benefit local sugar producers and spread their costs across a nation of sugar consumers. And it can even include entitlements like Social Security if some districts have more elderly than others and thus disproportionately benefit. Any other distributable governmental benefit, whether desirable or not, is "nonpork."

Lest one think I am imposing an efficiency norm on a political system that may justifiably be seeking other ends, I hasten to add that benefits and costs need not be measured monetarily. A utilitarian might prefer to measure them in utiles, an egalitarian in terms of whether they move us closer or further from an equal distribution of wealth, another in terms of moral pluses and minuses. The problem that remains under any normative baseline that admits the need for some tradeoffs ${ }^{120}$ is that the pluses might outweigh the minuses in some districts but not in all the districts as a whole. And this might cause individual districts to vote quite differently than they would if they considered the effect on all districts. This is the problem of pork broadly understood. Under any normative baseline, some governmental action would be classified as undesirable pork. ${ }^{121}$ The following model

\footnotetext{
${ }^{119}$ See Daniel Shaviro, The Political Economy of Budget Deficits 376 (1994 draft on file with U Chi L Rev).

${ }^{120}$ Since legislation occupies the realm left to political judgment rather than the realm of absolute rights enforceable against the government, legislative issues presumably involve such tradeoffs.

${ }^{121} \mathrm{I}$ initially assume that all districts share the same normative baseline for determining what counts as pork. I relax that assumption in Part II.C.1.
} 
can thus be brought to bear even by those who wholly reject economic efficiency as a social goal. ${ }^{122}$

Suppose seniority affects not only the distribution of pork but also its overall level. That is, a legislature composed of longserving legislators will tend to create and pass more pork than a legislature composed of newcomers. Then there is a second collective action reason why districts will tend to vote for senior representatives but favor term limits. Voters favor pork in their districts only because they enjoy all the benefits and spread the costs over all districts. But they suffer from the costs of funding pork for all the other districts. Since, by definition, pork costs more than it is worth, each district would enjoy a net gain if pork in all districts were lowered equally.

If each district wants less pork, why don't they just vote for legislators who generate less of it? Because the benefits of reduced pork levels must be shared with all the other districts whether or not the other districts contribute by pushing for less pork. In contrast, each district that elected a low-pork legislator would bear all the costs of virtuously refraining from taking its share of the total pork distributed. Thus, each individual district rationally declines to penalize an incumbent who votes for pork even if the district would prefer lower pork levels and the collective ouster of all representatives who vote for pork. ${ }^{123}$ Ergo, the districts vote for term limits as a means of overcoming this collective action problem and achieving the lower overall amount of pork each district prefers.

3. Getting rid of other districts' representatives.

In lessening pork levels, each district effectively trades its senior representative to eliminate senior representatives from other districts. This benefits each district because the costs of the pork avoided in other districts exceed the benefits of the pork

\footnotetext{
${ }^{12}$ Again, past models have been more limited, assuming economic efficiency as the measure of social desert. See note 115.

${ }^{1}$ The fact that a legislator suffers no penalty for approving pork distinguishes this problem from ideological slack. As long as other districts are approving and splitting pork, each district rationally wants a representative who engages in pork barrel politics. See Part II.B.3. A representative who approves pork is thus not ideologically diverging from his electorate. Of course, if the representative's votes on pork levels did diverge from the district's wishes, there would still be the problem that removing him would penalize the district with a lower share of pork and other distributable governmental benefits. But that is the same problem with any ideological divergence, and a representative who diverged from his district's wishes on pork levels would be able to diverge less on some other issues.
} 
forgone in their districts. Could similar trading occur over ideological issues? Yes.

Imagine a North Carolina voter who on ideological issues loves Jesse Helms but who hates Ted Kennedy even more. Or a Massachusetts voter who hates Helms more than she loves Kennedy. Each voter would benefit on purely ideological grounds by giving up her favored senior representative in exchange for the other voter giving up hers. National term limits would effectively allow them to consummate such a trade. Moreover, such a situation creates a rationale for term limits even if representatives do not ideologically diverge from their own districts and even if term limits would not reduce overall pork levels.

To be clear, I am not claiming any systematic reason why a district's electorate would be more offended by the contrary ideological views of other districts' representatives than it is pleased by the conforming ideological views of its own representative. I claim only that it is plausible this might sometimes be the case, at least for some significant share of voters favoring term limits.

Where it is the case, the voters again face a collective action problem in ordinary elections. Although each district might be willing to oust its ideologically favored representative in exchange for being rid of the ideologically noxious representatives from other districts, no district has incentives to do so in ordinary elections. For any such unilateral ouster would do nothing to assure that other districts follow suit.

But why should such voters have any confidence that the junior legislators who replace the departing senior ones will be any less ideologically noxious? After all, the views of the junior legislators may be no more noxious if, as posited for purposes of this subsection, the district favors the ideological views of the departing legislator. ${ }^{124}$ But the departing senior legislator would have had more clout to further those ideological views, and would thus have a greater adverse effect on those in other districts with contrary ideological views. If the districts suffer a net ideological loss from each district having its favored ideological representative, the magnitude of that loss can be reduced if the seniority of those representatives is likewise reduced.

${ }^{124}$ Given the greater brandname advantages described in Part IV, the departing senior legislator may also have been able to sustain a more extreme ideology than the entering junior legislator could. But I defer discussion of such brandname advantages until that Part. 
4. Conclusion.

As the above analysis suggests, there is not just one collective action problem at issue but three distinct ones. Any of them, either singly or in combination, provides ample explanation why voters could justifiably favor term limits even though they vote for incumbents. What is individually desirable (keeping one's own incumbent) need not be collectively desirable (keeping all incumbents).

None of the above theories implies the districts must dislike their own incumbents. They like them, which is why they continue to reelect them. Whatever defects the incumbents have are offset (given their seniority advantage) by their greater ability to provide the pork, the distributable benefits, and/or the ideological gains each district sincerely values. ${ }^{125}$ What Americans do not like is the seniority advantage itself and the collective representation they receive in Congress. Typical polls at the time term limits were first being enacted showed that while more than 85 percent of Americans expressing a view approved of their individual congressman, ${ }^{126} 78$ percent of them disapproved of Congress. ${ }^{127}$ This apparent gulf can readily be explained by the various collective action problems described above. And the connection to term limits is that such limits would help districts produce a Congress and a set of incumbents that they would like far more. Thus term limits would improve, not worsen, the accuracy with which the legislature reflects the democratic preferences of the electorate.

\section{B. Justifying the Model's Assumptions}

1. The effects of seniority.

I assume greater seniority helps legislators deliver a larger share of governmental benefits to a district. I also assume (separately) that seniority gives a legislator more clout on ideological issues. This is easy to see under our current system, for it gives senior legislators more powerful committee assignments, bigger staffs, and a greater chance at leadership positions. One might object, however, that this effect of seniority is an artifact of

\footnotetext{
${ }^{12}$ Even if an incumbent displays ideological slack from the district, the incumbent would, under this model, be the best the district could do under the current system and thus be popular. That would not, however, mean the district could not do even better by changing the system.

${ }^{1 *}$ See Warren E. Miller and Santa Traugott, American National Election Studies Data Sourcebook, 1952-1986 341, 371 (Harvard 1989).

${ }^{127}$ Calamita, Comment, $8 \mathrm{~J} \mathrm{~L} \& \mathrm{Pol}$ at 560 (cited in note 9).
} 
that current system. If so, the collective action problem I describe could be cured more directly by abolishing that seniority system. Rather than adopt term limits, perhaps Congress should just cease allocating committee assignments and staffs by seniority. There is something to this, and it is not surprising that a Republican House relatively more sympathetic to term limits has also been less wedded to allocating committee assignments by seniority. But it cannot serve as a substitute for term limits.

First, no matter what the internal system in the legislature, more experienced legislators will have greater ability to work the system. ${ }^{128}$ Experience in office increases a legislator's familiarity with legislative rules and procedures and the process by which governmental benefits are distributed, pork is passed, and statutes with ideological impact are enacted or blocked. Senior incumbents will also have developed the contacts, reputations for honoring deals, and political favors necessary for logrolling. They will also be more skilled at recognizing problems of legislative cycling and path-dependence and at manipulating the agenda to take advantage of them.

This last point may require some explanation. A legislative majority can cycle between policy options even though each individual legislator rationally ranks them in an intransitive noncycling fashion. ${ }^{129}$ For example, suppose one-third of the legislators preferred $A$ to $B$ to $C$, one-third preferred $B$ to $C$ to $A$, and onethird preferred $C$ to $A$ to $B$. Then, by a vote of $2-1, A$ would beat $B, C$ would beat $A$, and $B$ would beat $C$. Unless a previously defeated option cannot be raised again, this produces an infinite cycle. To avoid such cycles, legislative procedure generally does not allow the previously defeated option to be raised again. But then the outcome depends solely on the order in which the options are voted on. ${ }^{130}$ More senior legislators are more likely to have the necessary knowledge about other legislators' priorities to spot such situations and determine which order of voting is most likely to produce their preferred result. They are also likely to be better at manipulating the agenda that determines that order, as

\footnotetext{
${ }^{122}$ See John R. Hibbing, Congressional Careers: Contours of Life in the U.S. House of Representatives 163 (North Carolina 1991) (finding that holding formal positions has little impact on measures of legislative effectiveness once one controls for tenure, suggesting that tenure, not position, is the cause of effectiveness); John R. Hibbing, Contours of the Modern Congressional Career, $85 \mathrm{Am}$ Pol Sci Rev 405, 424 (1991) (same).

${ }^{12}$ See Elhauge, 101 Yale L J at 101-02 (cited in note 79) (summarizing and collecting sources).

${ }^{130}$ If the first vote is between $A$ and $B$, then $C$ wins. If between $A$ and $C$, then $B$ wins. If between $B$ and $C$, then $A$ wins. As this simple example suggests, it is generally advantageous to go last in the agenda.
} 
well as to have positions that give them direct agenda-setting power.

Second, it would be undesirable to wholly eliminate a legislative seniority system because it has virtues unrelated to the distribution of governmental benefits and ideological clout. Presumably we do not want a newcomer heading a foreign relations committee her first day on the job. Expertise and experience about both subject matter and legislative procedure are helpful, which is why many term limits proponents oppose more extreme forms that would limit legislators to six years in office rather than twelve. ${ }^{131}$ (Note, however, that nothing in term limits means the new candidates will lack substantive expertise. The freshman Senator may have served twelve years on a House foreign relations committee; the freshman Representative twenty years as a public policy analyst. ${ }^{132}$ ) Seniority rules also offer a neutral means of allocating committee assignments that minimizes political infighting and prevents possible bias or other abuses from infecting such selections. ${ }^{133}$

Third, reforming Congress's seniority system poses a large practical problem. It would require action by a sitting Congress, ${ }^{134}$ which (absent term limits) has a self-interest in preserving the seniority system that helps assure its reelection. Significantly, even freshman legislators have an incentive to favor internal rules that confer seniority advantages (within reason) because such advantages make their own reelection more likely. ${ }^{135}$ The incentives are even greater for more senior legisla-

${ }^{131}$ A House majority approved a twelve-year term limit but rejected a six-year limit. See Providing for the Consideration of House Joint Resolution 73, the Term Limits Constitutional Amendment, HR Rep 104-82, 104th Cong, 1st Sess 3-4 (1995) (setting forth both amendment proposals). See Garrett, 81 Cornell L Rev at $628 \mathrm{n} 11$ (cited in note 9). Unless term limits make races more competitive (i.e., lower the reelection rate), a twelveyear term limit's reduction in median congressional tenure is predicted to be relatively small: from nine to seven years. See W. Robert Reed and D. Eric Schansberg, The House under Term Limits: What Would It Look Like?, 76 Soc Sci Q 699, 715 (1995).

${ }^{132}$ In Costa Rica, which has had the longest (forty-year) history of legislative term limits (a draconian version allowing just one four-year term), only 11 percent of legislators held no political office before being elected. John Carey, Parties, Incentives, and Term Limits in Costa Rica, in Grofman, ed, Legislative Term Limits 321, 324-25 (cited in note 5).

${ }^{133}$ Minority groups like the Congressional Black Caucus, for example, strongly favor seniority rules. See Congressional Quarterly, Inc, Congress A to Z: CQ's Ready Reference Encyclopedia 35-36 (CQ 1988).

${ }^{134}$ Indeed, the Constitution gives each House the power to determine its own rules, see US Const, Art I, \$ 5, cl 2, a power that perhaps even a federal statute could not restrict without violating this constitutional provision.

${ }^{13}$ Consistent with this, even in the seniority reforms that followed in the wake of large freshman classes in 1974 and 1994, see note 251, the ultimate change was quite modest. The 1974 Congress allowed only a caucus veto of chairs who took office by sen- 
tors who gain not only a reelection advantage but also a present increase in power. In contrast, before US Term Limits, voters had some hope that state-enacted term limits could circumvent a self-interested congressional veto. ${ }^{136}$ Indeed, if they had not been invalidated, the enactment of term limits by states holding a majority of congressional seats might have been the best way to sufficiently change the incentives of a majority of federal legislators to get them to adopt internal changes in seniority rules. ${ }^{137}$

As the above suggests, a legislator's clout turns not just on his own seniority but on the seniority of other legislators as well. A highly experienced legislator with a powerful committee chairmanship has a larger advantage over inexperienced colleagues with no chair than over those with middling experience and positions. Voters thus care about relative seniority as well as absolute seniority.

This raises a question about term limits, for while they limit the absolute tenure of legislators, they do not eradicate variations in seniority. For example, in a twelve-year term limit regime, a district with an incumbent having ten years of experience still has incentives to vote for that incumbent over a newcomer who must start from scratch. Term limits thus cannot eliminate the coercive pressure that relative seniority has in a system where legislators represent separate districts. However, term limits can lessen the pressure to vote for senior incumbents by limiting the possible size of the seniority disadvantage. This should set an upper bound on the ideological distance between electorates and their representatives. Assuming the level of total pork depends on the average tenure of legislators, term limits should also lessen that average tenure in a way that lessens the total amount of pork the legislature produces.

Political parties complicate this picture. For example, a senior incumbent might belong to a party expected to be out of power in the next legislature. In that case, a district might be able to increase its relative legislative clout by voting for a newcomer from the party expected to be in power. This point is true, though

iority, and this veto was exercised only three times in 1974 and zero times the next Congress. See Garrett, 81 Cornell L Rev at 662 (cited in note 9). In the 1994 Congress, Speaker Newt Gingrich declined to follow seniority in selecting committee chairs in only three instances. Id at 145 . Consistent with the proposition that such seniority reforms do not address the underlying cause of the seniority advantage, incumbent reelection rates increased, rather than decreased, after 1974. See Benjamin and Malbin, eds, Limiting Legislative Terms Table B-2 at 293 (cited in note 5).

${ }^{135}$ Now the Court's decision requires term limits to be adopted by a constitutional amendment procedure that gives Congress an effective veto. See Part I.B.4.

${ }^{137}$ See Part II.D. 
limited in the following ways. Even for legislators belonging to the minority party, seniority matters. A minority leader of a legislature probably has more clout than a freshman belonging to the majority party, especially if the minority has blocking power. Consider, for example, the strong influence of Ted Kennedy in the 1996 Republican Senate. Further, given uncertainty about which party will win, a senior legislator from the ultimately losing party can have more expected legislative clout at election time than a junior legislator from the winning party even if those belonging to the losing party have zero clout in the end. ${ }^{138}$ More important, there are limits to the ideological slack a district will endure. The effects described here are less likely to make a district elect someone from an ideologically incompatible party than to elect someone with divergent views within the same party. And as to ideological divergence within a party, the complication raised in this paragraph does not apply.

Nonetheless, the introduction of political parties does raise some interesting points. First, term limits may be less likely to shift which party a district votes for in general elections than to shift who it votes for in party primaries. Second, the seniority of incumbents from the minority party is less advantageous, and I would thus expect more turnover in that party's legislators. Consistent with this, the reelection rates of incumbent Republicans in Congress from 1970 to 1990 were lower than those of incumbent Democrats. ${ }^{139}$ Third, for the party in power, the effects can be mutually reinforcing. Once a party gains legislative power, the coercive effect of seniority helps create an expectation that all the other districts will keep the party in power. And that expectation further reinforces the pressure in each district to vote to retain the incumbent from the majority party. This helps explain why periods of party dominance over legislative houses (such as the Democratic dominance of the House from the 1950s to 1994) last longer than party dominance of presidential and gubernatorial offices.

Finally, one might object that seniority in a particular branch of the legislature is not what matters, but rather political experience and expertise generally. If so, term limits might be

${ }^{23}$ Suppose, for example, Party $X$ has a 60 percent chance of taking the House and Party $Y$ has a 40 percent chance. Candidate $x$ from Party $X$ will have a clout of 1.0 if his party wins; the more senior candidate $y$ will have a clout of 2.0 if her party wins. (Both have a clout of 0.0 if their party loses.) The expected clout of candidate $y$ is thus higher ( .8 to .6) than the expected clout of candidate $x$ even though Party $X$ is expected to win.

${ }^{15 y} \mathrm{~J} J \mathrm{hn}$ B. Gilmour and Paul Rothstein, Term Limitation in a Dynamic Model of Partisan Balance, in Grofman, ed, Legislative Term Limits 145, 160 (cited in note 5). 
perverse since they do not normally prevent a person who reaches her term limit in one house from running for election in the other legislative chamber. ${ }^{140}$ The flaw with this objection is that in fact the above explanations for the seniority advantage are almost entirely specific to the branch of legislature in which the incumbent serves. This goes most obviously for the formal advantages conferred by legislative rules. Spending twelve years as a member of the House of Representatives may help me gain a lot of political expertise, but when I move to the Senate I am still a freshman without seniority on committees. But even if the rules were reformed, those moving to a new legislative chamber would still not know the ins and outs of that chamber's procedures, have established contacts there, or possess expertise on how new colleagues are likely to prioritize options and which agenda will thus likely be favorable. Former Representatives who switch to the Senate therefore do not seem any more powerful than other freshman Senators. This explanation of the seniority advantage is thus perfectly consistent with term limits that are similarly branch-specific. ${ }^{141}$

2. The link between ideological distance and individual seniority.

For my first claimed benefit from term limits to be true, the seniority of individual legislators must correlate positively with ideological distance from their electorates. Why should this be so? One possibility is that, as term limits proponents often assert, time in the legislature is affirmatively corrupting of ideological values. ${ }^{142}$ But many doubt this, and a contrary intuition is that over time legislators should become better and better at matching the views of their electorate. Indeed, one can imagine an evolutionary process where those who fail to mirror their electorates are weeded out, meaning that those who survive to become senior legislators are those who mirror their electorates best. ${ }^{143}$

\footnotetext{
${ }^{140}$ See Garrett, 81 Cornell L Rev at 656-57 (cited in note 9) (stressing that term limits do not deter the progressively ambitious politician who moves from one term-limited office to another).

${ }^{14}$ The brandname advantages discussed in Part III are less branch-specific. But even they are somewhat specific in that a large part of that brandname advantage is the reputation for serving the district well and accurately reflecting its preferences. Still, the specificity is less, which may explain why term limits justified only by brandname advantages have tended to be applied to positions, such as governor or President, that would generally be considered the final capstone on a career rather than a likely stepping stone.

${ }^{142}$ See text accompanying note 10. See also Part IV.B.

${ }^{14}$ See John R. Lott, Jr. and W. Robert Reed, Shirking and sorting in a political mar-
} 
I thus do not rely on any claim that legislative seniority affirmatively causes legislators to want to diverge more from the views of their electorates. Rather I assume only that there are natural drifts in the views of both electorates and legislators, and that more senior legislators have more freedom to express that drift fully. Over time, the political preferences of the voters or the representative may change with intellectual currents, or the composition of the district may change with demographic shifts. For whatever reason, an ideological gap develops. This is true for both senior and junior legislators. But because the senior legislator has more legislative clout, voters will accept greater ideological slack without denying him reelection. ${ }^{144}$ Assuming all legislators take advantage of the degree of ideological slack presented to them, the senior legislator will exhibit more ideological distance from his electorate even if his true views do not vary any more from the electorate's than the views of a freshman legislator. Moreover, because senior legislators and their districts have had longer to drift from the ideological correspondence that first won the legislator the office, I would expect a greater distance in their true views as well.

We can all think of anecdotal examples on the topic. For example, Ted Kennedy and Strom Thurmond seem to have more extremely liberal and conservative ideologies than less senior Senators from the same or similar states. But is there any more systematic evidence? Yes. Joseph Kalt and Mark Zupan find that the longer a legislator's tenure, the less closely his voting behavior reflects the ideological preferences of his constituents. ${ }^{145}$ Steven Levitt finds that first-term Senators are more than twice as responsive to voter preferences as later-term Senators. ${ }^{146}$ Similarly, more powerful committee assignments correlate positively with ideological divergence in voting. ${ }^{147}$

In addition, many empirical studies have proven that incumbency confers advantages that give incumbents more room to

ket with finite-lived politicians, 61 Pub Choice 75, 76 (1989).

${ }^{14}$ Sometimes even a very senior legislator will be vulnerable when the ideological distance between him and his constituents becomes large enough to offset the value of his experience at providing governmental benefits. This may explain the remarkable ouster of House Speaker Tom Foley. But the more important lesson is just how remarkable such an ouster was. Unless a senior legislator mistakenly oversteps his bounds, he should be able to retain his office despite considerable ideological distance from his electorate.

"'Joseph P. Kalt and Mark A. Zupan, The Apparent Ideological Behavior of Legislators: Testing for Principal-Agent Slack in Political Institutions, 33 J L \& Econ 103, 11820, 126 (1990).

${ }^{14}$ See Steven D. Levitt, How Do Senators Vote? Disentangling the Role of Voter Preferences, Party Affiliation, and Senator Ideology, 86 Am Econ Rev 425, 436 (1996).

${ }^{13}$ Kalt and Zupan, $33 \mathrm{~J} \mathrm{~L} \mathrm{\&} \mathrm{Econ} \mathrm{at} \mathrm{121-22,} 126$ (cited in note 145). 
maneuver. Studies show that new legislators predictably experience a "sophomore surge," a large statistical vote gain between their election as challenger and their first election as an incumbent, even though they remain the same person. ${ }^{148}$ Further, when an incumbent announces his retirement, his party experiences a "retirement slump," a large statistical vote loss between the retiree's last election and the party's candidate in the next election. ${ }^{149}$ Indeed, parties are five times more likely to lose a seat they held the prior term if it is open than if they are running an incumbent. ${ }^{150}$ One recent study estimates the overall incumbency advantage, the increased vote percentage an incumbent party receives when it is running an incumbent legislator rather than a newcomer, at around 10 to 12 percent in $1988 .{ }^{151}$ If anything, this study underestimates the incumbency advantage by not including uncontested elections, where the incumbent's advantage may be so great that it scares away all potential challengers. ${ }^{152}$ In 1990 , 19.5 percent of House incumbents running faced no major party challenge at all. ${ }^{153}$

Some dispute this evidence, arguing that empirical studies show little evidence of ideological shirking by legislators and instead support the theory that evolutionary sorting results in senior legislators who share the same ideology as their constituents. ${ }^{154}$ But this argument is based mainly on evidence that re-

\footnotetext{
${ }^{148}$ Andrew Gelman and Gary King, Estimating Incumbency Advantage without Bias, 34 Am J Pol Sci 1142, 1149-50 (1990) (collecting sources).

${ }^{199} \mathrm{Id}$.

${ }^{150}$ Alexander Tabarrok, Term Limits and Political Conflict, in Grofman, ed, Legislative Term Limits 237, 237-38 (cited in note 5) (25.7 percent of open House seats lost, 5 percent of incumbent seats). Likewise, 42.7 percent of open Senate seats are lost while only $\mathbf{1 5 . 5}$ percent of incumbent seats are lost. Id.

${ }^{15}$ Gelman and King, 34 Am J Pol Sci at 1148, 1157-58 (cited in note 148). This vote percentage does not appear to vary much over the course of a legislative career, see John R. Hibbing, Careerism in Congress, in Lawrence C. Dodd and Bruce I. Oppenheimer, eds, Congress Reconsidered 67, 72 \& fig 3-2 (CQ 5th ed 1993), but this is hardly surprising. We would expect a candidate to take advantage of increased slack by diverging more from the electorate, meaning that a senior legislator might well have and exercise far more ideological slack but not win reelections by any higher margin.

${ }^{152}$ Gelman and King, 34 Am J Pol Sci at 1158-60 (cited in note 148).

${ }^{153}$ See text accompanying note 259.

${ }^{15}$ The main proponent of this view is John Lott. See Bruce Bender and John R. Lott, Jr., Legislator voting and shirking: A critical review of the literature, 87 Pub Choice 67, 68, $72-79$ (1996); John'R. Lott, Jr. and Stephen G. Bronars, Time series evidence on shirking in the U.S. House of Representatives, 76 Pub Choice 125, 126 (1993); John R. Lott, Jr. and Michael L. Davis, $A$ critical review and an extension of the political shirking literature, 74 Pub Choice 461, 479 (1992); Lott and Reed, 61 Pub Choice 75, 87 (cited in note 143); John R. Lott, Jr., Political Cheating, 52 Pub Choice 169, 183 (1987). This is surprising since Lott is one of the authors of a piece that argued term limits reduce ideological slack by replacing senior legislators with junior ones. Dick and Lott, $50 \mathrm{~J}$ Pub Econ at 11 (cited in note 7). These positions strike me as in unresolvable conflict-if there is no
} 
tiring legislators do not significantly change their voting behavior, at least not any more than legislators planning to run for reelection. ${ }^{155}$ That evidence is somewhat disputed..$^{156}$ But the bigger problem is that such evidence of an absence of final-term changes in legislator behavior does not contradict the evidence that ideological divergence increases with legislator tenure. ${ }^{157}$ There are at least two explanations that can reconcile both findings.

First, retiring legislators may simply feel obliged to carry out the promises they made when they ran in their last election. If so, what matters is not that they face no reelection but the degree of slack in the last election they ran. The slack operates prospectively rather than retroactively. Since there is little reason to think the degrees of slack between the last election and the penultimate one are very different, there is little reason to

ideological shirking, how can term limits reduce it? For an attempt to finesse the conflict, see id at 8 \& $\mathbf{n} 11$.

${ }^{155}$ See sources cited in note 154; James R. VanBeek, Does the Decision to Retire Increase the Amount of Political Shirking?, 19 Pub Fin Q 444 (1991). Typical is Lott and Bronars, 76 Pub Choice 125 (cited in note 154). It finds that from one term to the next, congressmen change their ideology from 7 to 15 points on various 100 -point scales, id at 129 , and that the correlation between a congressman's voting record in different terms declines the more separated by time those terms are, id at 131-32. This seems like a large change over time, but Lott and Bronars conclude from this evidence that congressional voting patterns remain remarkably stable over time" because the changes are no different for retiring and continuing legislators. Id at 133.

${ }^{15}$ Zupan finds that the magnitude of ideological divergence increases between the first and second years of the final term of a retiring legislator. See Mark A. Zupan, The last period problem in politics: Do congressional representatives not subject to a reelection constraint alter their voting behavior?, 65 Pub Choice 167, 172-76 \& $178 \mathrm{nn} 17,19$ (1990). But even Zupan finds that the overall divergence of retiring legislators in their final term is not significantly higher than that of nonretiring legislators running for reelection. Id at 176.

wh Some direct technical objections to one paper making such a finding are raised in Lott \& Davis, 74 Pub Choice at 462-63 (cited in note 154), which also argues that even if there is a statistically significant relationship between tenure and ideological divergence, it is not very large. See also Bender and Lott, 87 Pub Choice at 76, 79 (cited in note 154) (same); Lott and Bronars, 76 Pub Choice at 139-40 (cited in note 154) (same). This is a claim about the size rather than statistical significance of the correlation between tenure and ideological divergence. For reasons to think the measures underestimate the size of the correlation, see text accompanying notes 166-68. Note also that a failure to find a statistically significant correlation is not the same as proving there is no correlation; it simply means that we cannot say with great confidence (usually 90 percent or more) that any correlation is not accidental. Thus, a study that showed a strong correlation that was 89 percent likely to be more than an accident could come out as statistically insignificant because the affirmative proposition that a correlation existed could not be stated with 90 percent confidence. But the negative proposition that no correlation existed could be stated with even less (11 percent) confidence. In any event, Lott's position here is again hard to square with his position on term limits: if there is little if any correlation between tenure and ideological divergence, how could limiting tenure possibly reduce ideological divergence? 
think the retiring legislator should change his behavior very much, at least not any more than any legislator running for reelection, which is what the evidence finds..$^{158} \mathrm{~A}$ legislator should enjoy somewhat increased ideological slack every term, but this applies equally to legislators toward the end and beginning of their careers. None of this contradicts the evidence that ideological slack increases with tenure or suggests legislators should dramatically increase their ideological slack once they announce retirement.

Public choice scholars have missed this explanation because they have made "the virtually universal assumption that politicians keep promises to their constituents solely because of the threat of reelection." 159 But this assumption is dubious. Even within the assumption that legislators solely maximize their personal utility, they have many reasons to stick to campaign promises, including retaining the respect of their family, friends, supporters, or history in general. ${ }^{160}$ And we cannot dismiss the fact that people generally feel honor-bound to live up to their promises even if it does not bring them personal gain. ${ }^{161}$ After all, we have all left tips at restaurants even if we never plan to return to them because we implicitly promised to do so when we sat down.

Second, even if we adopt more cynical assumptions, we might see no change in retiring legislators' final terms precisely because their seniority has given them so much ideological slack that they don't have any further to go when the reelection constraint is removed entirely. ${ }^{162}$ After all, the legislators old enough to have reached retirement age are generally also senior enough to enjoy great ideological slack because of the collective action problems discussed above and the entry barrier problems detailed in Part III. And to get elected in the first place, politicians must begin with some ideological correspondence with their elec-

\footnotetext{
${ }^{1 *}$ See sources cited in notes 155-57. This theory has the added benefit of explaining why politicians ever announce their retirement before they run for reelection. Voters do not refrain from electing such politicians because they expect them to largely live up to their campaign promises.

${ }^{159}$ Lott and Reed, 61 Pub Choice at 87 (cited in note 143).

${ }^{160}$ Lott adjusts for the possibility that post-legislative employment might discipline how final-term votes are cast and generally (though not always) finds no significant correlation. See Lott, 52 Pub Choice at 176-79 (cited in note 154).

${ }^{163}$ Such honor is not inconsistent with the premise that senior legislators exercise ideological slack from their constituents because such slack is exercised to advance what the legislators believe to be right.

${ }^{122}$ Compare Levitt, 86 Am Econ Rev at 436 \& n 22 (cited in note 146) (finding secondterm Senators half as responsive to electorate preferences as first termers but no more responsive than higher-term Senators).
} 
torate. A significant amount of slack can thus allow them to vote their own preferences fully by their penultimate term and leave them with no further desire to change votes when they no longer face reelection. ${ }^{163}$

John Lott dismisses this second possibility because of evidence that, while they do not change their votes, retiring legislators do vote less frequently. ${ }^{164} \mathrm{He}$ thus concludes that they must be enjoying more slack but choosing not to exercise it to change their votes because they derived personal utility from the votes they cast in the past. But decreased attendance of retiring legislators may be due to lower energy or worse health rather than to increased slack. True, Lott finds that age and reported illness explain some but not all the decrease in attendance. ${ }^{165}$ Still, unreported illnesses and a more nebulous dropoff in energy are common causes of retirement that could easily explain the rest. In any event, greater changes in whether votes are cast than how they are cast are perfectly consistent with the first explanation noted above. Incumbents in their final election are likely to have made explicit promises on their political stances that they generally feel honor-bound to keep. But few candidates make promises about their future attendance records.

If anything, the empirical studies underestimate ideological slack for various reasons. First, they measure only recorded votes. ${ }^{166}$ But much ideological slacking is likely to take the form of failing to push for positions the electorate favors by making speeches, offering trades, twisting arms, and the like. ${ }^{167}$ Making

\footnotetext{
${ }^{1 \infty}$ Again, this explanation is consistent with politician announcements of retirement before upcoming elections. Because voters already value their legislator's seniority clout more than they disvalue the full exercise of the politician's ideological slack, such announcements do not dissuade voters from electing the retiring politician.

${ }^{164}$ See Bender and Lott, 87 Pub Choice at 75-76 (cited in note 154); John R. Lott, Jr., Attendance Rates, Political Shirking, and the Effect of Post-Elective Office Employment, 28 Econ Inquiry 133, 135 (1990); Lott, 52 Pub Choice at 181-83 (cited in note 154).

${ }^{15}$ Lott, 28 Econ Inquiry at 141 (cited in note 164).

${ }^{160}$ Thus, failure to attend congressional votes would not count as ideological divergence under their definition even though it would under mine. See Part II.A.1. Another oddity is that the studies rely almost exclusively on data from congressional races in 1976-78. See, for example, Lott, 28 Econ Inquiry at 136 (cited in note 164); Kalt and Zupan, $33 \mathrm{~J} \mathrm{~L} \mathrm{\&} \mathrm{Econ} \mathrm{at} 110$ (cited in note 145). Whether the same findings hold up in different periods or legislatures remains largely untested.

${ }^{15}$ Although most of these cannot be directly measured, there is evidence that, in addition to voting less, congressmen in their last term make fewer speeches, travel less, and offer fewer amendments and bills. See Rebekah Herrick, Michael K. Moore, and John R. Hibbing, Unfastening the Electoral Connection: The Behavior of U.S. Representatives When Reelection Is No Longer a Factor, $56 \mathrm{~J}$ Pol 214, 219-20 (1994). Unfortunately, the evidence does not enable one to determine whether this reflects a general lowering of effort or a selective lowering of effort for unfavored causes, though the range of issues on which bills are introduced is narrower in the final term. Id at 221.
} 
recorded votes contrary to the electorate's views (or one's past positions) is a less attractive means of exploiting slack since it is far more salient and easier for others to notice. Unfortunately, the degree to which representatives push their electorates' views is difficult if not impossible to measure. Second, the empirical studies define "ideological" in a way that lumps what I call ideological with what I call the distribution of governmental benefits. Thus, a legislator who better represents his district on the combination of ideological and benefit-distribution factors might score a lower divergency under the studies even though under my definition his "ideological" distance has increased as his provision of benefits has improved. Third, many studies define ideological divergence by consistency with various special interest indexes of congressional voting, such as the Americans for Democratic Action or the American Conservative Union. ${ }^{168}$ Ideological divergence on matters that are not of interest to those groups is thus left out of the picture.

Whatever we think of the empirical evidence, our normal means of resolving empirical conflicts about the state of the world when making changes to legislative rules is through the political process. And there is certainly enough evidence to make it rational for voters to believe ideological slack increases with legislative tenure. This suffices to answer the constitutional question: whether we should be constituted in a way that allows a majority of voters to set term limits if they wish.

Moreover, even if the empirical evidence did show that ideological slack does not increase with seniority, that would only rebut the collective action problem identified in Part II.A.1. The collective action problems identified in Parts II.A.2 and II.A.3legislative pork that is preferred individually but not collectively and collective trading to eliminate noxious legislators from other districts-would remain and be addressed by term limits.

3. The link between overall pork and seniority levels.

My second claimed benefit of term limits is that they will lower overall levels of legislative pork. ${ }^{169}$ Why should this be so?

\footnotetext{
${ }^{169}$ See, for example, Lott and Bronars, 76 Pub Choice at 128 (cited in note 154); Lott and Davis, 74 Pub Choice at 467-72 (cited in note 154); Lott, 52 Pub Choice at 171 (cited in note 154). Other studies define "ideological" divergence as the residual of whatever cannot be explained by various constituency interest variables. See Bender and Lott, 87 Pub Choice at 73, 79-80 (cited in note 154) (collecting sources). This creates the considerable problem that the ideological residual may just reflect constituency interest variables that were left out. Id at 73 .

${ }^{109}$ Mills also assumes it is at least prima facie plausible that term limits will lower the
} 
True, within a legislature of varying seniority, the more senior legislators should be more enthusiastic about pork than the junior ones since the senior ones get a larger share. ${ }^{170}$ But one cannot necessarily deduce from this that decreasing the average tenure of a legislature will decrease pork since the average pork share could remain the same. For that matter, why is pork ever enacted if its costs exceed its benefits?

There are two standard explanations of the pork phenomenon. The first is that the concentrated benefits of pork in a particular district are more salient and affect an easier-to-organize group than the costs of pork, which are diffusely spread throughout other districts. ${ }^{171}$ For example, a district's voters know whether its main employer has gone out of business, but voters from other districts cannot monitor each item in the governmen-

overall level of pork relative to general-interest legislation. See Mills, 10 Pub Affairs Q at 147 (cited in note 115). But unlike this Article, that is the only collective action benefit of term limits that he cites. Compare with Parts II.A.1; II.A.3. Further, his reasons for assuming term limits will reduce pork are unpersuasive. First, he equates undesirable pork with the distributable governmental benefits. See Mills, 10 Pub Affairs Q at 145, 147 (cited in note 115): "at least some such local economic benefits are pork, in the sense that they serve local interests while thwarting broader national ones" and "it oversimplifies only slightly to say that under our current system, each legislator gets as much as possible for her own district without regard to the national costs, so that voters' interests would probably be better served if [they] foreswore the pork that legislators without term limits provide." However, distributable governmental benefits that are nationally desirable can also drive the collective action problem, see note 116 and accompanying text, and there is no compelling reason to believe that a reduction in distributable governmental benefits generally will benefit voters. Second, Mills assumes for purposes of his prima facie case that legislators seeking reelection under term limits will have less incentive to enact pork. Id at 147. But that is refuted by the analysis in the text following this footnote. Third, his main argument is that term limits will produce more legislators in their last term who, not needing to be reelected, will enact less pork. Id. But he offers no persuasive reason to think that, prima facie, the benefits of unaccountability on pork would be outweighed by the disadvantage of unaccountability on all other political issues. See Part IV.C. Moreover, the actual validity (as opposed to prima facie plausibility) of this argument is undermined by evidence that voting behavior does not change in final terms. See Part II.B.2. If legislators did lessen their pursuit of pork in their final term, then voters would be less likely to elect legislators to that final term, so it is not surprising that legislators learn how to commit credibly to continued pork provision. Mills does not address the argument, put forth here, that lower legislative tenure selectively lowers the "ability to act on incentives to enact pork.

17u There is evidence that the longer they serve in office, the more likely both Republicans and Democrats are to favor spending bills. See James L. Payne, The Culture of Spending: Why Congress Lives Beyond Our Means, 81-87, 176-78 (ICS 1991). See also Will, Restoration at 61 (cited in note 10); W. Robert Reed and D. Eric Schansberg, Impact of Congressional Tenure Restrictions on Spending, in Grofman, ed, Legislative Term Limits 101, 111 (cited in note 5) (Tenure had small but statistically significant effect on ratings by National Taxpayers Union.). To be sure, not all spending is pork. But while different views about the desirable level of spending can explain the different spending levels between the parties, it is hard to see why they would explain an increase in spending over time by individuals in both parties.

${ }^{\text {"n }}$ See Elhauge, 101 Yale $L \mathrm{~J}$ at 41 (cited in note 79). 
tal budget to see if it includes a wasteful subsidy to prop up that employer. Moreover, while the district's legislator can credibly claim credit for pork benefiting her district (who else would be for it?), it is hard to single her out for blame in approving pork in other districts. Thus, a legislator's electoral chances are far more benefited by getting pork in her district than they are hurt by allowing pork in other districts. A legislator will accordingly approve pork in other districts in exchange for other legislators' approving pork in her district, improving the odds of reelection for everyone though impoverishing the nation.

The second explanation is that pork reflects a "universalistic" norm for reducing cycling and agenda-setting problems with majority rule. ${ }^{172}$ Recall that even though each individual legislator rationally ranks the policy options, a legislative majority can cycle between them, thus producing opportunities for agenda, manipulation. ${ }^{173}$ The universalistic norm tries to reduce cycling and agenda manipulation by sharing agenda-setting power among all members, giving each power to select policy in the area of most concern to her district through a norm of mutual deference. Each member thus naturally favors her district with pork in those areas in which she has the power to select policy.

However it gets started, pork is hard to stop because of a collective action problem among districts. Even if each district prefers to end pork barrel politics altogether, it knows that a decision to virtuously refrain from it will cost the district its normal share of pork and have little effect on the overall level of pork. The other districts will continue to provide pork to each other, and the lower costs from not providing pork to the district that opts out will be shared among all the districts, whether they opt out or not. Thus even a legislator who perfectly represented the interests of his district would continue to provide pork under these circumstances. Each district individually wants pork even though collectively they would like to end it. ${ }^{174}$

These motivations for pork are a byproduct of territorially elected legislators and/or cycling problems inherent in majority

\footnotetext{
${ }^{172}$ See, for example, Barry R. Weingast, A Rational Choice Perspective on Congressional Norms, 23 Am J Pol Sci 245, 250-55 (1979); Emerson M.S. Niou and Peter C. Ordeshook, Universalism in Congress, 29 Am J Pol Sci 246, 256-57 (1985).

${ }^{173}$ See text accompanying notes $129-30$.

${ }^{174}$ One might imagine a collective agreement to refrain from providing pork. But pork is impossible to define in an enforceable way. Further, such an agreement would only be enforceable against future legislatures if it were incorporated into the Conștitution. In any event, whether done through constitutional amendment or statute, a collective agreement to curb pork can be obtained only by overcoming a legislative veto that legislators have every incentive to exercise to preserve their incumbency advantage.
} 
rule, neither of which term limits changes. ${ }^{175}$ Thus, the incentives to promise or provide such pork would seem to be no lower for challengers seeking initial support and newcomers seeking reelection before they hit their term limit than they are for longterm incumbents.

But legislative tenure should affect the ability to act on these motives by making it harder to maintain the reciprocal logrolling and mutual deference needed to enact pork. Voting for pork in other districts carries this risk: if the other legislators do not reciprocate by voting for pork in your district, then you make your district worse off for nothing. Legislators will thus approve each other's pork only if they can strike and enforce a mutually beneficial deal or pattern of logrolling. Term limits disrupt this pattern in two ways. ${ }^{176}$ First, they limit the prospective time in office. This makes it less likely that the other legislator will be around to carry out his end of the bargain. More generally, the shorter and more uncertain the period of future repeat play, the lower the incentive to cooperate in the present. ${ }^{177}$ Second, term limits lower average past tenure. The less time legislators have served together, the less familiar they will be with each other, the more difficulty they will have striking deals, and the less they can develop reputations for fulfilling or enforcing deals. Likewise, the mutual deference needed to adopt a universalistic norm is undermined by reducing the repeated experience and trust that seniority provides.

In addition, at least some pork is so egregious (it confers a much larger cost than the benefit to the favored district) that only a legislator with an extremely large seniority advantage could ever get it through. ${ }^{178}$ An extremely senior legislator can obtain such egregious pork because he can offer or threaten far

\footnotetext{
${ }^{12}$ Getting rid of district representation might be an alternative reform that would reduce pork. However, because representatives would cover a much larger area, they would be less able to adjust for regional variations, and voters would have more difficulty monitoring them. The lower pork would thus likely come at the cost of increasing voters' ideological distance from their representatives.

${ }^{n}$ See generally Reed and Schansberg, Impact of Congressional Tenure Restrictions, in Grofman, ed, Legislative Term Limits at 101-02 (cited in note 170).

${ }^{m}$ See Peter Bernholz, On the stability of logrolling outcomes in stochastic games, 33 Pub Choice 65, 75-78 (No 3 1978). At the extreme, term limits eliminate the incentives to cooperate altogether by creating an incentive to defect in the final period, knowledge of which creates an incentive to defect in the penultimate period, which by extension unravels all cooperation back to the first period. See L.G. Telser, A Theory of Self-enforcing Agreements, $53 \mathrm{~J}$ Bus 27, 29 (1980).

${ }^{17}$ For example, Senator Robert Byrd brought $\$ 5$ billion in federal spending to West Virginia in three years, including transferring the national fingerprinting lab of the F.B.I. and moving a significant part of the C.I.A. staff. See Calamita, Comment, $8 \mathrm{~J} \mathrm{~L} \mathrm{\&} \mathrm{Pol} \mathrm{at}$ 575 (cited in note 9); Hills, 53 U Pitt L Rev at 145 n 196 (cited in note 61).
} 
more in return than a junior legislator can. Because term limits lower the range of differences in tenure, they also lower the possible difference in relative seniority. This should prevent some of the most egregious pork from being enacted.

Still, because the premise that seniority affects overall pork levels is more contestable than the observation that seniority affects the distribution of any level of pork, I stress that the argument for term limits stands without it. Even if term limits have no effect on the total level of pork, they still have the salutary benefits of reducing the pressure to vote for ideologically divergent senior incumbents and of allowing districts to effectively engage in bargains that oust senior incumbents noxious to other districts.

But, wouldn't decreasing legislative tenure also reduce the amount of nonpork governmental benefits? Probably less so. By definition, nonpork is approved not because of the concentration of its benefits on some districts but because the political forces in favor of it are generally stronger than those opposed to it. It is thus far more likely that a majority of legislators will independently favor the nonpork no matter what the other legislators do. Nonpork accordingly depends less than pork on the sort of ability to strike and enforce logrolling deals that higher overall legislative tenure enhances. Sometimes nonpork will be favored by only a minority of legislators, who will thus have to strike a deal with other districts. But it should be somewhat easier to do so because, the larger the ratio of benefits to costs, the greater the number of districts likely to be benefited and the more they can offer in a deal.

Moreover, some factors suggest less senior legislators will enact more nonpork. First, they may have more time to spend enacting nonpork if they spend less time on pork. Second, without term limits, highly senior legislators can often use their great legislative clout to block nonpork legislation. By reducing the divergence in legislative clout, term limits lessen the likelihood that a minority of legislators have the clout to block the wishes of a majority coalition.

Nonetheless, it remains possible that a lower average legislative tenure might cause some, even if relatively smaller, reduction in nonpork. But not all nonpork is desirable in the sense that its benefits exceed its costs, under whatever normative measure one cares to use. ${ }^{179}$ Some is undesirable, perhaps because it is pushed by special interest groups wielding dispropor-

${ }^{179}$ See Part II.A.2. 
tionate influence across all districts. ${ }^{180}$ Thus, even if nonpork is mostly desirable, the fact that it is a mixed bag coupled with the fact that its level is less affected by legislative tenure suggests that any decline in nonpork is likely to be normatively offset by the decline in the indisputably undesirable pork. If nonpork is mostly undesirable, then the decline in its level merely adds to the desirability of term limits.

This helps explain what to some has seemed an inexplicable tendency for leadership views on term limits to split along liberal-conservative lines. While term limits supporters have included such left-liberal figures as Jerry Brown, Ralph Nader, Bob Kerrey, Anne Richards, Paul Wellstone, Douglas Wilder, and Paul Tsongas, liberal leaders are generally less supportive than conservatives. ${ }^{181}$ Why should this be when on their face term limits are ideologically neutral? On the other hand, if term limits are just a matter of liberal versus conservative politics, why do term limits attract far more votes than conservatives generally do? After all, the 75 percent of Americans who favor term limits in polls ${ }^{182}$ is much higher than the percentage ever voting Republican.

The analysis above provides an answer. Term limits decrease ideological divergence, pork levels, and (perhaps) nonpork levels as well. Conservative normative baselines attach less positive value to governmental benefits and more negative value to governmental costs than liberal ones, thus leading conservatives to classify more government action as pork and more nonpork as undesirable. Conservatives are accordingly likely to find all three effects positive, making term limits an unambiguous boon. ${ }^{183} \mathrm{Lib}$ erals would find the first two effects desirable but not the last, and would find the size of the second positive effect smaller than conservatives since they classify fewer governmental benefits as pork. The conflicting effects are likely to split liberal leaders, as indeed they have been split in practice. But the first two effects may well dominate if, as I predict, any decline in nonpork is

\footnotetext{
${ }^{180}$ See Part IV.B.1.

${ }^{1 *}$ See Garrett, 81 Cornell L Rev at $628 \mathrm{n} 12$ (cited in note 9) (collecting sources noting opposition of leading Democrats, and support in Republican platform and Contract with America).

${ }^{\mathrm{k} \times}$ See Calamita, Comment, $8 \mathrm{~J} \mathrm{~L} \mathrm{\&} \mathrm{Pol} \mathrm{at} 589$ (cited in note 9). See also Benjamin Sheffner, Without Hope of Win, Term Limits Backers Maneuver for a Vote This Fall in the Senate, Roll Call 5 (July 27, 1995) (74 percent).

$\bowtie$ Note that conservatives with the goal of reducing nonpork levels by lowering average legislative tenure cannot achieve it through ordinary voting because it too poses collective action problems. Such a goal is thus consistent with their vote for both incumbents and term limits.
} 
small. And in fact typical polls show that among voters, as opposed to leadership, support for term limits among Democrats (71 percent) and Independents (78 percent) is only marginally smaller than support among Republicans (79 percent). ${ }^{184}$

Another explanation is partisan strategy: that Republican leaders favored term limits only because they did not control Congress and thought term limits would improve their odds. But this explanation is hard to square with the fact that most Democrat legislators continue to oppose term limits now that they are in the minority and most Republican legislators and voters continue to support them even though they are now in the congressional majority. Further, term limits were pushed even in states in which Republicans had legislative majorities. ${ }^{185}$ Indeed, 45 percent of term limits bills were sponsored by the party out of power in the state legislature. ${ }^{186}$ And Democrat voters were marginally less likely to vote for term limits than Republican voters regardless of which party controlled the legislature. ${ }^{187}$

A related partisan strategy theory focuses not on the effect of term limits on reelections during the term limit period, but on the fact that term limits create open seats when they oust incumbents. This theory points out that, regardless of whether it currently holds a majority, a party can do better with term limits if it does worse than the other party when its incumbents are running but better than the other party when open seats are contested. ${ }^{188}$ And empirically, this was true for Republicans in Congress from 1984 to $1990 .{ }^{189}$ But it is hard to put too much stock in this because the same relationship does not hold over a longer

${ }^{184}$ See Calamita, Comment, $8 \mathrm{~J} \mathrm{~L} \mathrm{\&} \mathrm{Pol} \mathrm{at} 589$ (cited in note 9). Support is also not very different among blacks ( 72 percent) and whites ( 75 percent), and actually a little higher among women (76 percent) than men (73 percent), among elderly (84 percent) than young ( 73 percent), and among the poor ( 77 percent) than the rich (71 percent). Id. See also Sheffner, Roll Call at 5 (cited in note 182) (noting support across demographic groups); John H. Fund, Term Limitation: An Idea Whose Time Has Come, in Benjamin and Malbin, eds, Limiting Legislative Terms 225, 225 (cited in note 5) (quoting CBS political director as stating he had "never seen an issue on which there was so little demographic variation"); id at 227 (earlier poll showing only 5 percent difference in percentages of liberals and conservatives for term limits).

${ }^{185}$ See, for example, Calamita, Comment, 8 J L \& Pol at 589-90 n 158 (cited in note 9) (Colorado); Daniel Friedman and Donald Wittman, Why voters vote for incumbents but against incumbency: A rational choice explanation, $57 \mathrm{~J}$ Pub Econ 67, 77 (1995) (Wyoming).

${ }^{18 \times}$ Benjamin and Malbin, Term Limits for Lawmakers, in Benjamin and Malbin, eds, Limiting Legislative Terms at 7 (cited in note 12).

${ }^{187}$ See Keith Boeckelman and Gina Corell, An Analysis of Term Limitation Elections, in Grofman, ed, Legislative Term Limits 185, 190 (cited in note 5).

See Gilmour and Rothstein, Model of Partisan Balance, in Grofman, ed, Legislative Term Limits at 156 (cited in note 139).

${ }^{1 \times}$ Id at 159-60. No data are offered for state races. 
time span. From 1970 to 1990 , or from 1954 to 1990, Democrats were far better at winning open seats than Republicans were. ${ }^{190}$ Republicans interested in term limits for partisan advantage in 1990 would thus have had to be gambling that the prior six years offered a better forecast of the future than longer time periods.

Moreover, because the open-seat theory claims an effect not in each election but only in the open-seat elections following the last term under term limits, the effect is limited. The theory's proponents themselves estimate that twelve-year term limits would gain Republicans four seats in a 435 -member Congress. ${ }^{191}$ It seems doubtful that minor pickup could be the main motivator for the term limits movement. Nor does the theory explain why, if advantaging Republicans were the main motive, support for term limits remains so high among Democrats. After all, in state legislatures, 44 percent of term limits bills were sponsored by Democrats. ${ }^{192}$ And Democrat voters are almost as likely to support term limits in polls and elections as Republicans. ${ }^{193}$ What might motivate them is left unexplained by the partisan strategy theory.

\section{Alternative collective agreements.}

The existence of a collective action problem does not necessarily mean a particular collective agreement is justifiable. There may be alternative, less restrictive, means of collective coordination. If voters in different districts could reach implicit agreements to get rid of only incumbents who are ideologically diver-

${ }^{190}$ Id (1970 to 1990); Will, Restoration at 218 (cited in note 10) (1954 to 1990). Democrats did, however, do better in incumbent races even in longer timespans. See Gilmour and Rothstein, Model of Partisan Balance, in Grofman, ed, Legislative Term Limits at 160 (cited in note 139). The authors do not, however, explore why this might be so. The analysis here suggests that it is either because being in the majority party exacerbates incumbency advantages, see text accompanying note 138, or because Republicans are less likely to favor spending on distributable governmental benefits and thus their incumbency confers less of an advantage, see Part II.B.2. Evidence from how incumbent Republicans do in the 1996 election may enable us to choose between these hypotheses.

${ }^{29}$ See Gilmour and Rothstein, Model of Partisan Balance, in Grofman, ed, Legislative Term Limits at 164 (cited in note 139) (based on long-term data from 90th-100th Congress).

${ }^{192}$ Benjamin and Malbin, Term Limits for Lawmakers, in Benjamin and Malbin, eds, Limiting Legislative Terms at 7 (cited in note 12).

${ }^{\mathrm{N}: 3}$ See text accompanying note 184 (noting polls showing 71 percent Democrat support, 79 percent Republican); John David Rausch, Jr. and Gary W. Copeland, Term Limits in Oklahoma, California, and Colorado in 1990, in Grofman, ed, Legislative Term Limits 199, 208-10 (cited in note 5) (One California term limits proposal got 50 percent of Democrat votes and 51 percent of Republican votes; Colorado term limits got 63 percent of Democrat votes, 73 percent of Republican votes; Oklahoma term limits got 73 percent of Democrat votes, 79 percent of Republican votes.). 
gent, pork-providing, or highly noxious to other districts, they could gain the benefits of term limits without suffering as often from having novices in office.

However, such agreements would be impossible to reach, much less enforce. Too many voters would have to be involved to reach any collective agreement. Moreover, because voting is simultaneous, involves massive numbers of participants, and is by secret ballot, voters in one state or district cannot observe the actions of voters in another district before making their choice. Hence they could not know whether any such implicit agreement was being kept by the other districts until after the election. Nor would members in such a diffuse group have reputational effects, strategic interdependence, or institutional arrangements to insure cooperation.

Term limits are a second-best solution to this problem. Because they offer a concrete prospective standard, collective agreement to term limits through state ballot initiatives is possible. And enforcement requires no ongoing monitoring by other voters or simultaneous coordination, but just the application of a simple rule. The downside is that term limits are overinclusive and underinclusive. Overinclusive because they sometimes screen out senior incumbents who are ideologically compatible with their districts and not prone to pork provision or noxious to other districts. Underinclusive because collective action problems remain that impose some pressure to vote for pork-providing incumbents despite some ideological divergence. But all legal rules are over- and underinclusive. ${ }^{194}$ And since we cannot hope to achieve the first-best solution, it hardly serves as a meaningful standard for critique. Reducing the magnitude of ideological slack and amount of total pork more than suffices to justify term limits.

Alternatively, we might try to tackle particular problemslike pork-with arguably more tailored remedies. But pork is extremely difficult to define, since it requires a common normative baseline for measuring the benefits and costs of legislation nationwide and within districts. Moreover, procedural remedies like the line item veto may not be so well-tailored after all. An executive can, after all, use the line item veto when pork is not involved and refrain from using it when pork is involved. It too is thus under- and overinclusive. Indeed, some analysts argue that

\footnotetext{
${ }^{194}$ See generally Stephen McG. Bundy and Einer Elhauge, Knowledge about Legal Sanctions, 92 Mich L Rev 261, 268-79 (1993); Einer Elhauge, The Triggering Function of Sale of Control Doctrine, 59 U Chi L Rev 1465, 1495-97 (1992).
} 
the line item veto does not reduce legislative pork but merely shifts power from the legislative to executive branch. The main reason is that executives seeking votes for a bill have incentives to promise not to exercise the line item veto against an individual legislator's pork if that legislator will support the bill. ${ }^{195}$ In any event, even if the line item veto would reduce pork levels somewhat, that does not eliminate the advantage of reducing them further with term limits. Nor would it negate all the other advantages of term limits discussed in Parts II and III.

Periodic redistricting might seem another alternative measure. But it would be disruptive and would also not be possible for all offices, such as U.S. Senators. Moreover, though we would expect it to result in the more frequent ouster of legislators, that is because they would have a harder time coming close to the political views of shifting electorates. There would still be seniority advantages and thus the penalty for rejecting a senior legislator would remain. Indeed, studies have shown that the decrease in competitiveness in legislative races has been no higher in states that redistricted than in states that did not, thus suggesting that current gerrymandering is not the main cause of the decline in competitiveness. ${ }^{196}$

\section{Variations Among Districts, Eras \& Political Jurisdictions}

Not all districts support term limits and some do so more vociferously than others. Nor are term limits equally popular at every time in history or in every state or nation. If we extend the above analysis by allowing for differences in certain features, we can help predict and explain such variations. Most of what follows is also derived mathematically in the Appendix.

1. Varying districts.

My basic model assumed all districts were similar, but obviously this does not hold. Most noteworthy, districts vary in the seniority of their representatives. They may also vary in how much they care about ideological divergence compared to gov-

\footnotetext{
"See, for example, Maxwell L. Stearns, The Public Choice Case Against the Item Veto, 49 Wash \& Lee L Rev 385, 417-18 (1992).

${ }^{1: T}$ See Charles R. Kesler, Bad Housekeeping: The Case against Congressional Term Limits, in Benjamin and Malbin, eds, Limiting Legislative Terms 241, 246 (cited in note 5). Moreover, any one state has collective action disincentives to redistrict its senior federal legislators. See Part III.D. With term limits, it became possible to coordinate parallel efforts in multiple states because term limits offered a six- to twelve-year coordination period. See Part II.D. But such a long coordination period is not possible with redistricting because the new districts take effect immediately after each census.
} 
ernmental benefits, in how much of the costs of pork they bear, and in the proportion of nonpork they deem socially desirable.

A district with less senior than average representation should favor term limits for two separate reasons. First, as with all districts, term limits reduce the pressure to vote for an ideologically divergent incumbent. Although a junior incumbent should be less ideologically divergent than more senior incumbents in other districts, a district is penalized for losing any degree of seniority it has. Moreover, the penalty is larger the greater the seniority of the other members because what determines pork distribution is relative seniority. ${ }^{197} \mathrm{~A}$ newcomer thus suffers a lower seniority disadvantage with term limits than without them. Accordingly, even if a district's incumbent has less tenure than the maximum a term limit would set, term limits still decrease the district's ideological slack by limiting the seniority of other districts' legislators and thus reducing the size of the penalty the district would suffer if it ousted its own legislator. This diminished slack need not result in the ouster of an ideologically divergent incumbent. Often, it will instead result in an ideological shift by that incumbent to take account of her lowered slack. Either way, the district benefits from lowered ideological divergence.

Second, a district with less senior than average representation receives less than an average share of governmental benefits. Term limits will bring its seniority and share of governmental benefits closer to average. This makes the district better off even if it does not experience or care about ideological divergence and even if decreased seniority does not decrease the overall level of pork. ${ }^{198}$ A district can thus find affirmative value in getting rid of senior representatives from other districts even if term limits leave the district no happier with its own representation. ${ }^{199}$ This helps explain why pro term-limits advertising in many districts often targets a few prominent legislators from other districts. In

\footnotetext{
${ }^{197}$ See Part II.B.1.

${ }^{198}$ See also Appendix. If decreased average legislative tenure does decrease the overall level of pork, that feature is all the more attractive to such districts because they suffer most from high pork levels.

${ }^{199}$ See Elhauge, Wall St $J$ at A14 (cited in note 115). See also Friedman and Wittman, $57 \mathrm{~J}$ Pub Econ at 70-73 (cited in note 185) (noting this motivation for term limits). In contrast to this Article, Friedman and Wittman assume that the only motive for term limits is to redistribute power (here from senior districts to junior districts) and ignore the ways in which term limits can solve various collective action problems and make government work better to the benefit of all districts. See id at 81 . They thus can explain some of the variation in support in different districts but not the overall level of support. See id at $\mathbf{8 2}$. See also id at 72, 75 (conceding that effect of district seniority is weak, on order of 1 to 3 percent).
} 
California, for example, term limits proponents pitched term limits statewide as a way of getting rid of Assembly Speaker Willie Brown, so much so that his legal challenge to term limits claimed they were a "bill of attainder."

Whether a district with more senior than average representation will favor or oppose term limits is less clear. On the one hand, it suffers even greater ideological slack than districts with more junior representation. Thus, term limits would confer a greater benefit on it. On the other hand, a senior district would suffer some positive costs because term limits would reduce its share of any governmental benefits distributed by tending to equalize seniority. Whether the benefit outweighs the cost depends on the particular district. ${ }^{201}$ Consistent with these conflicting effects, senior districts tend to oppose term limits more often than junior districts, but not by a very large margin. One study of the California vote for term limits, for example, found that districts with senior legislators were only 1 to 3 percent less likely to vote for term limits than districts with junior legislators. ${ }^{202}$

Where a senior district falls will likely depend on how much it cares about ideological fit compared to pork and how much of the costs of pork the district pays. If it does not care about ideological fit at all, it will enjoy no benefit from reducing ideological divergence. It will thus surely be a net loser if overall pork levels are unaffected by term limits. If term limits reduce pork levels, the loss of its above-average pork share may be offset by the greater efficiency. But not always. And even when it is, the overall result depends on what share of pork costs it pays. If, for example, a district pays little of the taxes funding pork, the district does not benefit from lower overall pork levels for it is a net gainer from pork generally and not just in its district. Poor districts might disproportionately have this profile if they pay little taxes and disproportionately value pork because they do not have the luxury of expressing purely ideological benefit at the expense

See Charles M. Price, The Guillotine Comes to California: Term-Limit Politics in the Golden State, in Benjamin and Malbin, eds, Limiting Legislative Terms 117, 121, 125 (cited in note 5).

"See also Appendix (making same point mathematically). Even if the collective action problems alone would make senior districts on balance less enthusiastic than junior districts about term limits, entry barrier problems should offset this to some extent because they make term limits more attractive to senior districts. See text accompanying notes 290-93.

${ }^{2 / 2}$ See Friedman and Wittman, $57 \mathrm{~J}$ Pub Econ at 75 (cited in note 185). One caveat about this evidence: because the term limits were prospective and thus did not oust any legislators for six years, it is not clear that the districts with senior legislators in 1990 when term limits were enacted expected to have senior legislators in 1996. 
of economic interest. ${ }^{203}$ Richer districts, in contrast, might disproportionately have the opposite profile: paying a higher than average share of taxes and thus pork costs and gaining a belowaverage benefit from pork compared to ideological correspondence. This might further explain why, even though their ideological content is neutral on the surface, term limits are more likely to be opposed by liberals than by conservatives. ${ }^{204}$

In any event, a district with relatively little ideological concern and a low share of pork costs can stand a much larger ideological gulf between it and its representative, and would thus be expected to have very senior representation and a large share of pork. It would also predictably oppose term limits and do worse under them. But the district imposes clear externalities on other districts. It wants the type of representation it gets only because the costs of it are borne by the other districts. Those other districts might thus turn to term limits to rid themselves of this externality.

Finally, districts might vary in their beliefs about the proportion of nonpork that is socially desirable. Districts that think the proportion is low (the conservative districts) are more likely to favor term limits. ${ }^{205}$ Districts that think the proportion is high (the liberal districts) are more likely to oppose term limits, but may well still be attracted because they find any effect on nonpork levels offset by the combination of the declines in pork and ideological divergence. ${ }^{206}$

\section{Varying times and jurisdictions.}

Legislative term limits have not been equally popular in every political jurisdiction or every historical period. They have passed in some states and not others. They have been popular in the United States but in few other nations. ${ }^{207}$ And they have only

\footnotetext{
${ }^{203}$ Elderly districts might have similar incentives if they receive much pork but pay little in taxes.

${ }^{20}$ See also Part II.B.3. Another possible connection is that (perhaps because the Voting Rights Amendment attempts to secure safe seats for minorities) reelection rates are higher for blacks than whites. See Daniel A. Farber, Review, Black Faces, Black Interests: The Representation of African Americans in Congress, 11 Const Comm 613, 619-20 (1995) (reviewing Carol M. Swain's Black Faces, Black Interests). This should tend to make black representatives more senior. Of course, for the reasons noted above, senior districts will not necessarily oppose term limits but they are more likely to do so than junior districts. See also note 184 (noting that support for term limits is only slightly lower among blacks (72 percent) than whites ( 75 percent)).

${ }^{205}$ See Part II.B.3.

${ }^{20}$ Id.

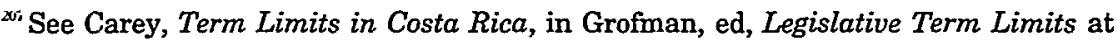
321 (cited in note 132) (The only nations with legislative term limits are Costa Rica,
} 
recently become popular in the United States. Before 1990, no state had legislative term limits. From 1990 to 1995, twenty-four states enacted them. What explains this variation and timing?

The ideological slack reduced by term limits is higher the longer the prevailing levels of incumbent tenure because such long tenures increase the penalty in each district of replacing an incumbent. ${ }^{208}$ I would thus expect overall enthusiasm for term limits to be higher when tenure and reelection levels are high. And those levels were steadily increasing in the years leading up to 1990 . In the state legislatures, turnover rates that as late as the 1960s had been in the 30 to 40 percent range dropped to 16 to 20 percent by 1988, and reelection rates often exceeded 90 percent. ${ }^{209}$ In some states, turnover was far lower. In Colorado, one of the first three states to enact legislative term limits in 1990, no state senator had lost reelection in ten years. ${ }^{210}$ In another of these three states, California, only 3 out of 273 had lost in the prior six years-none in $1988 .{ }^{211}$

In Congress, reelection rates were even higher than in the average state legislature. In the period before 1990, House reelection rates were over 90 percent for sixteen years running and over 95 percent for eight years running. ${ }^{212}$ This was unprecedented in U.S. history. Indeed, in the 150 years before 1968, the reelection rate had never once exceeded 95 percent. ${ }^{213}$ The term limits movement took off after the 1988 elections, when an alltime high of 98 percent of House incumbents running were reelected, a rate higher than reelection rates in the old Soviet

Mexico, Ecuador, and the Philippines.).

${ }^{*}$ See Appendix.

${ }^{20 s}$ Benjamin and Malbin, Term Limits for Lawmakers, in Benjamin and Malbin, eds, Limiting Legislative Terms at 5 (cited in note 12); David H. Everson, The Impact of Term Limitations on the States: Cutting the Underbrush or Chopping the Tall Timber?, in Benjamin and Malbin, eds, Limiting Legislative Terms 189, 191, 194 (cited in note 5); Fund, Term Limitation, in Benjamin and Malbin, eds, Limiting Legislative Terms at 23233 (cited in note 184); Gary F. Moncrief, et al, For Whom the Bell Tolls: Term Limits and State Legislatures, in Grofman, ed, Legislative Term Limits 119, 127 (cited in note 5).

${ }^{210}$ Benjamin and Malbin, Term Limits for Lawmakers, in Benjamin and Malbin, eds, Limiting Legislative Terms at 5 (cited in note 12); Fund, Term Limitation, in Benjamin and Malbin, eds, Limiting Legislative Terms at 233 (cited in note 184).

${ }^{211}$ Benjamin and Malbin, Term Limits for Lawmakers, in Benjamin and Malbin, eds, Limiting Legislative Terms at 5 (cited in note 12); Benjamin and Malbin, eds, Limiting Legislative Terms appendix A at 276 (cited in note 5).

${ }^{212}$ Benjamin and Malbin, eds, Limiting Legislative Terms table B-2 at 293 (cited in note 5).

${ }^{213}$ Id at 291-93. There were a couple of years in our early history when the reelection rate exceeded 95 percent but in those years voluntary rotation was more prevalent and no more than sixty-eight representatives ran for reelection. Id at 291. The overall turnover rate in those years ranged from 30 to 46 percent, which compares to 8 to 12 percent turnover from 1983 to 1991. 
Politburo. ${ }^{214}$ Indeed, during the 1988 to 1990 period a federal legislator was statistically almost as likely to be sentenced to prison as to lose reelection: five were sent to prison, six lost reelection. ${ }^{215}$ And of those six who lost, five were under some sort of ethical cloud. ${ }^{216}$ Turnover was higher in Britain's House of Lords. ${ }^{217}$

Such high reelection rates naturally result in high levels of tenure and thus high penalties for ousting incumbents noncollectively. Between 1953 and 1991, the average tenure went from 9.8 to 12.4 years in the House, and from 8.5 to 11.1 years in the Senate. ${ }^{218}$ The effects at the highest levels of seniority were even more striking. The House went from 119 representatives who had served 12 or more years to $198 .{ }^{219}$ (Before this century, that number had never exceeded $23 .{ }^{220}$ ) The Senate went from 19 senators with 12-years seniority to $49 .{ }^{221}$ The early 1990 s thus marked the first time in history that the number of legislators with 12-years seniority was nearly 50 percent in both chambers.

Conversely, the enthusiasm for term limits should diminish the lower reelection and turnover rates are. This is one reason the term limit movement predictably lost steam after many freshmen took office in the 1994 congressional election. And it may be why the constitutional framers were less interested in term limits. At that time, tenure in the new Congress was zero, and past turnover had been high. ${ }^{22}$ Moreover, the strong norm, following the example of George Washington and Thomas Jefferson, was to voluntarily rotate out of legislative office. ${ }^{223}$ Through-

\footnotetext{
${ }^{214}$ Calamita, Comment, $8 \mathrm{~J} \mathrm{~L} \&$ Pol at 568 (cited in note 9); California Ballot Pamphlet, reprinted in Benjamin and Malbin, eds, Limiting Legislative Terms appendix A-5 at 275-76 (cited in note 5). The first term limits initiatives were passed in 1990, the first election year after the 1988 elections.

${ }^{215}$ Lee Iacocca, We Can't Even Throw the Rascals Out, LA Times B7 (May 18, 1990).

${ }^{216}$ See Fund, Term Limitation, in Benjamin and Malbin, eds, Limiting Legislative Terms at 230-31 (cited in note 184).

${ }^{217}$ See California Ballot Pamphlet, reprinted in Benjamin and Malbin, eds, Limiting Legislative Terms appendix A-5 at 275-76 (cited in note 5).

${ }^{218}$ See Will, Restoration at 74-76 (cited in note 10 ).

${ }^{219} \mathrm{Id}$ at 80.

${ }^{205}$ Id at 78-79.

${ }^{221}$ Id at 83.

${ }^{222}$ See Part I.A.2.

${ }^{23}$ See Petracca, Rotation in Office, in Benjamin and Malbin, eds, Limiting Legislative Terms at 35-38 (cited in note 10); Fund, Term Limitation, in Benjamin and Malbin, eds, Limiting Legislative Terms at 237 (cited in note 184); Tabarrok, Term Limits and Political Conflict, in Grofman, ed, Legislative Term Limits at 243-44 n 7 (cited in note 150). Another reason for lower congressional tenure in the past may have been that lower technology increased travel costs and made keeping in touch with a district more difficult. In addition, the capital city only recently became a pleasant place to live, see Will, Restoration at 11-12 (cited in note 10 ), and until the 1930s, congressional sessions lasted two to
} 
out the nineteenth century, congressional turnover was typically 40 to 50 percent per term. ${ }^{24}$ Even Abraham Lincoln left after one term in Congress under informal rotation norms. ${ }^{225}$

Likewise, the larger the total amount of distributable governmental benefits per district, the larger the penalty for not having a senior representative and the greater the ideological slack. ${ }^{26}$ States or nations with large amounts of total distributable governmental benefits thus have greater incentives to favor term limits to reduce such ideological slack. Such political jurisdictions would also benefit more from any pork reduction produced by an overall decrease in seniority. Accordingly, since the smaller size of government made distributable benefits far less significant in the late $1700 \mathrm{~s}$, the collective action problem motivating term limits was likewise far less pressing during the constitutional framing than it is now. ${ }^{227}$

Indeed, long tenure and high pork levels are mutually reinforcing. Elevated pork levels are likely to increase average tenure by imposing a greater penalty on incumbent replacement. Longer average tenure increases the amount of pork produced. This suggests the pressure for term limits in the United States will continue to grow, not abate, in the future.

The enthusiasm for term limits will also be higher the greater the value that voters put on ideological fit. ${ }^{228}$ Term limits should thus be more popular in more ideologically contentious times. This helps explain the sudden popularity of term limits in 1990 on the heels of the end of a Cold War period that tended to submerge domestic ideological conflict. To the extent voters believe decreasing average legislative tenure will lower the level of nonpork distributable governmental benefits, term limits will also be more popular the more conservative voters are in their beliefs about the proportion of nonpork that is socially desirable, as voters recently seem to have become.

\footnotetext{
three months, requiring the legislator to return to some other line of work, see Fund, Term Limitation, in Benjamin and Malbin, eds, Limiting Legislative Terms at 228 (cited in note 184). In state legislatures, past high turnover has been attributed to lower pay, smaller staffs, and shorter sessions, all of which were purposefully changed in reforms beginning in the 1960s that by the 1980s produced the low turnover that inspired term limits. See Everson, Impact of Term Limitations, in Benjamin and Malbin, eds, Limiting Legislative Terms at 191-94 (cited in note 209).

${ }^{224}$ Kesler, Bad Housekeeping, in Bernard and Malbin, eds, Limiting Legislative Terms at 244 (cited in note 196).

mas Id.

2ss See also Appendix.

${ }^{2 \pi}$ See also Part I.A.2.

${ }^{2 a}$ See also Appendix.
} 
It bears emphasis that the collective action problems described above apply only for political jurisdictions that elect legislators by district. Not every nation elects legislators in this fashion. For example, to the extent a nation uses a system of proportional representation where legislators are chosen from a party list, then the effects of relative seniority do not coerce voters to retain senior incumbents. One would thus expect that term limits would be less popular in such nations. ${ }^{229}$ Likewise, if a city elects all its commissioners at-large through a citywide vote rather than by precinct, then the city is less likely to favor term limits. ${ }^{230}$

In addition, the collective action problems require that seniority confer extra legislative clout making it especially difficult for districts to give up senior representatives. In parliamentary systems like Britain's, where senior representatives may be relegated to the back bench and junior representatives elevated to the government, the connection between seniority and clout is less reliable. One would thus expect term limits to be less popular in such parliamentary systems than in systems that separate the executive and legislative powers.

\section{The Collective Action Problem of State Limits on Federal Officials}

The analysis so far provides an explanation for why a state might pass term limits on state legislators, or why the entire nation might (through constitutional amendment or, if permissible, federal statute) pass term limits on federal legislators. In those instances the collective action is taken at the level of the collectivity affected by the legislature, so that the voters have incentives to weigh the full benefits and costs of term limits. But why do state voters ever pass term limits on their state's representatives to Congress? After all, an individual state deciding whether to limit the terms of its U.S. Senators seems subject to similar collective action problems as a state deciding whether to vote out of office a particular senior senator. ${ }^{231}$ That is, if a particular

\footnotetext{
${ }^{22}$ However, sometimes parties in a proportional representation government can organize themselves to provide pork by dividing jurisdictions into subunits, each of which is assigned a deputy to provide particularized benefits. See Carey, Term Limits in Costa Rica, in Grofman, ed, Legislative Term Limits at 328-31 (cited in note 132) (finding that Costa Rican parties organize in this fashion). In such a country, term limits might be attractive to reduce pork levels, and have in fact been used in Costa Rica.

${ }^{200}$ The entry barriers described in Part III may, however, provide sufficient grounds for term limits even in such cities.

${ }^{231}$ A state deciding whether to reelect a senior member of the House of Representatives is subject to somewhat greater collective action problems because the smaller size of
} 
state passes term limits that oust its federal officials, it lessens its seniority and share of legislative power whether or not the other states have enacted term limits on their federal officials. Whatever collective action problems pressure them to reelect senior Senators thus seem likely to also pressure them to nix term limits that would oust those same Senators.

This explains why state-enacted term limits never take the form of retroactive limits that would immediately oust senior federal officials. Rather, all twenty-four of them have been prospective limits on the future number of years those legislators can serve. If, for example, a legislator has already served eighteen years, he can serve another twelve under a prospective twelve-year term limit. Voters know the difference. The only legislative term limits proposals ever defeated by voters-in Washington in 1991 and Utah in 1994-were also the only ones that would have applied retroactively. ${ }^{232}$ And those measures lost because of fear that the relative legislative clout of the state's congressional delegation would suffer from retroactive limits. Term limits opponents made such arguments the central focus of their opposition, stressing that the state would lose seniority and leadership positions in Congress, including the Speaker of the House, and thus be committing "unilateral disarmament" by lessening the state's legislative clout on federal issues of particular interest to the state. ${ }^{233}$ In Washington, where the most detailed polling

districts (1) makes the ratio of distributable benefits to costs incurred in the jurisdiction larger, (2) means a larger share of any distributable benefit reduction must be shared with other jurisdictions whether they cooperate or not, and (3) makes any informal cooperation even less feasible because 435 rather than just 50 regions would have to coordinate. Still, a state deciding whether to adopt term limits for its congressional delegation faces a collective action problem similar in kind (though less in degree) to that it faces in deciding whether to reelect them.

${ }^{2} 2$ In thirty-four opportunities, voters have rejected term limits only three times: once each in Washington, Utah, and Mississippi. See Bill Hord, Outside Cash Backed Term Limits Effort, Omaha World Herald 9SF (Sept 16, 1996). The rejected Washington and Utah initiatives were retroactive, id, and the Utah vote also reflected the fact that Utah already had a prospective term limits law with a trigger clause. See notes 238,243 . The Mississippi rejection came after the Supreme Court invalidated the limits on federal officials, and did not involve a pure legislative term limits proposal because the initiative would also have limited the terms of local officials such as sheriffs who do not have reelections that pose collective action problems. This extension to such local officials generated much of the opposition to the Mississippi initiative. See Reed Branson, Term Limits Backers Vow Narrower Effort, The Commercial Appeal B2 (Nov 9, 1995); Editorial, Scaring Mississippi Voters, Wall St J A18 (Oct 30, 1995). See also Part II.C.2 (noting that the collective action problems arise only for elections to represent districts within a larger political entity). All three votes are thus consistent with the collective action explanation put forth here. Note that the political entry barrier problem discussed in Part III could not alone explain prospectivity since states would have incentives to reduce entry barriers as soon as possible.

${ }^{{ }^{*}}$ Olson, Term Limits Fail, in Benjamin and Malbin, eds, Limiting Legislative Terms 
data were collected, polls before the election showed that large percentages of potential supporters of term limits could be dissuaded by the clout argument. ${ }^{234}$ And polls conducted after the defeat of retroactive term limits showed that 52 percent of the "no" votes were cast because of one version or other of the relative clout argument. ${ }^{235}$ Fifteen percent of those voting "no" said they would have voted differently if the term limits were imposed nationwide. ${ }^{236}$ When presented with a proposal for prospective term limits in 1992, Washington voters accepted them. ${ }^{237}$ And in Utah, the voter rejection reflected the fact that Utah already had adopted prospective term limits. ${ }^{238}$

Of course, prospective term limits imposed by a state on its officials are not the same as term limits imposed nationwide. But such prospective term limits have been enacted as part of simultaneous term limits movements in many other states.. ${ }^{239}$ Stateimposed term limits can thus be seen as an offer by the enacting states to cooperate in removing long-term incumbents only if other states do the same. If other states do not respond by passing similar limits, the original "offer" can be withdrawn by repealing the term limits in those states that first enacted them.

The prospect of such repeal is not an academic fantasy. It was explicitly contemplated by term limits advocates. ${ }^{240}$ And

at 79-82, 92-93 (cited in note 5); Will, Restoration at 222 (cited in note 10); Tony Semerad, Rivals Battling Over Ballot Measures, Salt Lake Trib B1 (Nov 6, 1994); Dan Harrie, Term Limits Draw Fresh Opposition, Salt Lake Trib B1 (Oct 19, 1994); Editorial-Commentary, Utah Has Term Limits Now, Salt Lake Trib A30 (Sept 2, 1994). Washington state was particularly interested in federal issues since the federal government owned 29 percent of its land and had strong control over its water and electricity. Olson, Term Limits Fail, in Benjamin and Malbin, eds, Limiting Legislative Terms at 79-82, 92-93 (cited in note 5).

${ }_{z a}$ Olson, Term Limits Fail, in Benjamin and Malbin, eds, Limiting Legislative Terms at 83 (cited in note 5 ).

${ }^{235}$ Id at 85 (21 percent cited lost clout of state, 19 percent that state would be doing so alone, 8 percent losing Speaker of House, and 4 percent losing influence on various issues affected by clout).

${ }^{256}$ See Will, Restoration at 222-23 (cited in note 10).

${ }^{237}$ Brief for the State Petitioner, US Term Limits (Nos 93-1456, 93-1828), 1994 WL 444683 at *3 (cited in note 10 ).

${ }^{23}$ See Tony Semerad, Term Limits Aren't Dead Utah Demos, Salt Lake Trib A1 (Nov 10, 1994). Also consistent with the collective action explanation, the existing term limits law contains a trigger clause. Id. See also note 243 and accompanying text.

${ }^{230}$ Term limits activists themselves recognized that they exacerbated collective action concerns about losing relative legislative clout in their 1991 loss because Washington was the only state voting on the issue that year. Stuart Rothenberg, Transplanting Term Limits: Political Mobilization and Grass-Roots Politics, in Benjamin and Malbin, eds, Limiting Legislative Terms 97, 110 (cited in note 5). They put term limits initiatives on the ballot in fourteen states in 1992, all of which then won passage, including in Washington. See Boeckelman and Corell, Analysis of Term Limitation Elections, in Grofman, ed, Legislative Term Limits at 185 (cited in note 187).

${ }^{240}$ Rothenberg, Transplanting Term Limits, in Benjamin and Malbin, eds, Limiting 
there was related precedent for it: in 1790, Pennsylvania was forced to repeal its term limit on its federal representatives before it took effect in the new Congress when no other state followed suit under the new federal Constitution. ${ }^{241}$ More recently, when a majority of states failed to follow its lead in enacting federal term limits by 1995 , Colorado reacted by delaying the start date for counting prospective term limits from 1991 to $1995 .^{242}$ The identity of the state is telling. Colorado was the first state to face the possible loss of clout because, of the three states that had enacted term limits in 1990, it was the only one to impose them on its congressional delegation. The issue has since become moot for state-enacted term limits since US Term Limits invalidated their application to Congress.

As the term limits movement became more regularized, states even started to include explicit "trigger clauses," making term limits on federal legislators effective only after a certain number of other states also imposed such limits. ${ }^{243}$ This was a direct recognition of the root collective action problem. Indeed, one of the states was Washington, where clout arguments torpedoed the first attempt. Another of the states with a triggering clause was Utah, and voters rejected an initiative that would have dropped this trigger clause in large part because of opponent arguments that such unconditional term limits would cost the state clout in Congress. ${ }^{244}$ Likewise, in Missouri, the triggering provision was responsive to criticism (from a former term limit supporter) that unilaterally limiting the terms of Missouri's congressional delegation would lose the state legislative clout in Congress. ${ }^{245}$

In contrast, a state that ousts its senior federal legislator through ordinary voting cannot regain his seniority by bringing

Legislative Terms at 110 (cited in note 239), quoting one advocate as stating in 1991: "Without retroactivity, states will have six or eight years to look at the issue. They will be able to repeal limits before they go into effect if other states don't also adopt them."

${ }^{21}$ See text accompanying note 48 . Pennsylvania had had the term limits since 1776 , see id, but they had not presented a collective action problem under the Articles of Confederation because those mandated rotation for all states. See note 46 .

${ }^{2 *}$ See Colo Const, Art XVIII, $\$ 9$.

${ }^{2 * 3}$ See Alaska Stat $\$ 15.30 .180$ (a) (1995) (twenty-four other states); Mo Const, Art III, $\S 45$ (a), cl 1 (one-half of the states); NH Rev Stat Ann $\S$ 653:3-4 (1996), suspended by NH Legis ch 108:6 (1995) until twenty-four other states enact term limits; Utah Code Ann $\$$ 20A-10-301 (1995) (Term limit will take effect when at least twenty-four states have established legislative term limits. Utah Legis ch 264 § 4 (1994)); Wash Rev Code Ann § 29.68.015-16 (Term limit will take effect when nine other states have passed term limits. Wash Laws ch 1 (1991) (Initiative Measure No 573)).

${ }^{24}$ See Semerad, Salt Lake Trib at B1 (cited in note 233); Editorial-Commentary, Salt Lake Trib at A30 (cited in note 233).

${ }^{2 \pi}$ See Calamita, Comment, $8 \mathrm{~J} \mathrm{~L} \mathrm{\&} \mathrm{Pol} \mathrm{at} 593$ n 184 (cited in note 9). 
him back if the other states fail to oust their senior legislators, and it would in any event lose the value of his seniority in the interim before the next election. States trying to coordinate through ordinary voting would also have a much shorter time frame to coordinate the mutual ousters. This was one of the problems with the rotation provision Pennsylvania was forced to abandon in 1790: it gave the state only two years to coordinate other states in parallel action once the federal Constitution was adopted. Because all recently enacted legislative term limits were no less than six years, they provided at least a six-year period to secure similar limits in other states. In keeping with this time frame, all twenty-four state-enacted legislative term limits were passed in the 1990-95 period. ${ }^{246}$

All states might eventually hope to benefit from such stateby-state passage of congressional term limits. But it follows from this analysis that no state is uniquely interested in the passage of congressional term limits in its state; the matter is one of collective national interest. ${ }^{247} \mathrm{We}$ should thus expect to see that support for term limits would be more likely to come from national groups, while support for the opposition is more likely to come from local groups worried about losing their clout. And that is in fact what we see. ${ }^{248}$

Granted, such parallel state-enacted term limits are an imperfect solution to the underlying collective action problem, requiring cumbersome coordination among many states, each of which has incentives to cheat by rescinding its term limits to gain a legislative advantage over other states. Nonetheless, it was rationally viewed as the only feasible means open. The alternative of a federal statute mandating term limits not only required the approval of federal legislators with a self-interest in opposing such limits but also was foreclosed by dicta in Powell. ${ }^{249}$ And constitutional amendment procedures both imposed onerous supermajority obstacles and gave that same self-interested fed-

\footnotetext{
${ }^{246}$ See note 6.

${ }^{227}$ After all, enacting term limits is a matter of social contracting around a collective action problem, and all parties to a contract have an incentive to make it happen; indeed, it can be expected that each party will be more attentive to defining the duties of the other than his own.

${ }^{245}$ See Olson, Term Limits Fail, in Benjamin and Malbin, eds, Limiting Legislative Terms at 86-87 (cited in note 5) (96 percent of funding for 1991 term limits campaign in Washington came from out of state compared to 52 percent of opposition funding); Rothenberg, Transplanting Term Limits, in Benjamin and Malbin, eds, Limiting Legislative Terms at 97-101 (cited in note 239) (describing national term limits groups); Hord, Omaha World Herald at 9SF (cited in note 232).

${ }^{249}$ See Part I.A.5.
} 
eral legislature an effective veto on the proposed change. ${ }^{250}$ That voters were willing to try the difficult route of state-enacted term limits is a testament to the infeasibility of the alternatives and to just how great voter frustration with legislative entrenchment had become.

In addition, the states that enacted term limits on their federal officials may well have hoped to change the incentives of the federal legislature. If states with majority representation in Congress had enacted federal term limits, and the remaining states failed to follow suit, then a congressional majority would have found itself relatively disfavored by a system that rewarded seniority. That legislative majority would thus have had strong incentives to abolish any internal legislative rules that accentuated the advantages of seniority. ${ }^{251}$ Such a rule change alone would have lessened ideological divergence. This helps explain why some states chose to trigger their congressional term limits upon adoption by a majority of states.

If congressional term limits had been enacted by states holding two-thirds of Congress, their federal legislators would have had incentives and sufficient votes to propose a national constitutional amendment mandating similar term limits on federal officials. This would have been true even if the federal legislators from term-limited states were relatively senior because they would have gained nothing from laboring under prospective term limits more onerous than legislators from other states. For example, a legislator with eighteen-years experience who could have served only twelve more years under state-imposed term limits would have lost nothing personally from voting for twelveyear constitutional term limits. Indeed, he would have improved prospects for his state in a way that would have aided his next reelection.

\footnotetext{
$\approx \approx$ See Part I.B.4.

${ }^{2 x 1}$ In fact, before the Supreme Court struck down state-imposed term limits, House of Representatives rule changes relaxed seniority advantages. Indeed, historically, a large influx of freshman legislators has produced changes to rules favoring senior legislators. In 1974, an influx of freshman Democrats resulted in the elimination or weakening of many formal seniority advantages, though the informal ones persisted. See Linda Cohen and Matthew Spitzer, Term Limits, 80 Georgetown L J 477, 508-09 n 88 (1992). In 1994, a similar influx of House Republicans gave Speaker Gingrich power to select committee chairs and members without regard to seniority. See Craig D. Margolis, House Out of Order: Committee Reform in the Modern House of Representatives, $11 \mathrm{~J} \mathrm{~L} \mathrm{\&} \mathrm{Pol} \mathrm{273,} 335$ (1995). Ultimately, these proved to be modest, see note 135 , but that is probably because without term limits even freshman legislators have an incentive to maintain a system that confers seniority advantages because it increases their odds of reelection, see text accompanying notes 134-35.
} 
What if no such action by the federal legislature had been forthcoming during the six- to twelve-year period of prospectivity provided by state-enacted congressional term limits? Then the enacting states could still have rescinded their federal term limits before they suffered any actual loss from a relative lack of seniority in their representation.

In short, state-enacted federal term limits were hardly a perfect means to a nationwide limit. But they may have been not only an attractive alternative to directly shooting for a constitutional amendment but the most likely path to obtaining such an amendment in the long run. Unfortunately, this path was blocked by the Supreme Court's decision in US Term Limits.

To be sure, there are alternative possible strategies. Activists have, for example, petitioned for initiatives instructing a state's representatives in Congress to vote for a term limits amendment to the Constitution. ${ }^{252}$ A similar strategy succeeded in getting the Seventeenth Amendment enacted. But such instructions are of course not binding. And unlike with the Seventeenth Amendment, federal legislators have direct personal incentives to vote against the amendment absent any stateimposed limit on their terms. The collective action problem described above would, in any event, coerce voters for any individual district to reelect their incumbent even if she failed to follow their instruction on term limits. Nonetheless, it may be the best remaining strategy after US Term Limits.

\section{POLITICAL ENTRY BARRIERS}

\section{A. Incumbency as an Entry Barrier}

Entry barriers can be high in politics because incumbents have the considerable advantage of name recognition. To some extent, this brandname advantage results from legal favoritism. Federal law helps incumbents build brandname by giving them franking privileges, large staffs, and recording studios. ${ }^{253}$ It also sets spending and contribution limits that make it hard for challengers to overcome their disadvantage in name recognition. ${ }^{254}$

\footnotetext{
${ }_{252}$ See Paul Jacob, Memorandum to Term Limit Activists (Jan 18, 1996). See also Sheffner, Roll Call at 6 (cited in note 107).

${ }^{23}$ US Term Limits, $115 \mathrm{~S}$ Ct at 1911 (Thomas dissenting) (citation omitted).

${ }^{254} \mathrm{Id}$ at 1912 (citation omitted). Because of Supreme Court decisions invalidating mandatory spending limits, currently spending limits only apply to candidates who agree to them in exchange for federal funds. See Fred Wertheimer and Susan Weiss Manes, Campaign Finance Reform: A Key to Restoring the Health of Our Democracy, 94 Colum L Rev 1126, 1131 (1994). Since public financing has not yet been extended to Congress, this currently means the limits effectively apply only to the President.
} 
But even without such legal advantages, the office inevitably gives an edge. During their tenure, incumbents will have had opportunities to speak to Rotary clubs, preside over school-opening ceremonies, and meet likely contributors. Their tenure in office also allows them to build support by performing casework for constituents and to put themselves and their positions in the news by giving speeches in Congress, issuing statements, holding press conferences, or appearing on talk radio or television programs. ${ }^{255}$

The result is that incumbency "is the most important determinant of congressional election outcomes."256 The longer the incumbent serves, the longer she can use such advantages to improve her name recognition and reputation. Entry barriers should thus be higher the longer the incumbent's tenure. This is consistent with empirical studies (discussed above) that estimate the incumbency advantage at 10 to 12 percent of the vote, and show ideological divergence increasing with tenure. ${ }^{257}$ It is also consistent with the astonishingly high reelection rates recounted above. ${ }^{258}$

But perhaps more specific evidence of entry barriers is the relative paucity of serious challengers. Of the House members seeking reelection in 1990, 19.5 percent had no major party challenger at all. ${ }^{259}$ An additional 38.9 percent had party challengers who could not even raise more than $\$ 25,000$ to challenge the incumbent. ${ }^{260}$ And 32.5 percent had challengers who had raised more than $\$ 25,000$ but less than half what the incumbent had raised. ${ }^{261}$ The result was that only 9.1 percent of the incumbents running faced entry by what we might generously call serious challengers: those able to raise at least half what the incumbent raised. Not surprisingly, 96 percent of the incumbents running won reelection. ${ }^{262}$

${ }^{255}$ See generally David R. Mayhew, Congress: The Electoral Connection 49-73 (Yale 1974) (Legislators' desire to maximize reelection leads them to three main activities: advertising, providing particularized benefits like pork and casework, and position-taking.).

${ }^{255}$ Paul S. Herrnson, Congressional Elections 205 (CQ 1995).

${ }^{\star 2}$ See Part II.B.2.

${ }^{2 * x}$ See Part II.C.2.

${ }^{23}$ See Wertheimer and Manes, 94 Colum L Rev at 1134-35 (cited in note 254).

${ }^{25}$ Id.

$\infty 1$ Id.

${ }^{252}$ Id. In 1992, the statistics were only slightly less alarming. Only 20 percent of challengers could raise at least half of what incumbents raised, and 93 percent of running incumbents won reelection. See id. 


\section{B. Why Entry Barriers Matter}

In economic markets, we can distinguish two reasons why entry barriers are deemed potentially harmful. First, barriers might preclude the entry of an additional firm that would make a noncompetitive market more competitive. This improves the performance of a noncompetitive market by increasing output and lowering prices even if the new entrant is no more efficient than existing firms. Second, barriers might prevent entry by firms more efficient than those currently in the market. This improves market performance even if the current market has many competitors and even if the new entrant replaces an existing firm and thus produces no net increase in the number of firms in the market.

1. More competition even if less desirable than incumbent.

The first reason might seem inapplicable to political markets. Unlike in product markets, only one representative can serve the district at a time. Thus, competition for political office might seem much like competition for a monopoly position in a natural monopoly. We want to make sure we end up with the most efficient monopolist, but we cannot ultimately have more than one firm in the market.

However, having more candidates running might help present a broader and better defined set of views and issues in any election. For example, Ross Perot's presidential campaign in 1992 arguably forced Clinton and Bush to address the deficit more than they otherwise would have. This could improve the operation of the political market even if only one candidate can win in the end. If so, then an incumbent's brandname advantage may be undesirable (because it deters entry) even though voters prefer (and thus vote for) the brandname incumbent in actual elections. Thus, like the collective action problem, this is not a problem redressable through ordinary voting.

Moreover, even if less desirable than the incumbent, a challenger excluded by entry barriers might be more desirable than the challengers now running. Suppose $\phi$ represents the degree of fit between the public positions a candidate is willing to take and his electorate's views, and $\phi$ (incumbent) $>\phi$ (excluded challenger) $>\phi$ (present challenger). An incumbent who privately favors policies that would, if he pursued them, produce a $\phi$ lower than any of these can, because of entry barriers, adopt a public position as low as $\phi$ present 
challenger). ${ }^{263}$ If the entry barriers were eliminated or the incumbent barred from reelection, the public position of the ultimately elected official would have a $\phi$ at least as high as $\phi$ (excluded challenger). For example, even if Bob Dole would have won the 1996 Republican nomination regardless of whether or not Colin Powell had run, an entry by Powell likely would have produced a shift in Dole's positions.

Such a shift in position can produce more satisfactory representation for an electorate even if, with the brandname advantage, the incumbent not only won all elections against existing challengers, but would have won against the excluded challenger as well. Thus, again, this rationale for term limits is not susceptible to the paradox of being remediable by ordinary voting.

\section{More desirable than incumbent.}

The second reason for condemning entry barriers has been questioned in economic markets. ${ }^{264} \mathrm{~A}$ more efficient potential entrant, the argument goes, should always be able to contract with a less efficient existing firm to overcome the entry barrier. A more efficient potential taxicab owner should, for example, be able to buy a medallion from an existing cab owner at a price profitable to both. Or a more efficient firm can buy an established brandname from an existing firm. Of course, often legal restrictions on transfer exist. Not all licenses can be sold. And the purchase of an existing company or brandname by a potential entrant can violate antitrust law if without it independent entry would have occurred. But where such restrictions do not exist, the objection is valid: because holding a transferable market advantage involves the opportunity cost of foregoing its possible sale price, the existing firm suffers no larger costs than a potential entrant. Thus, the entry barrier would not prevent a more efficient entrant from switching places with a less efficient existing firm.

But political brandnames cannot be sold in this fashion. ${ }^{265}$ Incumbents can create an effective political brandname by developing popularity for the views and reputation associated with their name through advertising and position-taking. But an in-

\footnotetext{
${ }^{2 \times 3}$ With the collective action problems identified in Part II, he could of course adopt an even lower $\phi$. But the argument here follows even if no such collective action problems exist, as in the election for a single executive to govern a political jurisdiction.

${ }^{*}$ See Harold Demsetz, Barriers To Entry, 72 Am Econ Rev 47, 49-52 (1982).

$\therefore$ See John R. Lott, Jr., The Effect of Nontransferable Property Rights on the Efficiency of Political Markets: Some Evidence, $32 \mathrm{~J}$ Pub Econ 231, 232 (1987); John R. Lott, Jr., Brandnames and barriers to entry in political markets, 51 Pub Choice 87, 88 (1986).
} 
cumbent cannot transfer his name and reputation to others. The closest thing to such a transfer is when a spouse runs to fill the seat of a deceased representative, and it is interesting to note that election yields for them are far higher than for most new candidates. ${ }^{266}$ But that is an involuntary transfer. The closest thing to a voluntary transfer is endorsing others, and "there is a huge difference between being endorsed by Ronald Reagan for the Presidency and running as Ronald Reagan."267

Moreover, even if a politician could transfer his reputation, a political entrant could not easily transfer the funds to buy it. A successful entrant in business markets can anticipate making money from sales to consumers, the capitalized value of which he can pay to an incumbent firm for its brandname. In contrast, the "proceeds" of a successful political entrant are mainly not money but rather votes and political support, which cannot be monetized and transferred to the incumbent. Even if a political entrant does raise support in the form of monetary campaign contributions, he cannot legally spend that to pay an incumbent to resign his office. Such payments are impermissible for a very good reason: we would hardly want offices or political reputations auctioned off to the highest monetary bidder. That would only exacerbate rent-seeking behavior and the advantage of interest groups better positioned to raise funds. What we want is for the office to go to the candidate who can offer the highest political support. But political support does not come in a form that can be exchanged to an incumbent for his brandname advantage.

Because of these obstacles to transferability, the incumbent will run for reelection rather than sell his brandname to a lessknown challenger who would do a better job. Nontransferability can accordingly make brandname advantage an entry barrier that prevents a more desirable challenger from winning an election.

Still, one might justifiably question whether such a political brandname advantage is undesirable on balance. ${ }^{268}$ Voters and

\footnotetext{
${ }^{256}$ The second closest analog is when children of politicians run for office. Interestingly, politicians' children enter politics at higher than average frequency, but the vast majority do not run at all. Lott, $32 \mathrm{~J}$ Pub Econ at 232 (cited in note 265). This is consistent with the proposition that political brandname is difficult to transfer to anyone, including children, but is even more difficult to transfer to persons outside the family.

${ }^{20}$ See Lott and Davis, 74 Pub Choice at 475 (cited in note 154).

${ }^{2 x}$ See, for example, Tabarrok, 14 Cato $J$ at 343-44 (cited in note 12). Lott's brandname model does not answer this question because (1) it simply assumes the brandname increases the chances of reelection without benefiting the voters; and (2) it only addresses the possibility of a more efficient challenger being excluded. Lott, 51 Pub Choice at 88-89 (cited in note 265).
} 
consumers who choose an established brandname over lessknown competitors must do so because they feel that on average it makes them better off. The less-known competitor might be much better at delivering desirable governmental services, but he might be much worse. Given the expected outcome and relative risks of choosing one or the other, they prefer the brandname. Thus, people stop at McDonald's because it offers the assurance of a certain quality and price even though they might get a better quality/price mix at an unknown restaurant they passed on the way. If McDonald's were unable to sell its brandname to a more efficient franchiser, it would hardly seem desirable to adopt the equivalent of term limits, prohibiting McDonald's from using its brandname for longer than twelve years. The squelching of the brandname would deprive the market of information that makes consumers better off on balance. ${ }^{269}$ If they weren't better off, they would choose (vote for) the unknown competitor over the brandname. ${ }^{270}$

The problem, however, is that voters may never have a choice between the more desirable challenger and the brandname incumbent. Such political challengers may never even enter the race because they conclude that the costs of creating their own brandname are too high given other uses of their time and resources. In economic markets, entrants can more easily recoup such costs with increased sales and should thus make the necessary brandname investment if it is efficient to do so. But in political markets, brandname investments often confer uncompensated positive externalities or are compensated with votes and political support that do not cover the necessary monetary investment. Moreover, political challengers know that the incumbent can respond to any investment they make in a rival brandname with increased investments in the incumbent's own brandname. Accordingly, entry barriers may mean that actual elections present voters with a choice between brandname incumbents and less desirable unknown challengers. Voters' failure to vote for unknown challengers over brandname incumbents in actual elections does not mean they could not get more desirable candidates, and better representation, if the incumbent's brandname advantage were reduced or eliminated.

\footnotetext{
${ }^{*}$ Compare Demsetz, $72 \mathrm{Am}$ Econ Rev at 50 (cited in note 264) (makes no sense to talk of entry barriers when the barrier is really caused by information costs that are a cost of production that each firm faces equally).

"See Daniel Friedman and Donald Wittman, Term Limits as Political Redistribution, in Grofman, ed, Legislative Term Limits 229, 229-30 (cited in note 5) (relying on such logic to dismiss brandname entry barrier argument for term limits).
} 


\section{Term Limits to Lower Entry Barriers}

Term limits are one solution to this entry barrier problem. By preventing long-term incumbents from running for office, they lessen the possible brandname advantage and thus lower the height of political entry barriers. Some brandname advantage may persist. Term-limited legislators can use their brandname to seek other political offices or, under rotation versions of term limits, can even seek the same office after waiting some six to twelve years. But political fame fades quickly over time and across political boundaries. How many of us know the names of representatives who served twelve years ago or in other districts? Moreover, a reputation will often be for serving a particular generation or district and thus not work in other times and places. ${ }^{271}$ Term limits will thus lower entry barriers.

To the extent fame does carry over in different regions, such fame will not be unique and no incumbent will enjoy a safe seat. Indeed, one of the great advantages of term limits is that they produce real competition between famous term-limited officials for other political posts. Currently, normal risk aversion gives prominent politicians incentives to stay in their secure offices and bide their time until another seat becomes vacant by resignation or retirement, which is what the evidence shows they do. ${ }^{272}$ By ousting them from such safe sinecures, term limits encourage well known politicians to compete with each other more often. ${ }^{273}$

\footnotetext{
${ }^{2 n}$ In the nation (Costa Rica) with the longest history of legislative term limits, only 13 percent of term-limited legislators have come back to serve another term. See Carey, Term Limits in Costa Rica, in Grofman, ed, Legislative Term Limits at 323 (cited in note 132).

${ }^{m 2}$ See Peverill Squire, Challengers in U.S. Senate Elections, 14 Legis Stud Q 531, 532 (1989) (Senate challenges); Gary C. Jacobson and Samuel Kernell, Strategy and Choice in Congressional Elections 32 (Yale 1981) (House challenges); Gary W. Copeland, Term Limitations and Political Careers in Oklahoma: In, Out, $U_{p}$, or Down, in Benjamin and Malbin, eds, Limiting Legislative Terms 139, 147-48 (cited in note 5). This rebuts an objection sometimes made to term limits: that they will cause challengers to defer running until the incumbent's term limit comes up. See Fowler, Comment on Competition, in Benjamin and Malbin, eds, Legislative Term Limits at 183-84 (cited in note 12); Hibbing, Careerism in Congress, in Dodd and Oppenheimer, eds, Congress Reconsidered at 69 (cited in note 151); Bernard Grofman and Neil Sutherland, The Effect of Term Limits When Competition is Endogenized: A Preliminary Model, in Grofman, ed, Legislative Term Limits 175, 175 (cited in note 5). Although this may sometimes happen, any dampening of entry would surely be less than that which occurs without term limits when challengers wait for incumbents to come of retirement age. And the politicians ousted in one office by term limits cannot defer challenges to other incumbents unless they are willing to be out of office (and away from its fame-producing advantages) for a significant period.

${ }^{73}$ See K. Alexander, The Great.Money Chase (Common Cause April 1995) (of twentyseven California legislators deciding not to run for reelection in 1994 given the prospect of
} 
By reducing the costs of entry for newcomers, lower entry barriers should also produce additional entry more generally. True, in some sense, higher entry barriers also encourage entry by increasing the benefits of successful entry. For example, being a monopolist who enjoys the advantage of entry barriers is so attractive that we might expect more firms to try for it. ${ }^{274}$ Likewise, the prospect of a thirty-year legislative career may be more attractive than a twelve-year-term-limited career and thus increase the benefits of political entry. Such logic has persuaded others that term limits discourage entry. ${ }^{275}$ But the net effect of reducing entry barriers should still be additional entry for no less than six reasons.

First, some realism. With only 9.1 percent of congressional incumbents facing serious challengers in $1990,{ }^{276}$ current levels of political entry are extraordinarily low. Such low levels make it implausible that incentives without term limits are doing much to encourage entry. And they make it hard to believe things could get any worse with term limits.

Second, I doubt many people running for political office would be deterred by a law limiting them to twelve years in office. The average tenure of sitting congresspersons was 11.14 years in $1994 .{ }^{277}$ While this underestimates matters by including members who have not yet completed their service, efforts to adjust for this using 1977-91 continuation rates produce a predicted mean completed tenure of 13.5 years in the House. ${ }^{278}$ This does not offer much more inducement than the maximum career available under a twelve-year term limit, though of course the average tenure under term limits would be less. ${ }^{279}$ The disincen-

having their term limited in 1996, twenty-two ran for other elective offices, often against other incumbents); Bernard Grofman, Introduction, in Grofman, ed, Legislative Term Limits at $16 \mathrm{n} 21$ (cited in note 5) (of twenty-two California Assembly members retiring under the specter of term limits, eighteen ran for other offices).

"2" Such rent-seeking behavior is in fact generally understood to be inefficient. The cost of competing to become a monopolist increases the deadweight loss of monopoly by eating up even the monopolist's surplus. See Richard A. Posner, The Social Costs of Monopoly and Regulation, in James M. Buchanan, Robert D. Tollison, and Gordon Tullock, eds, Toward a Theory of the Rent-Seeking Society 71 (Texas A\&M 1980).

${ }^{r 3}$ See Fowler, Comment on Competition, in Benjamin and Malbin, eds, Limiting Legislative Terms at 182,184 (cited in note 12).

${ }^{26}$ See text accompanying notes 259-62.

${ }^{27}$ See Elizabeth Garrett, Term Limitations and the Myth of the Citizen-Legislator (preliminary draft 1996) 17 \& n 33 (on file with U Chi L Rev).

${ }^{2 \pi}$ See W. Robert Reed and D. Eric Schansberg, An Analysis of the Impact of Congressional Term Limits, 32 Econ Inq 79, 82 (1994).

${ }^{2 \pi}$ One estimate, assuming that reelection rates are unaltered by term limits, is that average completed tenure would decline to 6.3 years. Id. That should be even lower if reelection rates go down. But that brings us to the third, more important, point in the 
tive is even less for state legislators because even without term limits only 24 percent serve more than twelve years. ${ }^{280}$

Third, and more important, a lower mean completed tenure overstates the deterrent to entry because it measures the expected tenure of an incumbent. But the expected years in office from being a challenger are what matters in evaluating the attraction of entry. ${ }^{281}$ And since over 90 percent of challengers currently lose, that expected value is currently less than two years. Thus, even a six-year term limit may not matter much to newcomers. What matters far more is the probability of winning, and that should go up with term limits either because more seats will be open or because the less senior incumbents will have lower brandname advantages. Thus, even if the benefits of successful entry go down under term limits, the expected benefits of entry should still go up.

Fourth, the prospect of being turned out may not matter much to candidates. It is not as if elected office pays more than the sort of private jobs term-limited politicians could get after serving in office. Of course, politicians may run to use an office as a stepping stone to higher political offices. But if so, they are likely to have to make their moves by the end of their term limits anyway. ${ }^{282}$ And term limits in those higher political offices should increase their chances to move up.

Fifth, a longer legislative career will not be more attractive to everyone. Many may only want to enter public service for a limited time before returning to private life but want to make sure they can accomplish something while they are in office. Such persons would be more attracted to an office that lasts only six to twelve years but assures them of real power by the end of that period than to an office that might last thirty years but requires them to wait decades before rising to real power. A twelve-

text.

${ }^{20}$ Combining upper and lower state houses, only 30 percent serve as long as twelve years, see Moncrief, et al, For Whom the Bell Tolls, in Grofman, ed, Legislative Term Limits at 121-23 (cited in note 209), and one-fifth of these leave without going on to a thirteenth year, id at $128 \mathrm{n}$ 5. See also Copeland, Political Careers in Oklahoma, in Benjamin and Malbin, eds, Limiting Legislative Terms at 145 (cited in note 272) (finding Oklahoma legislators unworried about term limits because few expect to serve more than twelve years).

${ }^{* 1}$ (Expected years in office from challenging) $=$ (probability of winning challenge) $*$ (expected years in office if win and become incumbent).

${ }^{\infty}$ See Copeland, Political Careers in Oklahoma, in Benjamin and Malbin, eds, Limiting Legislative Terms at 145-46 (cited in note 272) (noting that twelve-year limit unlikely to affect Oklahoma politicians with progressive ambition since there are "no recent examples of a state legislator with at least twelve years of service seeking election to the U.S. Congress or to another statewide office"). 
year term limit, for example, would reduce the time necessary to rank in the 80th percentile of seniority (where positions like committee chairs normally go) from sixteen to twenty-two years, to six to eight years. ${ }^{283}$ Indeed, this may result in a net increase in the value of holding office even for those solely interested in wielding the maximum political power. ${ }^{284}$

More fundamentally, even if term limits did reduce the benefits of entry, this would at most be a feedback effect that could not offset the main effect. The higher benefits of entry under the current system hold only so long as entry barrier costs actually prevent others from entering, which must mean entry costs exceed entry benefits. A legislative seat can offer a thirty-year career carrot only if in fact winning that seat precludes meaningful competition for the next thirty years. ${ }^{285}$ Such entry barriers thus cannot encourage entry more than they discourage it.

Finally, term limits should encourage entry by making the date incumbents will depart office more definite. Challengers have some incentives to run even before they believe they can win an election because such prior challenges increase their own reputation and brandname in future elections. But without term limits this is a risky strategy. The challenger cannot be sure when the incumbent will depart, and if the incumbent stays a long time any past reputational investment by a challenger will have depreciated by the time the seat becomes open. ${ }^{286}$ With term limits, the challenger has more certainty that his investments will pay off in a future election once the incumbent departs.

But we need not rely solely on theory about whether lower entry costs with term limits will be offset by lower entry benefits, for some empirical evidence is available. And it supports the claim that term limits on balance encourage entry. After California imposed term limits in 1990, thus restricting the possible prospective career, candidate filings increased by 25 percent for the state senate and 50 percent for the state assembly. ${ }^{287}$ The in-

${ }^{2}$ See Reed and Schansberg, 32 Econ Inquiry at 84 (cited in note 278). In addition, the probability of attaining a leadership position would more than double under term limits, although the length of time in such positions would be less than half the time without term limits. Id at $83 \mathrm{n} 8$.

$\approx 4$ Id at 90 .

${ }^{2}$ Note also that in those once-every-thirty-years elections, candidates have an incentive to spend far more because they get a thirty-year return, which increases entry barriers for candidates with less money.

${ }^{2}$ See John R. Lott, Jr. and Kermit Daniel, Term Limits and Electoral Competitiveness 6 (forthcoming Pub Choice, Jan 1997).

${ }^{207}$ See Dan Greenberg, Term Limits: The Only Way to Clean Up Congress, Heritage Foundation Backgrounder 1, 8 (Aug 10, 1994). See Lott and Daniel, Term Limits at 15 (cited in note 286) (finding that major party candidacies increased by 24 percent of a 
crease should be even greater once the term limits start turning out incumbents this year.

Pursuant to the reasoning above, additional entry should improve the political market in three separate ways: by helping refine issues, by producing more satisfactory position-taking by representatives, or by allowing entry by representatives who can do a better job. Consistent with these predictions, after the adoption of term limits in California, vote margins decreased by 10-22 percent of a standard deviation and the probability of an incumbent being defeated increased by 14-37 percent. ${ }^{288}$ The new entrants must expend time and resources to develop a new brandname conveying their views. But they will no longer be discouraged from doing so by the large brandname advantages enjoyed by long-term incumbents.

This rationale for term limits is stronger the larger the brandname advantages associated with an office. Given the enormous media attention focused on the President, it is hardly surprising that term limits were adopted for that federal office first. The rationale is also stronger for offices that usually mark the end of a political career, such as President, since such termlimited officeholders are less likely to take their brandname advantage to elections for other offices. Because brandname advantages rise with tenure, term limits should also be more popular the longer the tenure of incumbents. It is thus predictable that presidential term limits became an issue at the end of Roosevelt's long tenure, and that congressional term limits became an issue in the early 1990s when legislative turnover had become particularly low.

Of course, it is also true that the larger the brandname advantage, the longer incumbent tenure is likely to be. Thus, other factors (such as technological changes) may have increased incumbents' advantage, which in turn produced the long tenure. Whatever the source, the enthusiasm for term limits would rise with incumbents' advantage, and there is an "existing scholarly consensus that incumbency advantage is much larger than it once was." 289 Some find no detectable incumbency advantage until after 1950; others find that an advantage of 1-2 percent in 1900 has recently become $10-12$ percent. ${ }^{290}$

\footnotetext{
standard deviation and the number of elections with only one candidate decreased by 89 percent of a standard deviation).

${ }^{2 \times 5}$ See Lott and Daniel, Term Limits at 14-15 (cited in note 286).

${ }^{2}$ Gelman and King, 34 Am J Pol Sci at 1142, 1157-58 (cited in note 148).

${ }^{20}$ Id at 1158.
} 
To some extent, the effect of tenure on brandname barriers offsets an effect discussed in Part II.C.1. Recall that there I concluded that districts with below-average seniority should be for term limits whereas districts with above-average seniority may or may not be for term limits. Standing alone, this would have led one to predict the senior districts would be less enthusiastic about term limits. But high seniority also means the district suffers from high brandname advantages and entry barriers that will make it more enthusiastic about term limits. It is thus unclear whether on balance we should expect any correlation between seniority and support of term limits. ${ }^{291}$

Finally, some might find the entry barrier argument so persuasive that it obviates any need to rely on the collective action problems described in Part II. But the evidence is to the contrary. First, legislative reelection rates are much higher than executive reelection rates. This is hard to explain unless there is some additional factor contributing to incumbency advantages in legislative races. Second, the trend toward decreasing legislative competitiveness in the last few decades is hard to explain with entry barriers because the evidence shows that incumbent legislators are no better known now than they were then. ${ }^{292}$ This is not necessarily conclusive, because it may take a lot more investment to secure the same level of brandname recognition in districts that have grown more populated and distracted over time. But it does tend to suggest that the collective action problems unique to legislatures offer a better explanation of this trend and of the timing of the 1990-95 explosion in proposals for legislative term limits. ${ }^{293}$ In contrast, executive term limits, which rest solely on the entry barrier problem, have been more or less equally popular for the last fifty years.

\section{Alternative Entry Barrier Solutions}

1. Repealing legal incumbency advantages.

It might seem that a more tailored response to political entry barriers would be to repeal the laws giving incumbents special advantages such as franking privileges and large staffs. ${ }^{294}$ But

\footnotetext{
$*_{1}$ See text accompanying note 202 (noting that difference between senior and junior district support for term limits was only 1 to 3 percent in California).

${ }^{2}$ See Kesler, Bad Housekeeping, in Benjamin and Malbin, eds, Legislative Term Limits at 246 (cited in note 196) (discussing studies conducted by John Ferejohn).

${ }^{*}$ The term limits passed during this period were the first legislative term limits enacted in the United States since the 1700s. See Bernard Grofman, Term Limits Debate, in Grofman, ed, Legislative Term Limits at 1 (cited in note 5).

${ }^{2}$ Some state term limits initiatives have in fact included reductions in legislative
} 
there are good reasons to allow our representatives to communicate with their constituents and to have staffs. Nor would such measures eliminate the brandname advantages of incumbents, most of which are inherent in holding office. ${ }^{295}$

In any event, the states enacting term limits on federal officials may have done so in part because they lack the power to repeal federal laws giving brandname advantages to incumbents. Doing so would require a congressional rule change, federal statute, or constitutional amendment, any of which requires the approval of federal legislators ill-disposed to lessen their ability to win reelection. If federal legislators from enough states were subjected to term limits, then their incentives might have changed sufficiently for such repeals to occur, ${ }^{296}$ but the Supreme Court has now foreclosed that option.

2. Ballot access restrictions.

Another more tailored response might be not to outright prohibit incumbents from running for reelection, but to deny them the right to have their names on the ballot. Arguably, this more directly offsets incumbents' brandname advantage, while still allowing the voters to retain, with a write-in campaign, an incumbent whom they strongly prefer. Indeed, the Arkansas law struck down in US Term Limits was just such a law, as were the term limits enacted in many other states. ${ }^{297}$ Such statutes seem directly motivated by the brandname advantage problem.

Forcing the incumbent to run a write-in campaign effectively gives a name recognition advantage to challengers (their name is on the ballot) that might be thought to roughly offset that of incumbents. This should encourage entry by more challengers. But if the disadvantage of not being on the ballot is much larger than incumbents' normal brandname advantage, then such a rule would effectively prohibit incumbents who exceeded the term limit from running again, thus producing the same effects as absolute term limits. The US Term Limits majority was convinced this was true, noting that in 21,300 congressional elections only six write-in candidates had ever won. ${ }^{298}$ But the evidence was unclear because only two incumbent congressmen had ever run as write-in candidates, one of whom got 27 percent of the vote after

\footnotetext{
staff. See, for example, Polsby, Am Prospect at 40 (cited in note 5).

${ }^{205}$ See Part III.A.

${ }^{26}$ See also Part II.D.

${ }^{2 \pi}$ See US Term Limits, $115 \mathrm{~S}$ Ct at $1909 \mathrm{n} 39$ (Thomas dissenting).

${ }^{208}$ Id at 1868 n 43 (majority opinion).
} 
losing his party's primary, the other of whom won in an 83 percent landslide! ${ }^{299}$

However, even if the disadvantage of denying ballot access does roughly equal the brandname advantage of the average long-term incumbent, the effects can be perverse. A highly senior long-term incumbent will have a larger than average brandname advantage and still be able to prevail while the less senior longterm incumbents fall. But it is the highly senior incumbents who have the greatest pork-providing ability and greatest ideological slack and from whom voters in other districts most want to be rid. ${ }^{300}$ Nor do such ballot restrictions do anything to reduce the substantive collective action pressure (described in Part II) to vote for long-term incumbents with a greater share of legislative clout. And ballot access restrictions might also perversely induce incumbents to devote even more effort to building a brandname capable of overcoming the obstacle. Still, even if the highly senior incumbents retain a net brandname advantage despite the ballot access restriction, their advantage should be lower than before, and thus political entry will be higher, with all the beneficial effects identified above.

Nonetheless, such restrictions seem to run contrary to the proposition in Buckley $v$ Valeo that the government cannot restrict the speech of some to "enhance the relative voice of others. ${ }^{301}$ For the point of such a ballot restriction is not to further administrative efficiency, reduce confusion, or otherwise make it easier for voters to become informed about the candidates by limiting the ballot to candidates with serious voter support. ${ }^{302}$ Rather, the point is to deny some voters the information that the incumbent is running by restricting his ability to say so on the ballot. And the restriction is justified on just the grounds deemed impermissible in Buckley, that otherwise the relative voice of others would be too weak. Term limits thus seem preferable to ballot access restrictions.

\section{Campaign finance reform.}

Often it is suggested that the real solution is campaign finance reform. ${ }^{303}$ Buckley $v$ Valeo could be overturned to impose

${ }^{\infty}$ Id at 1910 (Thomas dissenting).

"See Part II.

: 424 US 1, 48-49 (1976)

${ }^{2}$ See Tribe, American Constitutional Law \$ 13-18 at 1097 (cited in note 37) (describing legitimate purposes of ballot regulation).

See, for example, Carole Jean Uhlaner, Alternatives to Term Limits, in Grofman, ed, Legislative Term Limits 347, 347-49 (cited in note 5). 
strict equal spending limits on candidates, or evaded by giving large advertising discounts to candidates who agreed to conform to spending limits. Public funding could be extended to legislative races and used to equalize spending between incumbents and challengers. Or both candidates could be given equal amounts of free television time to help equalize their access to voters.

At first glance, such reforms seem attractive. Incumbents get the lion's share of contributions. For example, in 1990 Political Action Committees directed 92 percent of their contributions to incumbents. ${ }^{304}$ And, as already mentioned, in 1990 only 9.1 percent of House incumbents faced a challenger who had managed to raise as much as half of what the incumbent had raised. ${ }^{305}$ Moreover, campaign finance reform may be salutary for reasons unrelated to incumbency advantages, including freeing candidates from raising money and reducing all candidates' dependence on campaign contributors.

Nonetheless, to suggest such reform as a substitute for term limits misses the point about entry barriers. Because of incumbents' brandname advantages, a winning challenger typically must spend far more than the incumbent spends. ${ }^{306}$

Any campaign finance reform that assures equal spending or equal advertising time in the election helps preserve the incumbency advantage, not eliminate it. For incumbents begin each election better known because of everything their position had given them the opportunity to do and say in the past. This is why contributors tend to back them: everyone likes to invest in the likely winner. But limiting campaign contributions would only prevent incumbents from further magnifying the brandname advantage. $^{307}$ The brandname advantage actually cannot be over-

\footnotetext{
${ }^{30}$ See Calamita, Comment, $8 \mathrm{~J} \mathrm{~L} \mathrm{\&} \mathrm{Pol} \mathrm{at} 559$ (cited in note 9). In 1992, PACs contributed ten times more to incumbents than challengers. See Wertheimer and Manes, 94 Colum $L$ Rev at 1134 (cited in note 254).

${ }^{305}$ See text accompanying notes 259-62. A full 58 percent of incumbents running faced either no challenger or one who raised less than $\$ 25,000$. Id.

${ }^{306}$ See Stephen E. Gottlieb, The Dilemma of Election Campaign Finance Reform, 18 Hofstra L Rev 213, 222 (1989) ("[V]alue of incumbency has been estimated at approximately one million dollars for a federal congressional district."). See Gary C. Jacobson, Money in Congressional Elections 33-162 (Yale 1980); Gary Jacobson, Enough Is Too Much: Money and Competition in House Elections, in Kay Schlozman, ed, Elections in America 173, 192-93 (Allen \& Unwin 1987). The 1994 elections were an exception to this general tendency, with thirty-four Republican challengers who defeated Democratic incumbents spending, on average, two-thirds what incumbents spent. See Bradley A. Smith, Faulty Assumptions and Undemocratic Consequences of Campaign Finance Reform, 105 Yale L J 1049, 1065 (1996).

${ }^{307}$ In fact, time series evidence shows that congressional tenure was flat until the mid1970s, when it began to increase suddenly, see W. Robert Reed and D. Eric Schansberg,
} 
come unless the challenger can advertise far more than the incumbent in the campaign. ${ }^{308}$

Still, to those who decry the high amounts of current campaign expenditures, and the dependence on contributors they imply, it is worth noting that campaign expenditures go down significantly under term limits. To a surprising degree. In California, average campaign expenditures fell from $\$ 309,000$ to $\$ 215,000 .^{309}$ This might seem surprising because the six-year limit was imposed in 1990 prospectively and thus ousted no one until 1996. But under such term limits, candidates starting in 1992 were no longer competing for a potentially lifetime position. The shorter expected tenure means they had incentives to spend less in either defending a seat or challenging an incumbent. As term limits kick in fully, spending should decrease further because with less senior incumbents the brandname advantage needed to be overcome with campaign advertising will decline.

\section{Conclusion.}

None of the alternatives seems a better device for reducing political entry barriers than term limits. In addition, none of them would do anything about the collective action problems described in Part II. Those problems create a substantive coercion

The behavior of congressional tenure over time: 1953-1991, 73 Pub Choice 183, 184 (1992), which roughly coincides with the implementation of the first serious round of campaign finance limitations. See Federal Election Campaign Act Amendments of 1974, Pub L No 93-443, 88 Stat 1263 (1974), codified at scattered sections of Titles 2, 18 and 26 of the United States Code and declared unconstitutional, in part, by Buckley $v$ Valeo, 424 US 1 (1976).

${ }^{3 * 0}$ To really create a level playing field, reform would have to allow challengers to spend far more than incumbents. One intriguing possibility is to make spending limits lower the higher a candidate's tenure or total expenditures in past races. See John $R$. Lott, Jr., Explaining Challengers' Campaign Expenditures: The Importance of Sunk Nontransferable Brandname, 17 Pub Fin Q 108, 115 (1989). Not surprisingly, this form of campaign finance reform has gone nowhere in legislatures and is not being pushed by reform activists. In addition to this practical problem, the proposal faces a technical and conceptual problem. The technical one is how much weight to give to tenure and past campaign expenditures. The related conceptual problem is that we cannot decide how much weight to give unless we know what goal we wish to achieve. The goal generally posited (at least implicitly) is to equalize the chances that a challenger and incumbent have of winning. But that should be our goal only if we know both are equally deserving of winning, which we have no reason to believe. Indeed, standing alone, the fact that the incumbent already won one election suggests she is more deserving of office. But recognizing that forces us into the conceptually unanswerable question of just how much of incumbents' electoral advantage is merited.

See Lott and Daniel, Term Limits at 11 (cited in note 286) (in constant 1982 dollars, comparing three elections before term limits enacted to three elections after term limits enacted). See also Mark Anderson, Changes on the Way: Preliminary Effects of Term Limits in Arizona, 4:4 Term Limits Outlook Series 9-10 (Nov 1995) (After 1992 passage of term limits, average spending declined from $\$ 17,900$ in 1990 to $\$ 14,500$ in 1994.). 
to vote for incumbents that is not redressed by any effective change in political advertising. Only term limits simultaneously tackle both the collective action and the entry barrier problems.

\section{STRUCTURAL OBJECTIONS TO TERM LIMITS}

Most of the objections to term limits have been arguments for expertise and experience. These have been pitted against the opposite intuition that fresh newcomers would be more principled. ${ }^{310}$ I have little to add to this debate other than to note the inherently unresolvable nature of such disagreements and that neither side does a good job of reconciling itself with voters' simultaneous approval of term limits and votes to retain incumbents. ${ }^{311}$ The voters who approved term limits must have rejected the view of opponents that the loss of expertise and experience is intolerable. The voters who voted to retain incumbents must have been unconvinced by the claim, standing alone, that principled newcomers are better decision makers.

But many arguments against term limits are structural. They argue not that voters are making unwise choices, but that the process of decisionmaking set up by term limits is flawed. I address such arguments next.

\section{A. They're Still Undemocratic}

One response to Parts II and III might be that, even if they show why term limits might be desirable, term limits are still undemocratic. It is important to pin down precisely what might be undemocratic about them. Term limits are, after all, adopted by democratic majorities, and almost always by direct voter ballot. Thus, they reflect at least the views of the current electorate and are not imposed undemocratically on that electorate by its governmental agents. Nor do they raise the traditional concern of restrictions that might interfere with voters' capacity to displace incumbents in the future. If anything, the problem with term limits is that they displace those incumbents too often.

Rather, the critique boils down to three concerns. First, term limits might allow the views of the current electorate to interfere with a future electorate's preference to retain its incumbents. ${ }^{312}$ Second, term limits might allow a state or national majority to impose its views on contrary districts that would prefer to retain

\footnotetext{
${ }^{310}$ See text accompanying notes 10-11.

"See text accompanying notes 12-13.

${ }^{312}$ See, for example, Nelson W. Polsby, Some Arguments Against Congressional Term Limitations, 16 Harv J L \& Pub Pol 101, 104 (1993).
} 
their incumbents. Third, accurately reflecting an electorate's preferences may not advance Burkean conceptions of representative democracy.

\section{The interference with future retention.}

Term limits undeniably might interfere with the preferences of a future electorate to retain its incumbents. If the theory of term limits were that the preferences of current electorates should prevail over the preferences of future electorates regarding their future representation, then term limits would clearly be undemocratic. ${ }^{313}$ But this is not their theory rightly understood.

What the analysis in Parts II and III shows is that we cannot choose a system that leaves the preferences of the future electorate unconstrained. If term limits are not adopted, the future electorate's democratic choices will be coerced by collective action problems and constrained by entry barriers. The collective action problems can cause voters to keep incumbents who have divergent ideological views and provide excessive pork. Term limits can thus help the future electorate choose representatives who better represent their democratic preferences on ideological and pork matters. And entry barriers can exclude preferable candidates from the ballot and allow incumbents to avoid issue definition and shifts in position that bring them closer to electorate preferences. Lowering those entry barriers can thus produce representatives who better fit the democratic preferences of the future electorate.

Granted, this lessened coercion and constraint comes at a cost. Term limits may sometimes preclude the candidacy of an incumbent who a completely unconstrained and uncoerced electorate would prefer to keep. But if we have to choose between a capacity to displace and a capacity to retain incumbents, it seems plain that preserving the latter is less important. Reducing voter

\footnotetext{
${ }^{313}$ See Parts I.A.3, I.B.1, and I.B.2. To be sure, individuals use their present autonomy to constrain their future autonomy all the time. We can, for example, imagine an individual simultaneously eating a rich dessert and signing up to join a weight-watching program. But there are limits to our willingness to allow individuals to legally bind their future selves. I may owe the program money if I fail to show up but I cannot legally have my future self enjoined or imprisoned to make sure he stays on the diet. See generally Einer Elhauge, Allocating Health Care Morally, 82 Cal L Rev 1449, 1527-28 (1994); Thomas C. Schelling, Choice and Consequence 96-99 (Harvard 1984). In any event, allowing the present to bind the future in that case is more justifiable because the individual seeks to bind himself to the weight-watching program. Here, such a theory of term limits would mean a current electorate seeks to bind future electorates who to some extent will consist of different individuals entirely (as persons move, die, and register to vote), and the current majority coalition seeks to bind a future majority that almost certainly will include different persons as coalitions shift.
} 
capacity to retain incumbents matters only if the incumbent is uniquely good at representing the electorate. In districts averaging 572,000 persons, ${ }^{314}$ and states of up to 30 million residents, this seems implausible. The supply of potential candidates is large enough that someone else will almost always exist who shares the same views and ability as the terminated incumbent, or at least the falloff to the second best representative is unlikely to be large. In contrast, a regime that makes it hard to displace incumbents matters as long as any of the many alternatives would be preferable. And the dropoff between the views and ability of the best candidate and the entrenched incumbent can be enormous since the incumbent can be far below the second best option in the jurisdiction.

Certainly this calls for some tradeoff. It may even be that the right tradeoff today is different than the right tradeoff two hundred years ago. Back then smaller populations meant a smaller supply of candidates and perhaps a sharper dropoff to the second best representative. Further, in that era, lower tenure, pork levels, and brandname advantages meant less coercive pressure and lower entry barrier levels. But the key point is that the tradeoff is between different antidemocratic effects. We cannot dismiss a voting regime by noting it has undemocratic effects. We can only optimize by choosing the voting regime that minimizes overall antidemocratic consequences.

Moreover, the constraint that term limits impose on future electorates is not that large for they may always repeal term limits if they like. Almost all term limits are imposed by voter initiative, and a simple majority in a future voter initiative would suffice to lift them. ${ }^{315}$ Thus, if a future electorate arrived at a different view of the tradeoff between constraints on its ability to displace and retain incumbents, it could always release itself from the shackles of the view held by the past electorate. In this respect, ironically enough, the Supreme Court's decision forcing congressional term limits to be imposed via constitutional amendment makes them more antidemocratic because a future majority would not be able to repeal constitutionally imposed term limits.

\footnotetext{
${ }^{34}$ See Will, Restoration at 57 (cited in note 10).

${ }^{315}$ In some states, bans on successive initiatives on the same subject matter require some waiting period before a prior initiative can be repealed, but these are usually not too long. See Referendum Comm of Hermosa Beach $v$ City of Hermosa Beach, 184 Cal App 3d 152, 229 Cal Rptr 51, 54 (2d Dist 1986) (one-year waiting period).
} 
2. The interference with individual districts.

The other concern is not about the past restraining the future, but about the whole restraining the part. For example, a state electorate's decision in favor of term limits may interfere with an individual district's democratic preference in favor of keeping its incumbent in office. ${ }^{316}$

It is important to recognize that this problem is not raised every time an individual district would, absent term limits, retain its representative. The collective action problems identified in Part II mean that every district might, absent term limits, prefer to keep its incumbent. Nonetheless, each of those districts may prefer term limits because it prefers the representation it gets with limits to the representation it gets without limits. Likewise, the entry barriers described in Part III may mean every district prefers its incumbent to the available challengers but would still be better off with lower barriers and new entry.

Still, it cannot be gainsaid that sometimes the problem is raised. In particular, as Part II.C.1 noted, some districts rationally oppose term limits because of a combination of high seniority, low ideological interest, high valuation of pork benefits, and low share of pork costs. The number of such districts may not be large. And, again, the democratic cost is unlikely to be large since term limits only preclude one candidate and there is no reason to expect the next best alternative to be much worse. Nonetheless, such a district's democratic preference in favor of retaining its incumbent is thwarted to further the democratic preferences of the state electorate as a whole.

But this is not unusual. A political jurisdiction generally can enact legislation to further the substantive interests of the jurisdiction's majority even though that conflicts with the preferences of particular regions in the jurisdiction. That is inherent in the supremacy of state law over municipal law, and of federal law over state law. And it is particularly justifiable where, as here, the rationale for imposing the views of the whole on the part is that the part is imposing externalities on other regions. ${ }^{317}$

Indeed, there is nothing in the Constitution that requires states to allow voters to vote by district for its federal representatives. The Constitution requires only that each state sends a number of representatives to the House proportionate to its population. ${ }^{318}$ It is perfectly constitutional for each state to hold a

\footnotetext{
${ }^{30}$ See, for example, Bates $v$ Jones, 904 F Supp 1080, 1095 (N D Cal 1995).

${ }^{313}$ See Part II.C.1.

${ }^{33 \times}$ US Const, Art I, § 2, cl 3; US Const, Art I, § 4; US Const, Amend XIV, § 2.
} 
statewide vote for all its representatives and the framers fully expected many to do so. ${ }^{319}$ Only seven of the original thirteen states initially decided to divide into districts that would each vote for its own representative. ${ }^{320}$ If the state's electorate could constitutionally impose its views about the identity of each representative on individual districts, it surely can constitutionally impose the less restrictive alternative of limiting each representative's terms.

\section{The interference with Burkean representative} democracy.

A more fundamental objection challenges my very definition of democracy: We do not, the argument goes, want a system where each representative slavishly follows the latest poll reflecting the uninformed and undeliberative views of the electorate. Rather, we want and have a system of representative democracy, where voters do not directly vote on issues but rather select a representative to gather information, deliberate and do what the representative thinks is right even if that conflicts with opinion poll evidence of electorate wishes. Under this Burkean conception of representative democracy, the last step of the argument goes, ideological slack might seem good and its reduction by term limits thus undesirable.

But this last step is a false one. Even a Burkean conception of democracy must ultimately rest on the conclusion that it somehow makes voters better off. That is, were we about to enter into a social contract, we would realize that our own uninformed decisions on future issues would produce worse decisionsdecisions less reflective of our true values and preferences-than decisionmaking by representatives with time to make informed judgments on our behalf. Thus, direct democracy could be expected to produce decisions that less accurately reflect the electorate's considered preferences than representative democracy if those representatives comply with a Burkean duty to act as a trustee of the electorate's interests. Elections should instead be about voting for the best Burkean decisionmakers.

There is nothing in this theory that undermines term limits or supports the current system's effective penalty on ousting senior representatives. If electorates want Burkean legislators,

\footnotetext{
${ }^{319}$ See US Term Limits, $115 \mathrm{~S}$ Ct at 1903 \& $\mathrm{n} 30$ (Thomas dissenting). The state power to elect at-large representatives was ended by statute in 1842 . See 5 Stat 1491, codified at 2 USC $\$ 2$ (c) (1994) (requiring all House elections to be held by district). But the constitutional point remains valid.

${ }^{32}$ US Term Limits, $115 \mathrm{~S}$ Ct at 1903 (Thomas dissenting).
} 
they can continue to vote for them under term limits and they have incentives to do so since such legislators on balance produce better representation. Indeed, they are freer to do so with term limits because term limits lower the penalty for ousting senior representatives who may be far worse Burkean decisionmakers than their opponents. Since this penalty applies irrespective of how the senior representatives vote, it does nothing to assure that the representatives behave in a more Burkean fashion. Indeed, one of the major arguments by term limits proponents is that current legislators are far too prone to be nothing more than glorified poll-watchers and that fresh legislators would be more likely to engage in true Burkean representative democratic decisionmaking. ${ }^{321}$

In addition, the theory does not show that the sort of ideological slack reduced by term limits is good. An electorate may want a Burkean legislator, but that is because it wants someone who does not follow uninformed polls on each individual issue, not because it wants someone who deviates from the ideological views of the electorate. An electorate may well be better represented by someone who shares the electorate's ideological views and promises to make an informed judgment over particular issues that arise than they would be by someone who promises, in Perotian fashion, to have an electronic town meeting to make each future decision. But a penalty of diminished power for ousting incumbents can produce incumbents who have different aspirations than the electorate. Such incumbents need not use their ideological slack to fulfill their duty to act as trustee for the electorate's interests and views-they can pursue more venal goals or ideological views at odds with any considered judgment the electorate would reach. ${ }^{322}$

${ }^{321}$ See, for example, Will, Restoration at 99-101, 107-17, 142-45 (cited in note 10); Michael J. Malbin and Gerald Benjamin, Legislatures After Term Limits, in Benjamin and Malbin, eds, Limiting Legislative Terms 209, 211 (cited in note 5); Amihai Glazer and Martin P. Wattenberg, How Will Term Limits Affect Legislative Work?, in Grofman, ed, Legislative Term Limits 37, 40-41 (cited in note 5). If following short-term polls confers an electoral advantage, as it must to conflict with Burkean decisionmaking, then senior incumbents have strong incentives to follow them because doing so maximizes their ideological slack, which they can use to pursue their own views or interests on other matters. Having more ideological slack does not mean one is more likely to use it in a Burkean manner.

${ }^{32}$ Under another use of the term, a "Burkean" legislator also pursues whatever policies he paternalistically regards as in the electorate's best interests even if that conflicts with what he believes the electorate would think if it were fully informed. See Michael E. Levine and Jennifer L. Forrence, Regulatory Capture, Public Interest, and the Public Agenda: Toward a Synthesis, 6 J L Econ \& Org 167, 177 (Special Issue 1990). The attractiveness of this seems dubious, and to call it "democratic" seems more dubious still. But even if valid, such a theory must rest on the premise that the Burkean legislator is some- 
There are also more specific problems with the argument that term limits are bad because they reduce ideological slack. First, even the most extreme Burkean agrees that representatives should face reelection and thus be somewhat politically accountable. They thus implicitly advocate some tradeoff between ideological slack and political accountability. But what is it about the mix of slack and accountability without term limits that would lead anyone to conclude it was optimal? Unless the objection to term limits rests solely on an unjustified bias for the status quo, it must explain what makes the current tradeoff between ideological slack and political accountability optimal. And such an explanation is never provided. ${ }^{323}$ Second, if we want legislators with more ideological slack, it is not at all clear why we should want that advantage conferred in proportion to each district's seniority. Why should some districts get the right degree of slack and not others? A more equitable solution would be to advocate longer terms and fewer elections for all representatives, thus conferring more ideological slack equally on all districts. ${ }^{324}$ Third, the Constitution already makes a judgment about how often to hold elections and thus implicitly makes the tradeoff between slack and accountability. Senators get more slack than Representatives, but neither gets ten-year or lifetime terms, which would confer even more slack. By reducing the ideological slack allowable at elections, term limits simply help make those

how a "better" decisionmaker than an informed polity would be. It thus does not counsel against term limits because there is no reason to think that without term limits such "better" decisionmakers would be selected (their selection may be penalized) or that the increased ideological slack would be used to make "better" decisions (it may be used to make even worse ones than an informed polity would). Such a Burkean theory also suffers from all the problems mentioned in the next textual paragraph.

${ }^{32}$ Likewise, opponents often argue that term limits would shift political power from Congress to the President. This assertion seems highly debatable. A term-limited Congress need not be weaker in battles with the President and may even be tougher because it is likely to be both (1) less focused on preserving scraps of pork and (2) more tightly bound by districts' ideological demands that may force legislators to do battle. But the more fundamental problem is that opponents making this argument never explain precisely what it is about the current balance of legislative and executive power that leads them to believe we are now at the optimal point. Surely it is not because it reflects the original constitutional understanding, because since then we have added term limits for the President but not Congress. Nor, even if we focus solely on experience (as opponents generally do), do term limits appear to result in a mismatch. Under six-to-twelve-year term limits, the average legislator would still sit longer than the average president and much longer than the average cabinet member. Instead, this argument also seems to rest on the unjustified premise that deviating from the status quo is bad.

${ }^{324}$ Empirical studies show legislators' ideological slack shrinks significantly as elections approach. See Kalt and Zupan, $33 \mathrm{~J} \mathrm{~L} \mathrm{\&} \mathrm{Econ} \mathrm{at} \mathrm{126-27} \mathrm{(cited} \mathrm{in} \mathrm{note} \mathrm{145);} \mathrm{Levitt,}$ 86 Am Econ Rev at 435-36 (cited in note 146); Joseph P. Kalt and Mark A. Zupan, Capture and Ideology in the Economic Theory of Politics, 74 Am Econ Rev 279, 298 (1984). 
elections more effective and thus better reflect the tradeoff implicit in the Constitution.

More generally, I see little reason to believe that ideological slack is on balance desirable. We can all recall profile-in-courage cases where the use of slack seems desirable. But history also evidences plenty of profiles-in-evil. There is no a priori reason to believe slack is more likely to be exercised desirably than undesirably. True, we might think of a historically contingent reason. The current long-term incumbents tend (tended?) to be more liberal than the current electorate, first elected when old-fashioned liberalism was more popular. To the extent they are (were?) exercising their slack to further liberal goals, and one likes those goals, then the slack would be desirable. But that would only be persuasive to those who share those liberal views and are willing to see them imposed against the will of the majority. (This may be yet another reason why term limits have been more popular with conservatives than liberals.) And the persuasiveness would vanish with any reversal in the relative political ideologies of senior incumbents and the electorate.

Finally, we must remember that the constitutional question turns on whether the voters imposing term limits were furthering an impermissible democratic objective, not just an objective on which reasonable people might differ. Even if one could make an argument that having Burkean representatives with more ideological slack would be desirable, nothing in that argument explains why voters should not be free to reject that Burkean argument and adopt an electoral system producing representatives with less ideological slack. Seeking to make representatives more accurately represent their electorates may not strike everyone as desirable but it surely is not an unconstitutional objective.

\section{B. They Increase Interest Group Influence}

Disgust with interest group influence was a major impetus to the term limits movement. ${ }^{325}$ But opponents argue that term limits perversely increase, not decrease, interest group influence ${ }^{326}$ To analyze these claims, we must first understand the logic behind public choice theory's prediction that interest groups will have disproportionate political influence. 


\section{Interest group theory.}

One of the puzzles of democracy is that the majority often loses, even when it has a larger stake in the matter. A smaller group with less aggregate interest in an issue can nonetheless beat a larger group with a greater aggregate interest. Oil producers might, for example, get an inefficient government subsidy even though they are outnumbered by the taxpayers who pay for it. Public choice theory explains this phenomenon by noting that all groups affected by legislation face a collective action problem in political effort, which small interest groups are generally better able to overcome.

Obtaining favorable political outcomes requires significant contributions of time, money, and effort. ${ }^{327}$ The most obvious are campaign contributions, which can take the form of money, supportive advertising, or volunteer help. These can not only help influence who gets elected but also cause politicians to modify their views. But even if such campaign contributions were banned, political participation would be costly. It is costly to monitor and lobby legislatures and regulators, to evaluate the positive and negative consequences of their actions, and to communicate this information to lawmakers and citizens. Further, it is costly (in time and effort) for those citizens to absorb the information and then act on it by voting, protesting, writing their representative, or showing up at hearings. The more complex and technical the issue, or the lower the preexisting level of voter knowledge, the higher the information costs of political participation will be. For convenience, I will call both the making of monetary campaign contributions and the expenditure of time, money, and effort to engage in informed political participation making a "contribution" to the group's political effort.

For several reasons, the individual benefits of making contributions to a group's political effort are often slight even though the group's stake is large. To begin with, because the benefits of favorably resolving a political issue are spread among the members of the benefited group, the benefits can be low for each individual group member even though they are high for the group collectively. In addition, each individual has an incentive to free ride on the contributions of other group members since an individual's failure to contribute will not exclude him from whatever collective benefits flow from obtaining or defeating a given governmental action. Moreover, the likelihood that any particular individual's contribution will affect the outcome is minuscule.

\footnotetext{
${ }^{327}$ See generally Elhauge, 101 Yale L J at 36 (cited in note 79).
} 
Accordingly, the majority will often remain rationally ignorant and apathetic because the costs of informed political participation exceed the personal benefits.

Special interest groups have several political advantages over the general public. First, while the general public is large and diffusely interested in many issues, special interest groups are typically small and intensely interested in a limited set of issues. Their members' intense interest means that, for that set of issues, their members derive greater individual benefit from successful group efforts to influence the political process. This makes it more likely that per capita benefits will exceed the individual costs of making a contribution to the group's political effort. It also gives their members less incentive to free ride on other members' contributions, particularly when coupled with a small group size that makes it easier for other members to notice whether individual members have failed to contribute to the group's political activities. ${ }^{328}$

Second, special interest groups face lower costs in organizing and enforcing collective agreements to police free riding. ${ }^{329}$ Their small size makes it easier to identify others who have coinciding interests and to reach collective agreements to share costs by, for example, requiring all members to contribute yearly dues to fund permanent staff or to take turns giving testimony, sending telegrams, or making campaign contributions. It also means that free riding will be easier to detect because it has a proportionally larger effect and because members of small groups are more likely to have ongoing personal contact.

Third, special interest groups often face lower information costs. Monitoring is less costly because special interest groups are, by definition, only concerned with monitoring a limited set of issues. Perhaps more important, their members already have expertise or day-to-day involvement in the matter at hand. This makes it easier for their members to absorb and act on information about potential governmental action. Oil producers are, for

${ }^{32 x}$ Small, intensely interested groups are less susceptible to free riding in three different senses. See id at 36-39 \& nn 24-26. First, they are more likely to have individual members who benefit enough from favorable governmental decisions to have an independent motive to make contributions furthering the group's political goals. Second, they are more likely to have members who are sufficiently large in relation to the size of the group that they have interdependent motives to contribute because their failure to do so would be noticed by other members, who would respond by withdrawing their own contributions. Third, where an incentive to free ride does exist, it is likely to be lower because the divergence between the costs and benefits of contributing to group efforts will be lower, meaning that the expected penalty necessary to curb free riding will be lower as well.

${ }^{*}$ Id at $38-39,40 \mathrm{n} 35$. 
example, likely to have little difficulty judging whether a new oil refining regulation is likely to benefit them or not; members of the general public will have much more difficulty because they are less familiar with how the oil industry works.

To be sure, even special interest groups are large enough to face massive collective action problems. This explains why government expenditures are 1250 to 2500 times larger than the campaign contributions made to influence those expenditures. ${ }^{330}$ But what determines political outcomes is relative political influence, and groups that make some political contributions can thus beat larger groups that deliver none.

2. Term limits' ambiguous effect on interest group influence over candidates.

Term limits proponents have not done a good job explaining precisely why they believe limits on terms would lessen interest group influence. The tendency has been to note all sorts of seemingly inefficient government spending and regulation and then to assert that term limits would reduce it. ${ }^{331}$ But these claims fail to distinguish between governmental inefficiencies caused by interest group influence and those caused by district collective action and entry barrier problems. To some extent, the problem is that the argument about interest group influence overlaps claims already discussed in Parts II and III. We thus

\footnotetext{
${ }^{350}$ See John R. Lott, Jr., A Simple Explanation for Why Campaign Expenditures are Increasing: The Government is Getting Bigger 25 (Mar 26, 1996 draft on file with U Chi I Rev) (puzzling about "[w]hy are Federal budget expenditures 2500 times larger than total Federal legislative campaign expenditures and State budget expenditures 1250 times larger than total state legislative campaign expenditures?").

${ }^{331}$ See, for example, Will, Restoration at 17-36 (cited in note 10). One frequently-made argument is that, even if we do not know why term limits would reduce interest group influence, they must reduce it because interest groups typically lobby against term limits. See, for example, Reed and Schansberg, 76 Soc Sci $Q$ at 711 (cited in note 131). See also Olson, Term Limits Fail, in Benjamin and Malbin, eds, Limiting Legislative Terms at 76, 86-89 (cited in note 5) (detailing that in Washington term limits had only one interest group supporter who provided only 1 percent of all funding while the opposition's support came almost entirely from interest groups). This revealed preference argument is interesting but unpersuasive on its own. Interest groups have made large sunk investments in influencing the current set of incumbents. They can be expected to lobby against any change that reduces the value of those past investments even if the groups would continue to have an advantage in influencing new legislators that is as large or larger than before the change. See also Copeland, Political Careers in Oklahoma, in Benjamin and Malbin, eds, Limiting Legislative Terms at 154 (cited in note 272) (noting that "lobbyists see the task of influencing legislators becoming less efficient but more effective under term limits"). See also Elizabeth A. Capell, The Impact of Term Limits on the California Legislature: An Interest Group Perspective, in Grofman, ed, Legislative Term Limits 67, 81 (cited in note 5) (lobbyist concluding that influencing legislators will become less efficient).
} 
need to identify and exclude this overlap to see whether anything remains to the argument other than the points already discussed.

Sometimes a particular interest group's interests coincide with the interests of a district. Thus, federal subsidies for mohair production both reflected the disproportionate influence of mohair producers in all districts and the disproportionate benefit of such subsidies in certain districts where production was concentrated. ${ }^{332}$ Where the product of interest group influence disproportionately benefits a district in a way that makes district benefits exceed district costs even though national costs exceed national benefits, it fits within my definition of "pork." We can thus expect this to be reduced by term limits for the reasons already covered in Part II. But there is no general reason to expect interest group capture to fit or be explained by pork barrel politics. And if it fit, that would add nothing to the explanation already offered in Part II. Let's thus exclude cases of pork.

Relatedly, the current incidence of interest group influence might bear on the proportion of nonpork one believes is undesirable. Suppose one believes that legislation favoring interest groups is undesirable and that most nonpork is interest group legislation. Then a person who believes that decreasing average tenure decreases overall nonpork levels would find term limits desirable in part because most of the nonpork decreased was undesirable. But this benefit of term limits comes solely from the implications of this belief about the overall desirability of nonpork, which I have already discussed in Part II.B.3. It is not a claim that term limits selectively decrease interest group influence compared to other influences.

A selective discouragement claim is made by term limits proponents who argue that legislative service results in legislators more likely to favor interest groups. For example, legislative service might be viewed as affirmatively indoctrinating or corrupting, undermining the common sense or moral principles that would otherwise lead legislators to fend off interest groups. ${ }^{333} \mathrm{Al}-$ ternatively, one might think that those who enjoy making government transfers are more likely to want to stay in office while. those who do not are more likely to want to leave. ${ }^{334}$ But others have the opposite intuition. They argue that because term-

\footnotetext{
${ }^{372}$ See, for example, Will, Restoration at 23 (cited in note 10 ).

${ }^{300}$ See, for example, James L. Payne, Why Government Spending Grows: The "Socialization" Hypothesis, 44 W Pol Q 487, 487-89 (1991); Mark P. Petracca, Term Limits Will Put an End to Permanent Government by Incumbents, Pub Affairs 8, 8 (Nov 1990).

Is I am indebted to John Lott for this point.
} 
limited legislators will on average be less experienced and expert, they will be more dependent on interest groups for information and expertise about the subject matters being regulated and thus more easily bamboozled. ${ }^{335}$

Such conflicting claims are hard to evaluate. But the more important point is that, to the extent term limits proponents are right, this is merely a subspecies of ideological slack. If senior legislators favor interest groups more than the electorate would like, the electorate could just vote them out of office absent the collective action and entry barrier problems discussed in Parts II and III. And while those collective action and entry barrier problems do provide senior legislators some freedom to favor interest groups in ways the electorate disfavors, that freedom must be traded off against other ways of exploiting ideological slack. A legislator who has a greater propensity to offend his electorate by favoring interest groups can deviate less on other issues from his electorate's wishes. The reasons why term limits might generally decrease ideological slack, whether or not the issue involves interest groups, have already been covered in Parts II and III.

However, there may be some grounds for thinking that term limits can change the direction in which ideological slack is exercised. Suppose that, no matter what their seniority, individuals would have to transgress internal moral principles if they favored special interest groups, which would cause them to suffer some psychological cost. Even if this psychological cost were the same for both senior and junior legislators, that cost might be worth bearing in exchange for a long legislative career but not for a short one. By shortening legislative careers, term limits thus reduce the potential personal benefits of favoring special interest groups. Simply voting out senior incumbents cannot accomplish the same goal, because legislators would still look to the prospective benefit of a long legislative career unless it is categorically denied. But again, any lessening of ideological slack in the direction of interest groups would predictably be offset by increased (and no less damaging) ideological slack in other directions unless the overall amount of ideological slack were somehow reduced. The net benefit of term limits would thus still come from decreased ideological slack along the lines described in Parts II and III.

No, the main sense in which interest group theory might add something to the previous discussion is to explain changes in which preferences the electorate expresses. Interest group theory

${ }^{33 s}$ See Polsby, Am Prospect at $42-43$ (cited in note 5). 
is, after all, a theory about the political participation and voting behavior that electorates actually manifest. Thus, an increase in interest group influence might cause the electorate to express different preferences than it would otherwise. And if this were viewed as undesirable, curbing interest group influence would result in the electorate expressing better preferences. This would improve social welfare even if the legislator's ideological slack from the electorate's expressed preferences were unchanged and overall pork levels were unaffected.

But there is little reason to think term limits would decrease interest group influence in this manner. The factors that make interest group influence disproportionate would persist with term limits. Special interest groups would still have the advantages of fewer free rider problems and lower organizational and information costs. They would still be able to deliver a disproportionate share of campaign contributions, lobbying, and informed voting. This would give candidates (whether newcomers or incumbents) running under term limits just as much incentive to favor interest groups as incumbents running without term limits. And it would give interest groups just as much disproportionate influence over who gets elected as they have now.

Indeed, Nelson Polsby persuasively argues that term limits will increase, not decrease, interest group influence over candidates. ${ }^{336}$ Because incumbents can rely on their ability to deliver governmental benefits and name recognition advantages, newcomers must expend much more money on campaigns than incumbents to get elected. The average winning challenger spends far more than the incumbent. ${ }^{337}$ This makes incumbents less dependent on interest groups for campaign contributions. In effect, Polsby cleverly converts the vice of the current system-senior incumbents' greater insularity from political pressures-into a virtue because it makes them less vulnerable to interest group pressures.

This argument seems descriptively accurate. The greater clout and brandname advantages that give senior representatives more slack from the electorate's preferences generally should also give them more slack from the portions of the electorate belonging to interest groups. But should we regard this as normatively attractive? The shielding from interest group influence is, after all, purchased only at the cost of generally shielding the politician from the influence of his electorate generally. In-

\footnotetext{
${ }^{306}$ Id.

${ }^{35}$ See text accompanying note 305 .
} 
terest group theory explains various distortions in the political process but provides no reason to think the distortions would be smaller with no political accountability at all..$^{338}$

Moreover, one of the costs of a system that makes incumbents independent is that it insulates them from their parties as well. Under our current system, individual legislators treat party performance as a collective good. ${ }^{339}$ To each legislator, her electoral chances turn on a combination of her party's national performance (especially in the Presidency) and her own personal performance. But the individual legislator can have relatively little effect on improving the party's performance, and she benefits from improved party performance whether she contributes to it or not. Thus, legislators focus on improving their individual performance by delivering district pork and on improving their name recognition by raising funds for their own campaigns. If incumbency advantages were reduced by term limits, incumbents might have to rely more on party support in elections, which would improve parties' ability to discipline legislators. This should lessen pork because the party has incentives to take into account the costs of pork to the national economy. ${ }^{340}$ It should also lower voters' information costs in ascertaining legislative positions because party platforms are fewer and more salient than a myriad of position papers by individual legislators.

Even if we put aside the decreased fit with the party and the rest of the electorate's preferences, it is hardly clear that a politician following his own ideological preferences is more desirable than one who follows the preferences of interest groups. First, we can condemn interest group influence as disproportionate only if we have some normative baseline for determining what degree of influence is "proportionate" to the group's interest. ${ }^{341} \mathrm{We}$ do not

\footnotetext{
${ }^{338}$ Compare Elhauge, 101 Yale L J at 83-84, 86-87 (cited in note 79).

${ }^{309}$ See Mayhew, Congress at 30-32 (cited in note 255).

${ }^{30}$ Lessen, but not eliminate, pork because parties still have incentives to provide particularized benefits to districts (like to any interest group) because those benefits are more concentrated and noticeable than the diffuse costs. See Parts II.B.3; IV.B.1. See also Carey, Term Limits in Costa Rica, in Grofman, ed, Legislative Term Limits at 328-32 (cited in note 132) (noting that even under proportional representation system in Costa Rica, parties organize at-large deputies to provide particularized benefits to sub-areas for political gain). But while the costs are less noticeable, they are not entirely externalized the way they are when an individual legislator gets pork enacted and inflicts costs on districts in which he does not run. A party thus suffers costs from excess pork. See id at 33233,336 (finding that providing more pork is correlated with reductions both (1) in votes for the party as a whole and (2) in the chances of post-legislative appointment by the party).

${ }^{31}$ For my full argument on this point, see Elhauge, 101 Yale L J at $48-66$ (cited in note 79).
} 
always want a group's influence to be proportionate to its numbers-consider a racial minority opposing racist legislation or a landowner opposing an uncompensated taking. To say instead that we want each group's influence to be proportionate to its economic stake in an issue is the same as judging all legislation by its economic efficiency. And any alternative measure of what we want group influence to be proportionate to (for example, the group's utility or how far it falls below an egalitarian wealth distribution) is also the same as applying that normative baseline to the legislation. We have no assurance that politically insulated legislators will apply the normative baselines we prefer.

Second, diminishing interest group influence neither magically solves the collective action problems of the general public nor eliminates all potentially distorting sources of political influence. Diminished interest group influence leaves the media with a proportionately greater role, which itself provokes greater efforts to buy media outlets or otherwise influence what the media put out. Moreover, the vast majority of lobbying for government spending is done not by interest groups but by government officials themselves. Thus, one study of witnesses testifying on spending measures found that 1014 of the 1021 witnesses who took a position testified in favor of spending, and 63 percent of all witnesses were government officials. ${ }^{342}$ Even without all the witnesses representing interest groups, these government witnesses would remain. And collective action problems will still prevent large diffuse groups from funding witnesses of their own. It is far from clear that a Leviathan regime, where government officials lobby each other, is preferable to what we have now. At least interest group lobbying keeps the government accountable to some of the interests affected by its decisions.

\section{The Final Period: Problem or Solution?}

Under term limits, legislators would more often find themselves in what they know is their final term, holding legislative office without any prospect of reelection. True, under the current system every legislator eventually reaches his final term too. But he does so less frequently since tenures are longer. Moreover, often he does not know he is in his final term until after he loses an election. Indeed, even the legislator who retires during his fi-

\footnotetext{
${ }^{312}$ See James L. Payne, The congressional brainwashing machine, 100 Pub Interest 1, 4-6 (1990) (47 percent federal bureaucrats, 6 percent other federal legislators, 10 percent state and local officials). Another 33 percent consisted of private institutions receiving government funding. Id at 6 . In addition to the 1,021 testifying for or against the spending bills, 39 witnesses were neutral. Id at 4-6.
} 
nal term must consider his electorate's response during the period of that term before he reaches that retirement decision. The only comparable situation without term limits is that of legislators after they have reached a retirement decision, and such retirements come up less frequently than a final term in a regime of term limits.

Term limits opponents view this as a problem, arguing that it will diminish political accountability. But proponents view it as a helpful solution, arguing that term limits will diminish interest group influence because incumbent legislators will more often be in what they know is their last term and thus need not pander to interest groups for reelection. ${ }^{343}$ Note that this is not a claim about decreased interest group influence over new or incumbent candidates for office, but only about incumbents who are noncandidates because they are in their final period. The claim is also perfectly consistent with the simultaneous votes for term limits and against incumbents. For the only way to obtain this benefit of term limits is to commit to a system where the legislator knows she is entering her last term. Ousting incumbent legislators through ordinary voting will not suffice, for legislators removed from office by losing reelection have just as much incentive to pander to interest groups before their loss as those destined to win reelection.

But the claim faces the same problem as Polsby's general claim that senior incumbents' greater political insulation shields them from interest group influence. ${ }^{344}$ Namely, we have no reason to think that zero political accountability is preferable to distorted political accountability, even when the distortion is allegedly disproportionate interest group influence. Moreover, to the extent that interest group influence takes the form of influencing the information legislators receive, or of influencing which types of persons become legislators, it remains undiminished. Those legislators with ideological views congenial to interest groups are the ones likely to be reelected often enough to reach a final term under term limits, and they are unlikely to change those views all at once.

\footnotetext{
${ }^{3 * 3}$ See, for example, Will, Restoration at 32 (cited in note 10). See also Mills, 10 Pub Affairs $Q$ at 147 (cited in note 115) (same for pork); F.A. Hayek, 3 Law, Legislation, and Liberty 113 (Chicago 1979) (same; advocating a one-term limit with a fifteen-year term).

${ }^{34}$ See text accompanying note 336 . By the same token, a term limits opponent who argues that senior incumbents' greater political insulation without term limits is a virtue because it reduces interest group influence cannot consistently argue that an incumbent's greater political insulation because of more final periods with term limits is a vice.
} 
Indeed, both sides in the last-period debate are undermined by empirical studies showing that retiring legislators do not significantly change their voting behavior and that any changes they do make are similar to changes made by the average legislator running for reelection. ${ }^{345}$ Nor, under presidential term limits, do we see Presidents make notable policy shifts in their second term. Both pieces of evidence suggest that the final period is neither as big a solution nor problem as either side suggests. The lack of political accountability provided by the need to face reelection does not appear to make much difference.

We saw above that there are two possible explanations for how this can be true when ideological slack increases with tenure. ${ }^{346}$ One possibility is that elected officials feel obliged to comply with promises made when running in the election leading to their final term. If so, they would feel equally obligated to carry out the promises they made in the election that got them to their final term under term limits. The other possibility is that by the time they have reached retirement age, politicians have so much ideological slack (because of collective action and entry barrier problems) that they don't have any further to go when the reelection constraint is removed entirely. This degree of slack allows them to vote their own preferences by their penultimate term and leaves them with little desire to change votes when they no longer face reelection. We might accordingly expect a greater final period change under term limits because politicians will reach their final term sooner and thus have less slack in their penultimate term. But that is true only to the extent that senior legislators facing reelection without term limits have an ideological slack problem just as serious as legislators have in their final term under term limits. Better to have that ideological slack exploited for one final term under term limits than for the last decade or so of terms without term limits.

Moreover, under term limits many legislators in their final term would still face political accountability in that they intend to seek another office after they leave the legislature. The Senator who plans to run for President has less incentive to get inefficient pork for his state enacted. For that matter, so does the Senator who wants to be Secretary of the Treasury or otherwise part of the next Administration. Likewise, the Representative who plans to run for Senate, or the state legislator who plans to run for statewide office or a federal office encompassing a larger

${ }^{34}$ See notes 154-55 (collecting sources).
${ }^{345}$ See text accompanying notes $157-65$. 
region, has less incentive to favor pork for her district. This seems entirely salutary. And on issues other than pork, political accountability remains: the legislator in her final period running for higher office has incentives to represent her district accurately to maintain a reputation for accurate representation. Indeed empirical evidence under a non-term-limited system shows that those who leave a legislative seat not to retire but to run for higher office are less likely to diverge ideologically from their electorates than those running for reelection. ${ }^{347}$ Because legislators in their final period under term limits are likely to be younger, they are also more likely to aspire for further office (at least sometime down the road) rather than simple retirement. ${ }^{348}$ Thus, while term limits produce a greater number of final periods, term limits also make a smaller proportion of those in the final period truly unaccountable. Which effect will prove greater is harder to predict $a$ priori.

Finally, it is worth noting that most state-imposed term limits do not impose a final term. They impose a rotation requirement, forcing the incumbent to give up his seat (and thus his seniority and brandname advantage) for a term but do not prohibit him from running again in future terms. Indeed, of the twenty-four states that imposed term limits on their legislators, only seven-Arkansas, California, Louisiana, Missouri, Oregon, North Dakota, and Oklahoma-imposed the sort of absolute term limits that creates this final period problem. Under the other seventeen states' rotation requirement, incumbents forced to leave office would have had incentives to refrain from ideological divergence to preserve their option of running for the seat again in the future.

In any event, a legislator under term limits is less likely to make it to his final term because he is more likely to lose reelection. And he is more politically accountable during the terms he does run. This is another argument for twelve-year House term limits over six-year term limits, since it increases the proportion of years with no final period problem from four in six to ten in twelve. Taking all the above into account, voters could easily con-

${ }^{347}$ See Zupan, 65 Pub Choice at 173-75, 178 \& nn 14, 16, 18 (cited in note 156). See also Lott and Bronars, 76 Pub Choice at 136-43 (cited in note 154); Van Beek, 19 Pub Fin $Q$ at 450-56 (cited in note 155). Zupan does show that such aspiring legislators' divergence increases during their last term, which may indicate that they have already begun to appeal to a larger constituency. Zupan, 65 Pub Choice at 176 (cited in note 156). But that is likely to be socially desirable and in any event the fact remains that the overall divergence for the last two-year term is lower than for legislators running for reelection.

${ }^{343}$ Even without term limits, 42 percent of those retiring from the House of Representatives in 1978 aspired for higher office. Zupan, 65 Pub Choice at 169 (cited in note 156). 
clude that any final period problem is small and outweighed by more accurate representation in nonfinal terms.

\section{The Future Employment Problem}

Term limits may increase the influence of potential future employers on legislators. ${ }^{349}$ Indeed, this problem has been recognized since the time of Alexander Hamilton, who argued against rotation on the grounds that "When a man knows he must quit his station, let his merit be what it may, he will turn his attention chiefly to his own emolument."350

Still, there is reason to think that this effect is small. First, persons who served in the legislature are unlikely to be lacking for jobs. They will make attractive employees whether or not they favored a particular employer.

Second, each legislator only needs one future job. Even if she favors that future employer shamelessly, the magnitude of the divergence from the public interest that this can cause is limited. It is surely small potatoes compared to the divergence possible when a legislator favors all the groups who gave her campaign contributions. And it seems likely to be smaller than the divergence created when collective action problems and entry barriers give incumbents greater ideological slack over the whole range of possible issues.

Third, there are disincentives to hiring legislators who demonstrated past disloyalty to their districts. A person disloyal in a legislative office might also be expected to be disloyal when working for the firm, perhaps to obtain an even better position with the firm's competitors or opponents. A reputation for doing well at one's current job is normally the best recommendation for future employers. Further, the legislators most desirable to hire as lobbyists are often precisely those who opposed the firm's interests when in office. Such former legislators are more likely to be persuasive with their erstwhile legislative allies, who are the ones the firm must win over. ${ }^{351}$ Both effects may negate any incentive for legislators to favor future employers.

Fourth, even if these disincentives were not prohibitive, future employers would face legal and economic obstacles if they tried to exchange job offers for legislative favoritism. Directly offering a quid pro quo would be bribery, punishable with civil and

\footnotetext{
3*: Becker, Bus Wk at 18 (cited in note 5); Polsby, Am Prospect at 43 (cited in note 5).

US Term Limits, 115 S Ct at 1860 (citation omitted).

" 1 See also Glazer and Wattenberg, How Will Term Limits Affect Legislative Work?, in Grofman, ed, Legislative Term Limits at $42-43$ (cited in note 321) (noting evidence that industry hires ex-regulators who were hard on industry).
} 
criminal sanctions. Employers might try to develop a reputation for hiring those who favored them in the legislature. But they would have incentives to renege that make commitment difficult. More important, the employers in an industry seeking favorable legislative treatment would face their own collective action problem. Each has incentives to free ride on other employers' hiring of legislators who favored them in the past.

Fifth, while term limits increase the number of ex-legislators seeking employment, term limits alsa reduce the value of their legislative connections. Under the current system, a retiring legislator may have contacts in the legislature for decades. Under term limits, no contacts can last longer than the term limit period. A legislator leaving office under twelve-year term limits has no contacts after twelve years, and probably no leadership contacts after eight years.

More important, favoring a future employer is just one way of exercising ideological slack. ${ }^{352}$ Even if term-limited legislators have more incentive to favor future employers, senior legislators without term limits have more freedom to do so since they have more total slack. Given the combination of those factors, it is not clear which would in fact favor future employers more. And even if term-limited legislators would favor future employers more, that would not increase the total magnitude of their slack. Such favoritism would have to be compensated by reduced exploitation of slack in other areas. There is little reason to think such a change in how slack is exercised will result in a net harm to the electorate.

In addition, influence by future employers need not be negative. The most important future employer, or at least the one with the fewest collective action problems in offering future employment, is likely to be each official's political party. ${ }^{353}$ To the extent term-limited officials looked to them for employment, that would be expected to increase party discipline. It would also increase officials' motivation to help the party win the next election (and thus have the power to offer government employment). ${ }^{354}$

\footnotetext{
${ }^{352}$ See Levine and Forrence, $6 \mathrm{~J} \mathrm{~L} \mathrm{Econ} \mathrm{\&} \mathrm{Org} \mathrm{at} 179$ (cited in note 322).

${ }^{353}$ In Costa Rica, which has a forty-year history of legislative term limits, 70 percent of interviewed legislators intended to seek further political office and 91 percent of those expected their political parties to secure them a political appointment. Carey, Term Limits in Costa Rica, in Grofman, ed, Legislative Term Limits at 325 (cited in note 132). Forty-six percent of those who served in the Assembly between 1949 and 1986 actually received such appointments. Id at 325-26.

${ }^{35}$ From 1974 to 1990 in Costa Rica, 64 percent of term-limited legislators whose party won the next election got a political appointment immediately following their legislative service; those whose party lost received an appointment less than 1 percent of the time.
} 
Such enhanced party discipline and motivation should have prodemocratic effects. It reduces pork in line with national electorate preferences, and it lowers voter information costs in choosing between candidates. ${ }^{355}$

Finally, the empirical evidence now available does not indicate that the prospect of future employment is a large problem for legislators. A study of legislators who announced their retirement from the legislature found that those planning to take another job with either the government or a private lobbying group did not vote differently than other retiring legislators. ${ }^{356}$ There is little reason to think legislators taking other jobs after term limits would behave any differently.

Voters could thus rationally conclude that the future employment problem has no significant negative net effect on the accuracy of their representation, and is more than offset by the positive effect of term limits. Or they might conclude that any negative effect could be corrected with laws restricting postlegislative work (for as long as their contacts are fresh), just as the United States now restricts employment by those who leave the executive branch.

E. The Short-Term Thinking Problem

Others argue that term limits will increase legislative impatience. ${ }^{357}$ The premise is that legislators are excessively shortterm-oriented because they must run for reelection every two years ${ }^{358}$ In those elections, voters dismiss commitments to future actions and judge the legislator based only on the results she has actually delivered..$^{359}$ The legislator thus favors government projects with short-term returns that she can show before her reelec-

Id at 326-27.

${ }^{355}$ See text accompanying notes $339-41$.

${ }^{*}$ See Lott, 52 Pub Choice at 177-79 (cited in note 154) (deviation from nonretiring congressmen less than 2 percent).

${ }^{s 7}$ See, for example, Cohen and Spitzer, 80 Georgetown L J at 479 (cited in note 251); Malbin and Benjamin, Legislatures After Term Limits, in Benjamin and Malbin, eds, Limiting Legislative Terms at 219 (cited in note 321).

${ }^{3 x}$ See Morris P. Fiorina, Retrospective Voting in American National Elections 25-43 (Yale 1981) (Voters vote based on already-delivered governmental benefits, not those that will be delivered in future because of current governmental programs.); Jeffrey S. Banks, Linda R. Cohen, and Roger G. Noll, The Politics of Commercial R\&D Programs, in Linda R. Cohen and Roger G. Noll, eds, The Technology Pork Barrel 53, 61 (Brookings 1991) (Programs garner more electoral support the earlier the benefits are realized.); Linda $R$. Cohen and Roger G. Noll, The Political Discount Rate (Center for Economic Policy Research Discussion Paper, No 209, 1990).

${ }^{30}$ Cohen and Spitzer, 80 Georgetown L J at 487-88 (cited in note 251). 
tion. Long term projects get rejected even if they have greater present value.

The current advantages of incumbency reduce this tendency to short-termism because they make the incumbent more likely to consider the beneficial effects of government projects in future years. Term limits, on this theory, have three baleful effects. They eliminate the possibility the legislator will consider beneficial effects in years beyond the term limit. They reduce the career benefits of positive effects in years before the term limit because those effects cannot lead to as many potential reelections. Finally, they reduce the consideration the legislator will give to any effects in future years because the reduced incumbency advantage makes the legislator less likely to reach any future term. All will exacerbate the tendency of legislators to be short-term oriented.

This is of course quite similar to the claim that corporate management needs to be protected from corporate takeovers because they make management "too" short-term oriented. The claims suffer from the same defect: it is not at all clear why we should reject whatever discount rate voters and shareholders give to future claimed benefits. They may rationally have different views about the appropriate discount rate to apply to the future generally. Or they may rationally have a lot less confidence than current management/legislators in claims of benefits in future years. If current voters really were confident about a future benefit, they would have no disincentive to vote for a legislator who made it possible.

In any event, there are other problems with the claim. First, the effects on short-termism are somewhat conflicting. Without term limits, a legislator has extra incentives to favor short-term programs in his early terms. Such programs help him win the key early reelections that allow him to attain a level of seniority that for the rest of his career garners him political insulation by causing collective action and entry barrier problems. Even proponents of the theory concede as much. ${ }^{360}$

Second, the current system's supposed benefit of lessened legislative impatience comes at a great cost: incumbents' increased political insulation. ${ }^{361}$ Why should we think the costs of greater political insulation are less than the benefits of greater patience? Politically-insulated legislators may not discount the

\footnotetext{
${ }^{360}$ Id at 491 ("[I]ncumbency advantages exacerbate the tendency to choose short-run programs.").

${ }_{361}$ Id at 492 (arguing that legislative impatience results precisely because term limits increase electoral competitiveness).
} 
future by as much, but they may also pursue goals completely contrary to those of the electorate. A difference in the rate of discounting a common goal seems unlikely to matter as much as difference over what goal to choose.

Most important, this is not an argument that term limits decrease the accuracy with which the electorate's preferences are recorded in elections. It is a claim that term limits increase that accuracy but that those electorate preferences are normatively inappropriate. A rational electorate could well be expected to reject such a claim. Whatever its other merits, nothing in it suggests term limits should be considered undemocratic.

\section{CONCLUSION}

Opponents of term limits generally begin with the strong premise that term limits are undemocratic. Indeed, even supporters often concede as much. ${ }^{362}$ The Supreme Court in US Term Limits was no exception. This Article aims to show this premise is false. There are compelling reasons to believe term limits help the electorate register its political preferences more accurately. Term limits reduce collective action pressures to vote for a senior incumbent to gain a higher share of legislative clout. And term limits lower entry barriers that keep out challengers. Both effects would likely reduce the ideological divergence between electorates and their representatives.

There are, to be sure, some contrary arguments. As Part IV shows, some antidemocratic effects from term limits are possible. But no such negative effect is likely to significantly interfere with the electorate's ability to get accurate representation. I thus conclude that term limits on balance are prodemocratic. Granted, this requires a judgment call not everyone may agree with. But at a minimum we need to ask ourselves where the burden of proof should lie. It seems plain that democratic principles require putting it against those who would interfere with the electorate's democratically expressed wish for term limits. It seems equally plain that this burden has not been carried. But I would go further. The matter seems sufficiently debatable that it should not be left to decision by courts applying a burden of proof at all. Rather, it should be left where we normally leave such contestable matters about how best to organize our society: to the political process.

Of course, the Court realized that, in the name of protecting democracy, it was frustrating the democratic preferences of those

${ }^{* 2}$ See Will, Restoration at 213 (cited in note 10 ). 
who voted for term limits. What it appears not to have realized is that it was also likely interfering with the democratic preferences of future electorates voting in regular elections. Instead, it relegated them to a system that condemns such electorates to ideologically divergent representatives that less accurately reflect the views of the electorate than would have been true with term limits. 


\section{APPENDIX}

I here derive mathematically various points made in Part II about the collective action problems addressed by term limits. Assume throughout a legislature with $n$ districts each of which elects one legislator. The total benefits of distributable governmental action are $B$. The total costs are $C$. Each district $i$ 's share of governmental benefits is $S_{i}$, ranging from 0 to $n$. The average share equals 1 and the sum of the shares equals $n$, that is:

$$
\sum_{i=1}^{i=n} S_{i}=n
$$

$S_{i}$ is an increasing function of the tenure of district $i$ 's representative, and a decreasing function of the average tenure of the other districts. $\phi$ denotes the degree of fit between the ideological views of the district and its representative, with $\phi$ ranging from 0 to 1 . The value of perfect ideological fit is $F$. Variables will be subscripted "tl" for term limits, and "nl" for no term limits.

In the beginning, I also make the following assumptions, which are relaxed later. Seniority affects only the share of governmental benefits and not the ability to advance ideological positions. $B$ and $C$ are constants-that is, I make no claim yet that term limits might affect the total amount of distributable governmental benefits enacted by the legislature. All districts share the costs of governmental benefits equally, thus for each district the costs are $C / n$. Finally, all districts are assumed to attach the same value to ideological fit and to a given governmental benefit.

The value a district enjoys from a representative is

$S i B / n-C / n+\phi F$.

The district will thus vote for its incumbent over a newcomer if:

$S_{\text {(incumbent) }} B / n-C / n+\phi$ (incumbent) $F>S_{\text {(newcomer })} B / n-C / n+\phi($ newcomer) $F$,

that is, if:

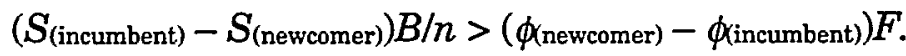

Since the share of pork is an increasing function of tenure, $S_{\text {(incumbent) }}-S_{\text {(newcomer) }}>0$, the incumbent can be reelected even though $\phi$ (newcomer) $-\phi$ (incumbent) $>0$, that is, even if he offers a poorer 
ideological fit than the newcomer. Moreover, $S_{\text {(incumbent) }}-S_{\text {(newcomer) }}$ is larger the longer the incumbent's tenure, so that the magnitude of the permissible ideological gulf between the incumbent and any newcomer, $\phi$ (newcomer) $-\phi$ (incumbent), is also larger the longer the incumbent has served. Longer tenure thus makes $\phi$ (incumbent) lower, indicating larger ideological slack. Also, the larger the total amount of distributable governmental benefits per district, $B / n$, the more pronounced an effect tenure has on ideological slack.

Would these districts be better off with term limits? Suppose first that all districts have incumbents with the same tenure and thus the same share of governmental benefits. Thus for each district, $S=1$. Accordingly, without term limits, each district's utility from representation is $(B-C) / n+\phi$ nl $F$. With term limits covering all districts, ${ }^{363}$ each district's incumbents will be ousted at the same time so that none suffers a disadvantage in benefit distribution, and the district's utility from representation will be $(B-C) / n+\phi(t \mathrm{ll}) F$. Each district thus benefits from term limits as long as $\phi(\mathrm{tl})>\phi(\mathrm{nl})$. Since term limits decrease the tenure of members (to zero at first), and $\phi$ decreases with tenure, $\phi(t 1)>\phi(\mathrm{nl})$. Thus, every district should favor term limits even though every district also favors retaining its incumbent. The degree of enthusiasm for term limits proposals should be higher the longer the tenure of sitting incumbents, and the higher the overall amount of pork, since that decreases $\phi_{(\mathrm{n})}$. The enthusiasm for term limits will also be higher the more value voters put on ideological fit, that is, the higher $F$.

Now suppose we relax the assumption that seniority has no effect on relative legislative clout on ideological issues. Let us call the degree of legislative power $p$, which goes from 0 to 1 and represents the effectiveness of the legislator in getting his ideological views implemented into legislation. To isolate the ideological effect, put aside the effect on the share of governmental benefits. The ideological satisfaction a district will enjoy from a representative will be $p \phi F-p(1-\phi) F$, which is the same as $2 p \phi F-p F$. This is positive as long as $\phi>0.5$. Such an incumbent can beat a rival with a higher $\phi$ even on purely ideological considerations. Suppose a rival's $\phi=1$, indicating 100 percent coincidence with the ideological views of his electorate. Then the incumbent can win on ideology as long as $(2 \phi-1) p_{\text {(incumbent) }} F>p_{\text {(rival) }} F$, that is, as

\footnotetext{
${ }^{3 \infty}$ If the term limits only cover some of the legislative districts, as with state-imposed term limits on its federal legislators, collective action problems would remain. See Part II.D.
} 
long as $(2 \phi-1) p_{\text {(incumbent) }}>p_{\text {(rival). As long as the incumbent's }}$ $\phi>0.5$, a legislator with more $p$ than a newcomer will be able to sustain a lower $\phi$. The lowest sustainable incumbent $\phi$ will be $0.5+\left(p_{\text {(rival) }} / 2 p_{\text {(incumbent) })}\right.$. To illustrate, a legislator with four times as much power on ideological issues as a rival with zero ideological slack could maintain a $\phi$ as low as 0.625 ; with twice as much power one as low as 0.75 ; with 50 percent more power as low as 0.83 .

What if the seniority of representatives varies among districts? Then the question is more complicated. To simplify the analysis, put again to one side the link between seniority and relative clout on ideological issues. Assume districts discount future results, with $D_{t}$ reflecting the extent to which they give present value to a result at future time $t . D_{t}$ is a decreasing function of $t$, and ranges from 1 to 0 . Then the value a district puts on its representation without term limits will be:

$\sum_{t=0}^{t=\infty} D_{t}\left(S_{t(n l)} B / n-C / n+\phi_{t(n l)} F\right)$

Assuming that with term limits each district would expect only average seniority, $S=1$, so that the value of representation with term limits is:

$\sum_{t=0}^{t=\infty} D_{t}\left(B / n-C / n+\phi_{t(t l)} F\right)$

Thus, a district will favor term limits as long as:

$0<\sum_{t=0}^{t=\infty} D_{t}\left(1-S_{t(n l))} B / n+D_{t}\left(\phi(t l)-\phi_{t(n l))} F\right.\right.$

In other words, as long as

$\sum_{t=0}^{t=\infty} n \Delta \phi_{t} F>\sum_{t=0}^{t=\infty}\left(S_{t(n l)}-1\right) B$

where $\Delta \phi_{t}=\phi_{t(\mathrm{t})}-\phi_{t(\mathrm{nl}) .}{ }^{364}$ We know the left side of the equation is positive because $\Delta \phi>0$ for all values of $t .{ }^{365}$ The right side of the

${ }^{364}$ Note that I have assumed the discount rate for future distributable benefits equals 
equation should be negative for any district with lower than average seniority, since $S-1<0$ for low values of $t$ and there is no reason to expect it to be greater than 0 for high values of $t$. Thus, every district with below-average seniority should support term limits. Indeed, they should support term limits even if they put no value on ideological fit $(F=0)$ because they would still benefit from a more even distribution of governmental benefits.

But what if the district's seniority is higher than average? Then the right side of the inequality should be positive, since $S-1>0$ for low values of $t$ and there is no reason to expect it to be lower than 0 for high values of $t$. Still, this does not mean that we should expect a district with a highly senior representative to oppose term limits, for relatively high seniority increases both $S_{t}$ and $\Delta \phi_{t}$ at low values of $t$, thus increasing both sides of the inequality. Districts with highly senior representatives have both larger incentives to favor term limits because they bear larger ideological costs and larger incentives to oppose term limits because they enjoy a greater share of governmental benefits without limits. A district with a senior representative will be more likely to oppose term limits the lower its $F$, meaning it cares relatively little about ideological slack. The level of $B / n$, indicating the level of governmental benefits at stake, has conflicting effects. Increasing $B / n$ increases the magnitude of the seniority effect on the right side of the equation. But it also decreases $\phi(n l)$ by increasing ideological slack. The overall level of governmental benefits thus has no clear effect on whether districts with relatively senior representatives will support or oppose term limits.

However, there is no doubt that all the districts as a whole are better off with term limits even if a few are not. That is because for all districts the relative comparison at any time is whether

$$
\sum_{i=1}^{i=n} S_{i(t l)} B / n-C / n+\phi_{i(t l)} F>\sum_{i=1}^{i=n} S_{i(n l) B} B / n-C / n+\phi_{i(n l)} F
$$

the discount rate for future ideological fit. If the voters discount future distributable benefits more than future ideological fit, term limits are more attractive. If they discount ideology more, term limits are less attractive.

${ }^{3 \infty}$ Even if a district begins with a representative with tenure lower than the term limit (for example, a district with a four-year incumbent considering a twelve-year term limit), its $\phi$ should still be lower with term limits because the declining seniority of other representatives makes the seniority of its representative somewhat less important. See Part II.C.1. 
Since $\sum_{i=1}^{i=n} S_{i}=n$, this is true as long as $\Delta \phi>0$, which we

have already seen to be true. The intuition underlying this is that, over all districts, issues about the distribution of governmental benefits balance out, but the ideological cost of unlimited terms remains.

Now let us consider the effect of seniority on the overall level of governmental activity, some of which is pork and some nonpork. The total benefits of pork are $B_{\text {pork, }}$, the total costs $C_{\text {pork }}$. By definition, $B_{\text {pork }}<C_{\text {pork }}$. Likewise, $B_{\text {nonpork }}$ and $C_{\text {nonpork }}$ denote the benefits and costs of nonpork governmental action. Assume $B_{\text {pork }}$ and $C_{\text {pork }}$ are not constant but are rather increasing functions of the average tenure of representatives in the legislature. Because each incremental expenditure on pork by definition costs more than it benefits, this assumption implies that $C_{p o r k}-B_{p o r k}$ is also an increasing function of average legislative tenure. In contrast, $B_{\text {nonpork }}$ and $C_{\text {nonpork }}$ are assumed to be constants unaffected by average legislative tenure. ${ }^{366}$ The districts as a whole are better off as long as

$$
\begin{aligned}
& \sum_{i=1}^{i=n} S_{i(t l)}\left(B_{\text {pork }(t l)}+B_{\text {nonpork }}\right) / n-\left(C_{\text {pork }(t l)}+C_{\text {nonpork }}\right) / n+\phi_{i(t l)} F> \\
& \sum_{i=1}^{i=n} S_{i(n l)}\left(B_{\text {pork }(n l)}+B_{\text {nonpork }}\right) / n-\left(C_{\text {pork }(n l)}+C_{\text {nonpork }}\right) / n+\phi_{i(n l)} F
\end{aligned}
$$

Since $\sum_{i=1}^{i=n} S_{i}=n$, this is the same as whether:

${ }^{30}$ If lower legislative tenure does lower $B_{\text {nonpork }}$ and $C_{\text {nonpork, }}$ then the effect will be negative to the extent $B_{\text {nonpork }}>C_{\text {nonpork, }}$, and positive to the extent $C_{\text {nonpork }}>B_{\text {nonpork. }}$. The former will be true if most nonpork distributable governmental benefits are socially desirable, the latter if most are undesirable. Compare Part IV.B. Those who find most governmental activity undesirable (i.e., conservatives) are thus particularly likely to find term limits desirable. In any event, the degree of change to $B_{\text {nonpork }}$ and $C_{\text {nonpork }}$ should be smaller than the degree of change to $B_{p o r k}$ and $C_{p o r k}$ for the reasons described in Part II.B.3. Thus, even if the lessened governmental activity is on balance desirable, the greater effect on pork will likely balance it out, especially since all the pork is undesirable and the nonpork is a mixed bag. 
$B_{p o r k(t)}-C_{p o r k(t)}+n \phi_{\text {avg }(t))} F>$

$B_{p o r k(n l)}-C_{p o r k(n l)}+n \phi_{a v g(n l) F}$

where $\phi_{\text {avg }}$ equals the sum of each district's $\phi_{i}$ divided by $n$. That $\phi_{\text {avg }}$ was higher with term limits than without them was already sufficient reason for the political jurisdiction as a whole to be better off with term limits. The additional factor that $B_{\text {pork }}-C_{\text {pork }}$ is also greater (i.e., less negative) with term limits adds another reason. Similarly, if all districts' incumbents have the same tenure, then the effect on pork levels makes term limits even more beneficial for each district.

If seniority varies, the answer again depends on whether the districts have relatively junior or senior representation. Junior districts will benefit even more from term limits because lower overall levels of pork are distributionally favorable to them. Senior districts are again more complicated. They will favor term limits if:

$$
\begin{aligned}
& \sum_{t=0}^{t=\infty} D_{t}\left(\left(B_{p o r k(t l)}+B_{n o n p o r k}\right) / n-\left(C_{p o r k(t l)}+C_{n o n p o r k}\right) / n+\phi_{t(t))} F\right)> \\
& \sum_{t=0}^{t=\infty} D_{t}\left(\left(S_{t(n l)}\left(B_{\text {pork }(n l)}+B_{\text {nonpork }}\right) / n-\left(C_{\text {pork }(n l)}+C_{\text {nonpork }}\right) / n+\phi_{t(n l)} F\right) .\right.
\end{aligned}
$$

That is, if:

$$
\begin{aligned}
& \sum_{t=0}^{t=\infty} n \Delta \phi t F+C_{p o r k(n l)}-C_{p o r k(t l)}> \\
& \sum_{t=0}^{t=\infty} S_{t(n l)} B_{\text {pork }(n l)}-B_{\text {pork }(t l)}+\left(S_{t(n l)}-1\right) B_{\text {nonpork. }}
\end{aligned}
$$

The left side of the equation represents what senior districts have to gain from term limits, lower ideological divergence and pork costs. It is positive, both because $\Delta \phi$ is positive as previously discussed and because $C_{p o r k}$ is higher without term limits than with them. The right side of the equation represents what senior districts have to lose from term limits-their previously higher share of distributable benefits. It is also positive because $S_{t}>1$ for low values of $t$ and $B_{\text {pork }}$ is higher without term limits than with them. If each additional expenditure on pork costs more 
than $S_{t}$ times its benefits, then $C_{p o r k(n l)}-C_{p o r k(t)}$ should be greater than $S_{t(n l)} B_{\text {pork }(n l)}-B_{\text {pork(t }(t)}$ for all values of $t$. In these circumstances, the effect of lowering pork levels will make term limits more attractive to senior districts. Even if additional pork expenditures are less than $S_{t}$ times higher, the senior district may still find the effect of term limits on pork levels beneficial because of the reduced ideological slack valued at $n \Delta \phi_{t} F$. And at higher levels of $t$, the higher incremental costs of pork should make term limits even more attractive despite the district's initially high seniority because $S_{t}$ will over time average 1 . 


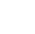

